UNIVERSIDADE DE SÃO PAULO

FACULDADE DE ECONOMIA, ADMINISTRAÇÃO E CONTABILIDADE DEPARTAMENTO DE CONTABILIDADE E ATUÁRIA PROGRAMA DE PÓS-GRADUAÇÃo EM CIÊNCIAS CONTÁBEIS

ESTRATÉGIAS DE INVESTIMENTO EM AÇÕES BASEADAS NA ANÁLISE DE DEMONSTRAÇÕES CONTÁBEIS: É POSSÍVEL PREVER O SUCESSO?

Fernando Caio Galdi

Orientador: Prof. Dr. Alexsandro Broedel Lopes

São Paulo

2008 
Profa. Dra. Suely Vilela

Reitora da Universidade de São Paulo

Prof. Dr. Carlos Roberto Azzoni

Diretor da Faculdade de Economia, Administração e Contabilidade

Prof. Dr. Fábio Frezatti

Chefe do Departamento de Contabilidade e Atuária

Prof. Dr. Gilberto de Andrade Martins

Coordenador do Programa de Pós-Graduação em Ciências Contábeis 


\title{
ESTRATÉGIAS DE INVESTIMENTO EM AÇÕES BASEADAS NA ANÁLISE DE DEMONSTRAÇÕES CONTÁBEIS: É POSSÍVEL PREVER O SUCESSO?
}

\author{
Tese apresentada ao Departamento de \\ Contabilidade e Atuária da Faculdade de \\ Economia, Administração e Contabilidade da \\ Universidade de São Paulo como requisito \\ parcial para a obtenção do título de Doutor em \\ Ciências Contábeis.
}

Orientador: Prof. Dr. Alexsandro Broedel Lopes

\section{SÃo PAULO}


FICHA CATALOGRÁFICA

Elaborada pela Seção de Processamento Técnico do SBD/FEA/USP

Galdi, Fernando Caio

Estratégias de investimento em ações baseadas na análise de demonstrações contábeis: é possível prever o sucesso ? I

Fernando Caio Galdi. - São Paulo, 2008.

$119 \mathrm{p}$.

Tese (Doutorado) - Universidade de São Paulo, 2008 Bibliografia.

1.Balanço contábil 2. Investimentos 3. Governança corporativa I. Universidade de São Paulo. Faculdade de Economia, Administração e Contabilidade. II. Título.

$$
\text { CDD - } 657.3
$$


Ao meu querido avô, Luiz Galdi Júnior (In Memoriam) e aos meus pais, Ronaldo e Valéria. 


\section{Agradecimentos}

Além de muitas horas de trabalho, discussões e reflexões, esta tese é resultado da parceria e amizade que tenho com o Prof. Alexsandro Broedel Lopes. Sua dedicação e comprometimento com o estudo e a pesquisa de contabilidade e finanças me inspiraram a prosseguir na carreira acadêmica.

Agradeço também ao Prof. Eliseu Martins pelas valiosas sugestões em versões preliminares deste trabalho e pela sua incrível dedicação à evolução da contabilidade no Brasil. O Prof. Eliseu serve de modelo e me motiva desde a graduação.

As críticas e sugestões do Prof. Gilberto Martins também contribuíram significativamente para a melhoria deste estudo. O ideal do Prof. Gilberto pela busca da cientificidade na pesquisa em contabilidade tem sido de extrema relevância para a evolução desses trabalhos no Brasil.

Gostaria de salientar, também, as valiosas críticas, sugestões e comentários dos Profs. William Eid e Antonio Lopo Martinez (neste e em outros trabalhos) que contribuíram para a elaboração desta tese.

Agradecimento especial à FAPESP que me apoiou desde o início de minha jornada acadêmica.

Esta tese também se beneficia de valiosas sugestões dos Profs. Bruno Funchal e Fábio Moraes da Costa, que além da amizade, têm me ajudado consideravelmente para a evolução de minha pesquisa.

Importante mencionar também os comentários recebidos do Prof. James Ohlson (em versões preliminares e desdobramentos deste trabalho) no congresso anual da AAA 2007 e no FARS 2008 e do Prof. Stephen Penman, os quais contribuíram para a evolução de minha pesquisa. 
Gostaria de agradecer também aos Profs. Iran Siqueira Lima, Fábio Frezatti e Nelson Carvalho, que em momentos e de formas diferentes contribuíram significativamente para minha formação acadêmica e profissional.

Também tenho dívida com os ensinamentos obtidos junto aos Profs. José Roberto Securato, Heron do Carmo, Vera Lúcia Fava e Naércio Menezes, além dos professores do departamento de contabilidade e atuária da USP com quem tive aula na graduação e na pós-graduação.

Aos colegas Gerlando Lima, Leonel Pereira, Renê Pimentel, Antônio Coelho, Roberta Alencar e Daniel Bergmann pelas frutíferas discussões acadêmicas.

Aos participantes do $54^{\circ}$ Fórum de Discussões Metodológicas do Departamento de Contabilidade e Atuária da FEA-USP, pelas críticas e sugestões.

À Roberta Alves por toda motivação, inspiração, paciência e apoio durante esta jornada.

Finalmente, gostaria de agradecer aos meus pais pelos ensinamentos e pelo esforço realizado para a viabilização deste objetivo. 
"What is a cynic? A man who knows the price of everything and the value of nothing”. Oscar Wilde - Lady Windermere's run 


\section{RESUMO}

Este trabalho investiga a utilidade e as limitações de estratégias de investimento em ações baseadas na análise de demonstrações contábeis. Inicialmente a avaliação é realizada para o conjunto total de empresas listadas na Bovespa. Na seqüência, restringe-se a investigação para os subconjuntos de empresas com alto índice PL/P (proxy de risco) ou/e com baixo BCGI (proxy de governança). De acordo com evidências apresentadas na literatura de contabilidade e finanças conjectura-se que estes grupos possuem características para que as estratégias de investimento baseadas na análise de demonstrações contábeis sejam mais úteis para a discriminação de boas e más oportunidades de investimento. As evidências encontradas apontam para uma maior utilidade da análise de balanços para a seleção de uma carteira de investimento em ações no grupo de empresas com alto PL/P e/ou baixo BCGI. Adicionalmente, incorporam-se nas análises econométricas os fatores de risco que poderiam ter relação com os resultados encontrados. Demonstra-se que a implementação da estratégia é mais realista (em termos de volume financeiro negociado das ações) para o grupo de empresas com baixo BCGI. Entretanto, há uma redução dos retornos obtidos com essa estratégia selecionar empresas fortes financeiramente dentro do grupo de empresas com baixo BCGI em relação à estratégia de seleção de empresas com alto PL/P e com bons indicadores financeiros. Esse resultado é consistente com a relação teórica negativa esperada entre liquidez e retorno e contribuí com a literatura para a explicação da obtenção de retornos anormais com estratégias de investimento baseadas na utilização de análise de demonstrações contábeis. 


\begin{abstract}
This thesis investigates the usefulness and limitations of investment strategies based on financial statement analysis. Initially I assess the usefulness of the strategy for the full sample of Brazilian public-held firms. An additional analysis considers the partition of high book-tomarket $(\mathrm{HBM})$ or/and poor corporate governance $(\mathrm{CG})$ firms. Capital markets research in accounting and finance show evidences that permit one to posit that firms within these groups (HBM and/or poor CG) present specific features that should enhance the usefulness of financial statement analysis as an investment tool. I find evidences that the analyzed strategies significantly differentiate between winners and losers for both groups (HBM and poor CG) but not for the full sample of firms. These results confirm and expand Piotroski's (2000) evidences. Further I consider the possible omitted risk-factors that could explain the results obtained. I show that the practical implementation of the strategy is more realistic (regarding stock's trading volume) if applied for firms with poor corporate governance arrangements when compared to the HBM ones. However, the strategy returns are lower when applied to the subset of poor corporate governance firms. This evidence is consistent with the negative expected relation between liquidity and returns (Bekaert et al, 2006) and contributes to previous research (Piotroski, 2000; Mohanran, 2005) on abnormal returns obtained with financial statements analysis.
\end{abstract}




\section{SUMÁRIO}

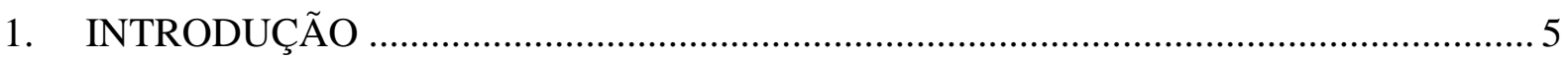

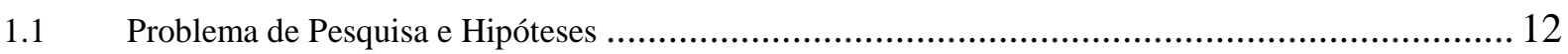

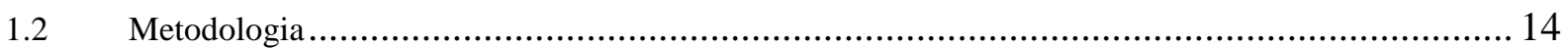

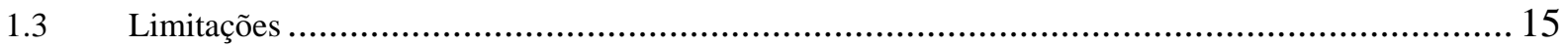

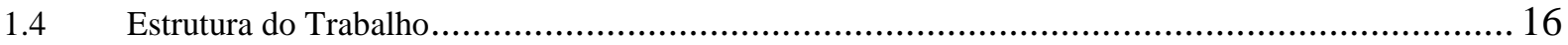

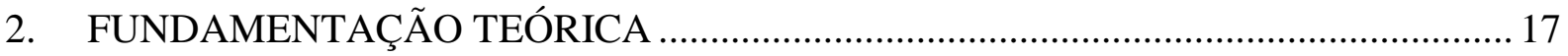

2.1 Informações contábeis, governança e modelos de avaliação de empresas....................................... 19

2.2 Estratégias de Investimento baseadas na Análise de Demonstrações Contábeis .............................. 21

2.2.1 A relevância dos accruals - ajustes advindos do regime de competência ..................................25

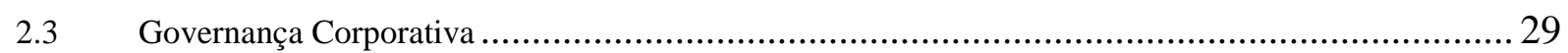

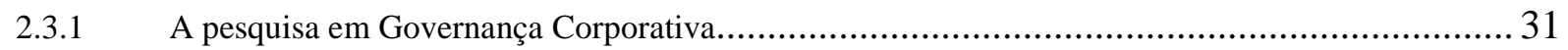

2.3.2 Governança Corporativa e o Valor das empresas ............................................................... 32

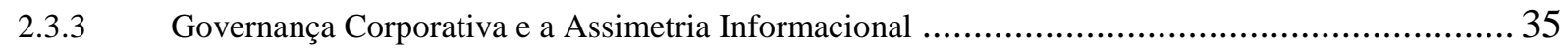

2.3.4 Mercado de Capitais e o modelo contábil brasileiro............................................................... 37

3. MODELANDO A RELAÇÃO ENTRE GOVERNANÇA E PREÇO DAS AÇÕES .... 45

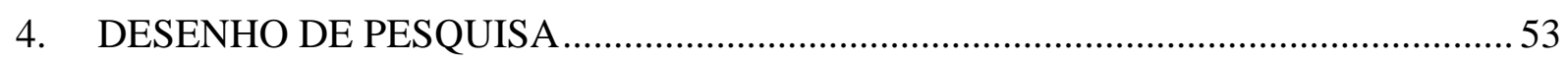

4.1 Sinais financeiros obtidos a partir da análise de demonstrações contábeis ................................... 54

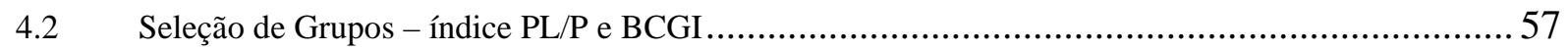

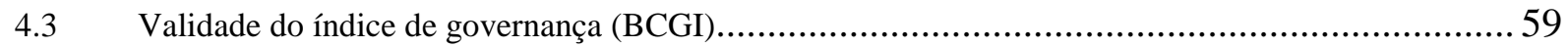

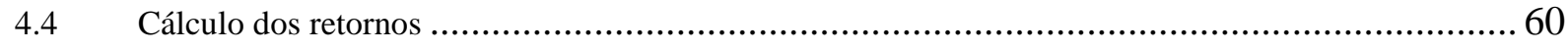

4.5 Técnicas utilizadas para a investigação da utilidade de estratégias de investimento baseadas em

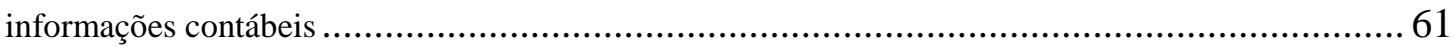

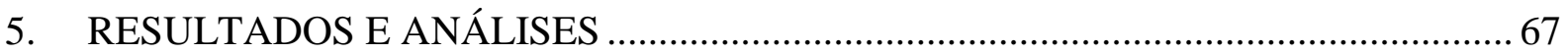

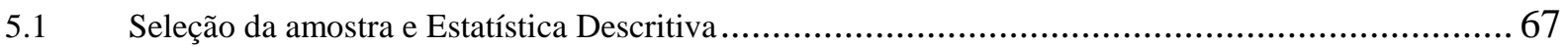

5.2 Associação entre o $B r F \_S C O R E$ e os retornos futuros …....................................................... 71

5.3 Utilidade da estratégia de investimentos baseada em informações contábeis.................................. 80

5.4 Utilidade da estratégia de investimentos baseada em informações contábeis para as empresas com alto

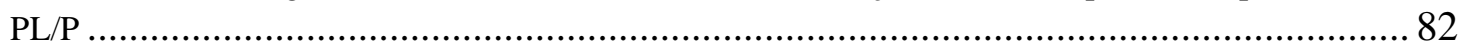

5.5 Utilidade da estratégia de investimentos baseada em informações contábeis para as empresas com baixo

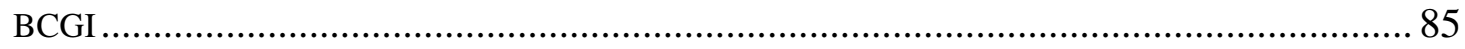

5.6 Potencializando a estratégia de investimentos baseada em informações contábeis .......................... 88

5.7 Limitações da estratégia de investimentos baseada em informações contábeis .............................. 90

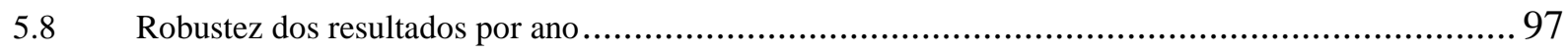

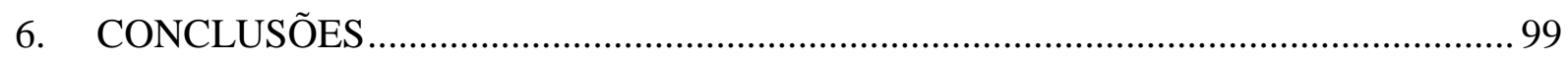

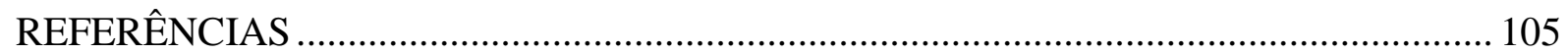

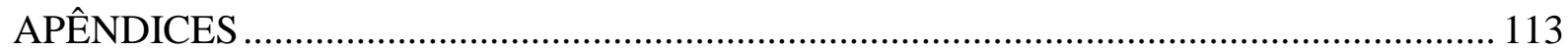




\section{LISTA DE TABELAS}

Tabela 1. Accruals das principais empresas componentes do IBOVESPA ............................ 27

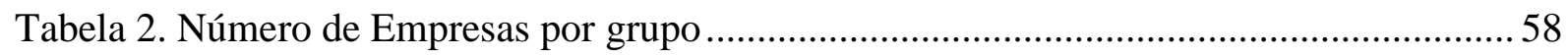

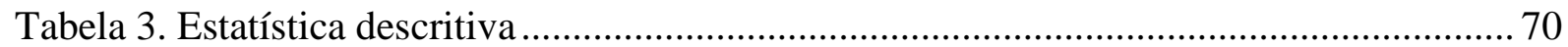

Tabela 4. Correlação de Spearman entre os componentes do BrF_SCORE e os retornos de um ano e dois anos à frente ajustados pelo mercado........................................................... 73

Tabela 5. Análise da associação do BrF_SCORE com os retornos de um ano e dois anos à

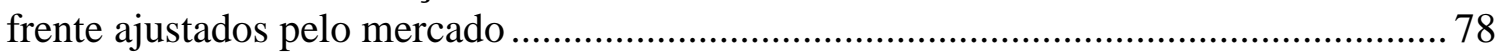

Tabela 6. Retornos da Estratégia baseada na análise de demonstrações contábeis para todas as

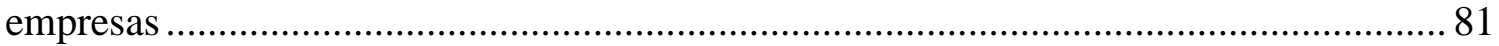

Tabela 7. Retornos da Estratégia baseada na análise de demonstrações contábeis para

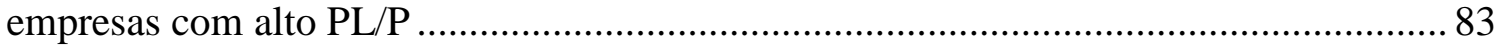

Tabela 8. Retornos da Estratégia baseada na análise de demonstrações contábeis para

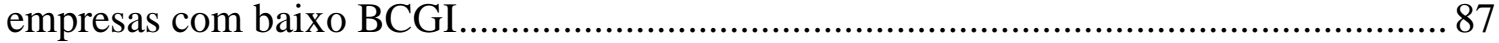

Tabela 9. Retornos da Estratégia baseada na análise de demonstrações contábeis.................. 89

Tabela 10. Contribuição dos fatores de risco para a classificação da empresa como alto PL/P

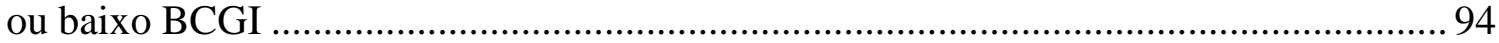

Tabela 11. Volume-ano (em $\mathrm{R} \$$ mil) negociado em Bolsa por carteira de BrF_SCORE e por

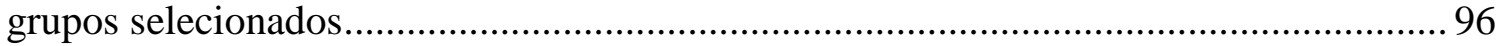

Tabela 12. Diferenças de Volume (em R \$ mil/ano) por grupo ............................................. 97 


\section{LISTA DE FIGURAS}

Figura 1. Mecanismos de governança e contabilidade para proteção do principal ................... 30

Figura 2. Crises macroeconômicas e a volatilidade mensal do IBOVESPA …....................... 43

Figura 3. Características de risco por quintil do PL/P........................................................... 93

Figura 4. Características de risco por quintil do BCGI ............................................................ 93

Figura 5. Empresas onde a estratégia apresenta melhores resultados ................................. 101 


\section{INTRODUÇÃO}

Pode-se dividir o processo de avaliação de empresas (valuation) em quatro etapas, chamadas de (i) avaliação estratégica, (ii) avaliação contábil, (iii) avaliação financeira e (iv) avaliação prospectiva (PENMAN, 2007 e PALEPU et al, 2004). A primeira etapa diz respeito à análise dos concorrentes e do entendimento do posicionamento estratégico e das vantagens competitivas da empresa no mercado em que atua. Em seguida, a avaliação contábil busca identificar a qualidade/confiabilidade das informações contidas nas demonstrações contábeis por intermédio da avaliação das políticas e das estimativas contábeis da empresa. A análise financeira, também chamada de análise de demonstrações contábeis ou análise de balanços, visa sumarizar o desempenho histórico da empresa por meio de índices e/ou indicadores. Finalmente, a análise prospectiva utiliza as informações geradas nas etapas anteriores para a projeção do desempenho da empresa. Palepu et al (2004) definem valuation como o processo de se converter uma projeção em uma estimativa do valor de uma empresa ou de alguma parte da empresa. A análise e utilização direta de informações contábeis (formada pelas etapas ii, iii e iv) são componentes essenciais no contexto de avaliação de empresas. Martins (2001, p.265) relata que a avaliação de uma empresa normalmente se inicia pelas demonstrações contábeis.

Considerando a relevância e extensa utilização da análise de demonstrações contábeis no processo de avaliação de empresas, o presente trabalho investiga a utilidade e as limitações das decisões de investimento em ações baseadas na análise de demonstrações contábeis. Alguns trabalhos abordaram o tema, principalmente para o mercado norte americano, onde as empresas estão imersas em um regime contábil de alta qualidade e, conforme demonstrado por Ball et al (2001), onde as demonstrações contábeis são informativas e mantêm uma forte relação com o preço e com o retorno das ações (ABARBANELL e BUSHEE, 1997; LEV e THIAGARAJAN, 1993; FAMA e FRENCH 1992; 1993; 1996; LAKONISHOK et al, 1994; ROSENBERG et al, 1984; DOUKAS et al, 2002; PIOTROSKI, 2000; MOHANRAN, 2005). Contudo, três inovações à literatura são apresentadas neste estudo.

A primeira delas diz respeito à investigação da utilidade de uma estratégia de investimentos baseada em informações contábeis em um país emergente e com características institucionais específicas como o Brasil. Na sequiência, o trabalho complementa o tratamento padrão da literatura ao considerar o índice brasileiro de governança corporativa (BCGI), recentemente desenvolvido por Lopes e Walker (2008), como informação adicional para a investigação da 
utilidade da análise de demonstrações contábeis. Finalmente, demonstra-se que a utilidade da análise de balanços para decisões de investimento em ações é mais eficiente para empresas/ações com características específicas e exploram-se os novos caminhos e as limitações para a implementação das estratégias.

Podem-se listar argumentos favoráveis e desfavoráveis à utilidade da análise de balanços em países com baixa qualidade de regimes contábeis (mercados emergentes). No lado positivo, Harvey (1995) mostra que o grau de previsibilidade encontrado em mercados emergentes é maior do que nos mercados desenvolvidos, o que deveria contribuir para a utilidade da análise fundamentalista - a informação contábil deveria ser mais relevante porque o mercado incorporaria as informações ao preço de maneira mais lenta. Existem evidências de que a eficiência no mercado brasileiro é menor do que no mercado norte-americano (HAQUE et al, 2001; RATNER e LEAL 1999; COSTA, 1994; KAREMERA et al., 1999; OJAH e KAREMERA, 1999). No lado negativo, pode-se argumentar que mercados emergentes são normalmente considerados como tendo um regime contábil (reporting model) pobre (ALI e HWANG, 2000). Conjectura-se que no Brasil, durante o período analisado, as características do ambiente contábil como a regulação pelo governo, a forte influência das regras fiscais nas demonstrações contábeis, o baixo nível de enforcement e os baixos montantes gastos com auditoria, contribuem para a redução da utilidade dos números contábeis. Lopes e Walker (2008) encontram evidências de que os números contábeis no Brasil são, em média, de baixa relevância (value relevance) e têm baixa tempestividade (timeliness). Ainda no lado negativo da utilidade de análise de demonstrações contábeis no Brasil, pode-se citar a grande exposição de economias emergentes às crises macroeconômicas (ORTIZ, 2002). A análise de demonstrações contábeis é desenhada de maneira a identificar riscos específicos das empresas e não de mercados e/ou economias. Em um cenário de sucessivas crises macroeconômicas como as que o Brasil tem passado recentemente (crise do México, crise da Rússia, crise da Tailândia, desvalorização do Real e efeito das eleições em 2002), a utilidade de estratégias de investimento baseadas na análise de balanços deveria ser impactada negativamente, considerando a relevância do risco sistêmico no retorno esperado. Nesse contexto a investigação da utilidade de demonstrações contábeis em um país como o Brasil torna-se importante por incorporar novos fatores aos normalmente avaliados na literatura.

A literatura tradicional (PIOTROSKI, 2000; MOHANRAN, 2005) seleciona os grupos de empresas para a aplicação da análise de balanços com base no índice patrimônio-preço (PL/P). 
Essa escolha é justificada pelas evidências de que os índices PL/P estão associados ao risco da empresa (FAMA e FRENCH, 1993, 1995 e 1996). Eid (1999, p.5) comenta:

...empresas com alto PL/P devem ser empresas ineficientes e desorganizadas. São as empresas de valor (value stocks). Será que elas permanecerão assim para sempre? Ou será que os acionistas vão clamar por mudanças, reorganização e reestruturação de forma tal que os ganhos destas empresas retornem aos níveis médios de mercado? Se isto ocorrer, os retornos serão surpreendentemente bons.

Análises empíricas demonstram que carteiras de ações formadas por empresas com alto PL/P apresentam retornos acima dos obtidos pela carteira de mercado ${ }^{1}$. Piotroski (2000) argumenta que a análise de indicadores financeiros deveria ser mais efetiva nas empresas com alto PL/P (empresas estressadas financeiramente) do que no conjunto geral de empresas. O presente trabalho inova ao considerar, adicionalmente às partições realizadas com base no PL/P, a seleção de empresas com base em seus níveis de governança corporativa (BCGI). Esta classificação é independente de métricas de mercado e de métricas contábeis, e possibilita a comparação com os resultados obtidos com em estratégias focadas na seleção de empresas com base no PL/P. Assim, espera-se obter um melhor entendimento da utilidade da análise de demonstrações contábeis ao se considerar seus efeitos nos dois grupos mencionados.

A literatura aponta para uma forte relação entre a contabilidade financeira e os mecanismos de governança corporativa ${ }^{2}$. Bushman e Smith (2001, p.238) relatam ${ }^{3}$ que:

Os sistemas da contabilidade financeira fornecem inputs diretos para os mecanismos de controle corporativo, bem como fornecem inputs indiretos ao contribuir para a informação contida nos preços das ações. Um objetivo fundamental da pesquisa de governança em contabilidade é encontrar evidências sobre o quanto as informações fornecidas pelos sistemas de contabilidade financeira mitigam os problemas de agência decorrentes da separação entre administradores e investidores externos, facilitando o fluxo eficiente dos escassos capital humano e financeiro para gerar oportunidades de investimento. Nós acreditamos que a pesquisa em governança é importante por desenvolver um entendimento completo do impacto da informação contábil na alocação e utilização de recursos na economia.

Complementarmente, Bushman et al (2004, p.193) argumentam que apesar dos sistemas de informação contábil poderem influenciar diretamente as escolhas de governança, também deve-se

\footnotetext{
${ }^{1}$ Este fenômeno é chamado de high book-to-market effect (HBM effect).

${ }^{2}$ Bushman e Smith (2001) e Sloan (2001) fazem uma extensa revisão sobre o assunto.

${ }^{3}$ Tradução Livre de: "Financial accounting systems provide direct input to corporate control mechanisms, as well as providing indirect input to corporate control mechanisms by contributing to the information contained in stock prices. A fundamental objective of governance research in accounting is to provide evidence on the extent to which information provided by financial accounting systems mitigate agency problems due to the separation of managers and outside investors, facilitating the efficient flow of scarce human and financial capital to promising investment
} 
considerar a possibilidade das estruturas de governança influenciarem as propriedades dos números contábeis através de escolhas de políticas contábeis e de atividades de gerenciamento de resultado. Dechow et al (1996), por exemplo, encontraram evidências de que empresas com violações nos GAAPs tinham maior probabilidade de ter seus Conselhos ${ }^{4}$ dominados por membros internos. Girox (2006, p.41) relata que na perspectiva do investidor, a estrutura de governança sinaliza a credibilidade esperada no sistema de geração das demonstrações contábeis e um sistema de governança fraco é mais facilmente dominado pelo $\mathrm{CEO}^{5}$, o que pode resultar em uma menor qualidade do lucro. Segundo Dechow e Schrand (2004) a qualidade do lucro se relaciona com três características desejáveis: i) ele deve refletir a performance atual da empresa, ii) deve ser útil para a projeção da performance futura e iii) deve ser convertido por modelos de forma a representar o valor intrínseco da empresa de forma acurada. Espera-se, portanto, que empresas com melhor governança apresentem lucros contábeis de maior qualidade. Contudo, o impacto dos níveis de governança corporativa na relevância da análise de informações contábeis para seleção de carteiras de ações é complexo. Isto porque pode haver efeitos da governança diretamente nos preços, efeitos da governança diretamente na qualidade das informações contábeis e efeitos da governança diretamente na assimetria informacional da empresa com o mercado.

Os resultados obtidos em estudos que avaliam a relação entre governança e retorno das ações são controversos. Em um trabalho seminal Gompers et al (2003) demonstraram que uma carteira comprada em ações com alta governança e vendida em ações com baixa governança obteve um retorno anormal de 8,5\% ao ano de 1990 a 1999. Usando proxies ${ }^{6}$ de mecanismos de governança interna e externa, Cremers e Nair (2005) também encontram um resultado positivo para uma carteira formada por empresas mais vulneráveis a aquisições hostis em relação às menos vulneráveis. Entretanto, Core et al (2006) encontram evidências de que diferenças nos sistemas de governança corporativa não causam maiores retornos. Core et al (2006) replicaram a carteira de Gompers et al (2003) para um período estendido e realizaram testes adicionais para chegar a esta conclusão. Outros trabalhos (BROWN e CAYLOR, 2006) estabelecem uma relação entre governança e preço (mais especificamente Q de Tobin) ou custo de capital (ANDERSON et al,

opportunities. We believe that governance research is important for developing a complete understanding of the impact of financial accounting information on the allocation and utilization of resources in an economy".

${ }^{4}$ Exemplos de órgãos de decisão nas companhias abertas são: Conselho de Administração, Comitê de Remuneração, Conselho Fiscal, Comitê de Auditoria, entre outros.

${ }^{5}$ Chief executive officer, correspondente ao presidente executivo ou diretor-presidente da empresa.

${ }^{6}$ Variáveis representativas das características em análise; aproximações. 
2004). Algumas das críticas ao trabalho de Gompers et al (2003) e posteriores que utilizaram o G-Index (índice de governança corporativa desenvolvido pelo Investor Responsibility Research Center - IRRC) residem no fato que o índice é focado na proteção de aquisições hostis e não contempla outros fatores inerentes ao conceito de governança corporativa. Neste contexto o presente trabalho insere-se na discussão ao utilizar um recém desenvolvido índice de governança (LOPES e WALKER, 2008) e que congrega 4 dimensões (disclosure, estrutura acionária, composição do conselho e direitos dos acionistas) para investigar a relevância da análise de demonstrações contábeis para empresas com diferentes níveis de governança.

Adicionalmente, o presente trabalho apresenta um modelo simples relacionando o preço das ações e o nível de governança da empresa. Ao desenvolver o modelo cria-se uma base teórica para se conjecturar que aumentos no nível de governança exercem impactos positivos nos preços das ações. Entretanto, conforme evidenciado por Kanagaretnan et al (2007), empresas com maior nível de governança corporativa reduzem a assimetria informacional, aumentando a eficiência do mercado com relação ao preço das ações da empresa. Portanto, espera-se que quanto maior a governança da empresa, maior será seu preço e mais rapidamente a informação nele será refletida, diminuindo, assim, a eficácia da análise de demonstrações contábeis para a identificação de oportunidades de investimento que gerem retornos anormais. Por outro lado, espera-se que o mercado atue mais lentamente para refletir as informações publicadas por empresas com arranjos fracos de governança corporativa. Este trabalho contribui para a literatura ao analisar empiricamente esta questão.

Consistentemente com a literatura internacional (PIOTROSKI, 2000), considera-se que os sinais obtidos com a análise de demonstrações contábeis para decisões de investimento em ações tendem a ser mais inteligíveis para empresas em más condições financeiras. Piotroski (2000) também sugere que as demonstrações contábeis representam a fonte mais acessível e crível para este tipo de empresa. De fato, empresas com saúde financeira mais fraca têm menor acesso aos diversos mecanismos de disseminação de informações no mercado de capitais (bem como empresas com menor nível de governança corporativa), o que torna as demonstrações contábeis uma fonte única de informações para investidores em ações. Pode-se argumentar que a análise de indicadores financeiros fica mais clara para empresas com pouca saúde financeira. Por exemplo, o aumento da alvancagem per si não é necessariamente uma má informação. Contudo, quando este aumento acontece para empresas altamente endividadas, este provavelmente é um mau sinal. 
Nestas situações, os sinais financeiros tornam-se informações bastante relevantes sobre a perspectiva futura das empresas.

As evidências mostram que altos índices patrimônio-preço (PL/P) são positivamente correlacionados com os indicadores de empresas em situação financeira difícil. Assim utiliza-se este índice para se selecionar empresas em más condições financeiras. Também se deve considerar que o índice PL/P é uma proxy do risco da ação (FAMA e FRENCH, 1992, 1993 e 1996).

Nessas condições, pode-se conjecturar que a utilidade da análise de demonstrações contábeis deve ser maior para empresas com alto índice PL/P e/ou com arranjos de governança corporativa mais fracos. Isso porque empresas nestes grupos classificadas como fortes financeiramente têm boas perspectivas futuras e comunicam mal suas informações para o mercado (pouco acesso ao mercado e/ou má governança corporativa). Essas características podem fazer com que o preço deste tipo de ação demore mais a refletir os fundamentos da empresa, propiciando um ganho maior para o investidor que as identificar.

Outro ponto relevante é a necessidade da existência de empresas subavaliadas ou superavaliadas como condição para que estratégias de investimento baseadas em informações divulgadas para o mercado tenham efeito. Assim, ao se analisar este tipo de estratégia, avalia-se também o nível de eficiência do mercado de capitais. Em mercados mais eficientes, espera-se que estas estratégias tenham um menor desempenho do que em mercados menos eficientes.

Guay (2000) argumenta que o sucesso de estratégias baseadas na análise de informações contábeis pode ser explicado por: (i) ineficiência do mercado, (ii) por modelos comportamentais de reações exageradas ou atenuadas, (iii) por fatores de risco omitidos e (iv) porque os resultados obtidos não podem ser alcançados em mercados reais devido aos limites de negociação existentes. Este trabalho explora estes aspectos ao buscar uma explicação condizente com o paradigma da teoria de finanças para os resultados obtidos com a aplicação das estratégias.

Esta pesquisa contribui com os órgãos normatizadores da contabilidade para o melhor entendimento da relação entre a utilidade da análise de demonstrações contábeis e características 
específicas das empresas. Tanto o $\mathrm{IASB}^{7}$, o $\mathrm{FASB}^{8}$, a $\mathrm{SEC}^{9}$, a $\mathrm{CVM}^{10}$ e o $\mathrm{CPC}^{11}$ deixam claro que um dos objetivos da informação contábil é ser útil no processo de avaliação/tomada de decisões por agentes externos à empresa. O FASB (1978, p.16-22) relata em seu Statement of Financial Accounting Standards Concepts No. 1 que os objetivos das demonstrações contábeis são o de prover informações: i) úteis para a tomada de decisão de investimento e de crédito, ii) úteis para a avaliação de fluxos de caixa futuros, iii) sobre recursos econômicos da empresa, suas obrigações e o patrimônio de seus acionistas, iv) sobre a performance e o lucro da entidade, v) sobre a liquidez, solvência e o fluxo de recursos, vi) para a avaliação da performance dos administradores da entidade e vii) que contenham explicações e interpretações dos administradores com o intuito de elucidar o entendimento das informações financeiras. O IASB (2007) tem uma posição bastante parecida com a do FASB.

No Brasil a estrutura fundamental da contabilidade emitida pelo Ipecafi ${ }^{12}$, aprovada e divulgada pelo Ibracon $^{13}$ e referendada pela CVM relata que o objetivo principal da contabilidade é o de permitir, a cada grupo principal de usuários, a avaliação da situação econômica e financeira da entidade, num sentido estático, bem como fazer inferências sobre suas tendências futuras (IUDÍCIBUS et al, p.30). Mais recentemente o CPC apresentou o arcabouço conceitual básico da contabilidade onde os objetivos são bastante convergentes com os apresentados pelo IASB e pelo FASB. Assim, o melhor entendimento da utilidade da análise de demonstrações contábeis traz contribuições aos agentes reguladores, considerando-se os objetivos da contabilidade.

Adicionalmente, o tema em estudo é de interesse para a prática de análise fundamentalista e avaliação de empresas no sentido de como devem ser entendidos os números contábeis vis-à-vis algumas características da empresa e da ação que está sendo avaliada. O gestor de um fundo de investimentos gostaria de saber se a análise de demonstrações contábeis funciona igualmente para todas as empresas. Gestores de fundos ativos, ou seja, aqueles que buscam ganhos superiores aos proporcionados pelos índices de mercado, podem se beneficiar com os resultados (incluindo as limitações da estratégia) obtidos neste estudo.

\footnotetext{
${ }^{7}$ International Accounting Standards Board.

${ }^{8}$ Financial Accounting Standards Board.

${ }^{9}$ Security and Exchange Commission.

${ }^{10}$ Comissão de Valores Mobiliários.

${ }^{11}$ Comitê de Pronunciamentos Contábeis.

${ }^{12}$ Instituto Brasileiro de Pesquisas Contábeis, Atuariais e Financeiras.

${ }^{13}$ Instituto dos Auditores Independentes do Brasil.
} 


\subsection{Problema de Pesquisa e Hipóteses}

Com o objetivo geral de se avaliar cientificamente a utilidade da análise de demonstrações contábeis para a seleção de investimentos em ações, este trabalho investiga o seguinte problema:

\section{É possível obter retornos anormais com aplicações em ações utilizando-se a análise de demonstrações contábeis para a identificação de boas oportunidades de investimento no mercado de capitais brasileiro?}

Com base no problema apresentado, levantam-se as hipótese para a avaliação da utilidade da análise de balanços para a seleção de uma carteira de investimentos:

H1 - A seleção de uma carteira de ações composta por empresas fortes financeiramente dentro do grupo das empresas negociadas na Bovespa gera retornos acima dos obtidos pelo índice de mercado (retornos anormais).

Esta primeira hipótese é condizente com a idéia de que um investidor pode desenhar sua estratégia de aplicação somente com base em indicadores financeiros extraídos das demonstrações contábeis publicadas pelas empresas.

Trabalhos clássicos sobre estratégias de investimento baseadas em análise de demonstrações contábeis (PIOTROSKI, 2000; MOHANRAN, 2005) aplicam a avaliação dos indicadores financeiros para um grupo específico de empresas. Piotroski (2000) utilizou os sinais financeiros tradicionalmente abordados na análise de balanços para selecionar as empresas fortes financeiramente dentro do grupo de empresas com alto índice PL/P. Mohanran (2005) selecionou as empresas com baixo PL/P e desenvolveu um índice baseado em informações financeiras que diferenciasse ações com boa e má performance futura. Este trabalho expande esta análise ao considerar o conjunto completo de empresas, as empresas com alto PL/P, uma partição adicional que considera a governança corporativa da empresa e uma que representa a interseção entre as empresas com alto PL/P e baixo BCGI.

É importante ressaltar que o índice PL/P é impactado pela avaliação da empresa pelo mercado e, também, por práticas contábeis da empresa. O índice PL/P pode ser alto, pois o patrimônio 
líquido está superavaliado, ou porque o preço está subavaliado, ou uma combinação de ambos. O efeito resultante de se selecionar ações com alto PL/P para a composição de uma carteira, chamado de efeito de ações com alto índice PL/P, é bastante difundido na literatura (FAMA e FRENCH, 1993, 1996). Este tipo de formação de carteira resulta em aumento do retorno em relação ao retorno de mercado. As explicações para este fenômeno são diversas, mas grande parte delas associa o incremento no retorno pelo aumento do risco da carteira. Nesse contexto o índice PL/P seria uma proxy para o risco idiossincrático da empresa. Contudo, este índice é impactado por informações de mercado e por informações contábeis. Assim, ele sofre influência das turbulências do mercado e de escolhas de políticas contábeis da empresa. Piotroski (2000) explorou mais detalhadamente este fenômeno e demonstrou que a análise de demonstrações contábeis contribui para um aumento ainda maior nos retornos obtidos ao se selecionar empresas com alto PL/P e com bons sinais financeiros. O presente trabalho utiliza uma partição adicional independente da volatilidade do mercado e de políticas contábeis. Esta partição é baseada no índice brasileiro de governança corporativa (BCGI) desenvolvido de maneira a capturar 4 dimensões da governança corporativa. O BCGI ${ }^{14}$ (Lopes e Walker, 2008) foi construído com base em quinze itens que são extraídos de fontes públicas de informação (por exemplo, o website de relações com investidores da empresa) e mensura os atributos de (i) disclosure, (ii) composição do conselho e funcionamento, (iii) estrutura acionária e controle e, (iv) direitos dos acionistas.

Com a utilização do BCGI, é possível avaliar o funcionamento das estratégias de investimento baseadas em informações contábeis para dois grupos distintos ${ }^{15}$ sem ter como impacto direto, para a seleção de um deles, os preços de mercado e/ou de escolhas contábeis. Como o BCGI não depende diretamente de informações de mercado e a maioria de seus componentes somente são modificados com decisões estratégicas das empresas (por exemplo a atuação independente do conselho de adminstração ou o aumento do free float), pode-se dizer que seu comportamento é menos volátil do que o do índice PL/P, o que pode resultar em ganhos adicionais nas análises a serem realizadas.

Com a possibilidade de se avaliar a utilidade de análise de demonstrações contábeis em dois grupos de empresas distintos e pouco correlacionados, onde presumivelmente a análise de

\footnotetext{
${ }^{14}$ Veja Apêndice A para detalhes.

${ }^{15}$ Veja seção 4.2 .
} 
demonstrações contábeis tende a ser mais efetiva, podem-se levantar as seguintes hipóteses de pesquisa:

H2 - A seleção de uma carteira de ações composta por empresas fortes financeiramente dentro do grupo das empresas com alto índice PL/P gera retornos anormais.

H3 - A seleção de uma carteira de ações composta por empresas fortes financeiramente dentro do grupo das empresas com baixo BCGI resulta em retornos anormais.

Pode-se conjecturar duas hipóteses adicionais com relação ao grupo de empresas que pertencem aos dois grupos (alto PL/P e baixo BCGI) onde a utilização de informações contábeis para a elaboração de estratégias de investimento tende a ser mais relevante:

H4 - A utilidade da análise de demonstrações contábeis para seleção de carteiras de investimento é maior para empresas em situação de estresse financeiro (representado pelo alto índice PL/P) e com arranjos de governança corporativa mais fracos (baixo BCGI).

H5 - As características de risco das empresas fortes financeiramente no grupo das empresas com alto índice PL/P e no grupo das de baixo BCGI são semelhantes e explicam o resultado obtido na estratégia de investimentos baseada na análise de demonstrações contábeis.

\subsection{Metodologia}

Com o objeto de investigar as hipóteses levantadas sobre a utilidade da análise de balanços, este trabalho adota a metodologia positiva de pesquisa em contabilidade (IUDÍCIBUS e LOPES, 2004). Esta metodologia, mais especificamente caracterizada de capital markets research in accounting, no subitem capital markets research on fundamental analysis (KOTHARI, 2001), parte de uma motivação teórica eminentemente econômica gerando hipóteses que são empiricamente testadas. Ainda segundo Kothari (2001, p.109) a pesquisa nesta área visa avaliar se a análise fundamentalista é capaz de identificar com sucesso ações que estejam mal precificadas.

Este trabalho se caracteriza como empírico-analítico, que, segundo Martins (2000, p. 26), é uma abordagem que utiliza técnicas de coleta, tratamento e análise de dados. Dada as hipóteses de 
pesquisa, há uma forte preocupação com a relação causal entre variáveis. A investigação é realizada através de análises estatísticas e econométricas amplamente utilizadas nas pesquisas em contabilidade.

\subsection{Limitações}

Todo trabalho de natureza empírico-analítica tem como objetivo sintetizar a realidade por meio de modelos simplificadores. Este trabalho não é exceção e ao utilizar o ferramental estatístico/econométrico busca obter evidências para servirem de base para refutação ou não das hipóteses levantadas. Contudo estes modelos não são capazes de capturar toda a complexidade subjacente à economia. Abaixo são apresentadas as principais limitações do trabalho juntamente com comentários sobre o impacto das mesmas na interpretação dos resultados encontrados:

i. Custos de transação: como o trabalho aborda a formação de carteiras para investimento, há custos de transação (por exemplo, corretagens, emolumentos, taxa de custódia e impostos). Estes não foram considerados por serem idiossincráticos de cada investidor e por se acreditar que o impacto nos retornos obtidos não alteraria as conclusões deste trabalho;

ii. Amostra de empresas brasileiras: considerando-se que os dados representam as companhias abertas brasileiras listadas em Bolsa de Valores, as conclusões obtidas ficam, de certa forma, restritas à amostra utilizada;

iii. Período avaliado: apesar do período avaliado ser relativamente longo (oito anos), sabe-se que o mercado de capitais brasileiro vem passando por significativas alterações institucionais. Este fato deve ser lembrado na interpretação dos resultados.

iv. Utilização de um índice agregado (BrF_SCORE) para a análise de todas as empresas: com o objetivo de viabilizar a comparação dos resultados e congregar os principais indicadores financeiros, utiliza-se o mesmo índice agregado ${ }^{16}$ para se avaliar os sinais financeiros das diferentes empresas. 


\subsection{Estrutura do Trabalho}

O restante do trabalho está organizado conforme relatado a seguir. O capítulo 2 apresenta a fundamentação teórica abordando pesquisas que mostram evidências relacionadas à estratégias de investimento baseadas em informações contábeis, à importância do regime de competência nas demonstrações contábeis e da relação entre governança corporativa e valor da empresa. Adicionalmente, apresenta-se o ambiente institucional e a estrutura do mercado brasileiro para se entender melhor o papel da contabilidade como fonte de informação para os investidores. O capítulo 3 apresenta o modelo desenvolvido neste trabalho com o intuito de demonstrar a relação teórica entre governança e preço. O capítulo 4 detalha o desenho de pesquisa para avaliar as hipóteses relacionadas no item 1.1. O capítulo 5 apresenta os testes empregados e os resultados obtidos na análise empírica. Finalmente, o capítulo 6 conclui e sugere temas para pesquisas futuras.

\footnotetext{
${ }^{16}$ Muitas vezes os analistas utilizam indicadores específicos por setor, ou até mesmo por um conjunto de empresas, de maneira a capturar melhor a sua realiadade econômica.
} 


\section{FUNDAMENTAÇÃO TEÓRICA}

O mercado de capitais em um mundo ideal não teria fricções, seria eficiente da forma forte, teria um conjunto de informações completas e perfeitas, não contemplaria custos de transação e seria composto por gestores orientados a sempre maximizar a riqueza dos acionistas. Neste ambiente não haveria espaço para mecanismos que buscam diminuir as incertezas decorrentes das idiossincrasias do real funcionamento dos mercados. Entre esses mecanismos estão a geração, divulgação e análise de informações contábeis, bem como as práticas de governança corporativa.

A análise de demonstrações contábeis é a base do processo de avaliação de empresas (PALEPU et al, 2004; PENMAN 2007). A análise fundamentalista (denominação por vezes dada ao processo de análise de demonstrações contábeis) baseia-se na idéia de que investidores sofisticados têm a capacidade de utilizar informações financeiras históricas passadas de maneira a elaborar estratégias de investimento lucrativas (PIOTROSKI, 2005). Assim, considera-se que a análise criteriosa e detalhada de demonstrações contábeis pode resultar em informações relevantes para a tomada de decisões. De fato este é um dos objetivos da contabilidade de acordo com o arcabouço conceitual estabelecido pelos órgãos normatizadores. Contudo, uma hipótese central para o funcionamento de estratégias de investimento baseadas em informações contábeis se refere ao nível de eficiência do mercado de capitais. Fama $(1970,1976)$ define três formas de eficiência de mercado:

1. Forma Fraca de Eficiência: nenhum investidor consegue ganhar retornos anormais baseando-se em estratégias que utilizam como informação os preços ou retornos históricos das ações. Nesse caso os preços/retornos passados não são relevantes para obtenção de retornos anormais.

2. Forma Semi-Forte de Eficiência: os investidores não conseguem ganhar retornos anormais baseando-se em estratégias que utilizam informações publicamente disponíveis, pois estas são incorporadas rapidamente aos preços. Entre estas informações estariam as demonstrações contábeis das empresas.

3. Forma Forte de Eficiência: nenhum investidor consegue ganhar retornos anormais com base em informações (públicas e privadas), pois todas elas já estão incorporadas aos preços. Em mercados eficientes da forma forte, estratégias de investimento baseadas em informações contábeis não deveriam surtir efeito. 
Pode-se conjecturar que a utilização de análise de balanços apresentará maior utilidade para a seleção de carteiras de investimento em ações se o mercado não capturar de maneira eficiente e rápida todas as informações disponíveis. Assim, pode-se argumentar que o objetivo do uso dos modelos de análise e avaliação de empresas, dos quais a análise de balanços é um subconjunto, está diretamente relacionado ao nível de eficiência do mercado de capitais. Kothari (2001, p.109) comenta $^{17}$ :

\begin{abstract}
A crença de que o "processo de convergência do preço ao valor é um processo mais demorado do que as evidências anteriores demonstravam" (Frankel and Lee, 1998, p.315) tem adquirido cada vez mais aceitação entre os principais acadêmicos, incentivando a pesquisa em análise fundamentalista. A pesquisa de mercado de capitais em análise fundamentalista avalia se esta identifica com sucesso títulos mal precificados. A pesquisa em análise fundamentalista, portanto, não pode ser dissociada da pesquisa sobre eficiência do mercado.
\end{abstract}

Diversos autores investigaram a hipótese do mercado eficiente para o caso específico do Brasil. Contador (1973), Brito (1978) e Muniz (1980) foram os pioneiros nessa análise. De forma geral, esses trabalhos iniciais, realizados com dados de ações negociadas na Bolsa do Rio de Janeiro, apontavam que o mercado de capitais brasileiro era, no mínimo, eficiente da forma fraca. Ou seja, não seria possível obter retornos anormais com base apenas em informações históricas dos preços. Trabalhos posteriores (SCHIEHLL, 1996; PEROBELLI e NESS, 2000; PROCIANOY e ANTUNES, 2001; KAREMERA et al, 1999; OJAH e KAREMERA, 1999; HAQUE et al, 2001; RATNER e LEAL, 1999; Da COSTA, 1994) estenderam e aprimoraram as análises e de forma geral concluem que o mercado de capitais brasileiro não é eficiente da forma forte.

No que tange a eficiência informacional relacionada às informações contábeis, a literatura internacional sugere a não eficiência do mercado de capitais com relação aos números contábeis e aponta para a relação destes com os retornos das ações, bem como para a utilidade de estratégias de investimento baseadas em análise de balanço (OU e PENMAN, 1989a,b; LEV e THIAGARAJAN, 1993; ABARBANELL e BUSHEE, 1998; PIOTROSKI, 2000; MOHANRAN, 2005). Adicionalmente, ao se considerar a prática no mercado de capitais (milhares de analistas trabalhando no sentido de encontrar empresas que estejam subvalorizadas ou supervalorizadas), pode-se dizer que há evidências da relevância da análise de demonstrações contábeis para a alocação de recursos. Este é o resultado esperado considerando-se o volume de recursos

\footnotetext{
${ }^{17}$ Tradução Livre de: "The belief that 'price convergence to value is a much slower process than prior evidence suggests' (Frankel and Lee, 1998, p.315) has acquired currency among leading academics, spurring research on fundamental analysis. Capital markets research on fundamental analysis examines whether it successfully identifies mispriced securities. Fundamental analysis research thus cannot be disentangled from capital markets research on testing market efficiency".
} 
investidos nesta atividade. Exemplos incluem as avaliações feitas por analistas do mercado de capitais, por investidores institucionais, por bancos de investimento e até mesmo a análise realizada por investidores individuais. Contudo, essas evidências estão concentradas no mercado norte-americano, onde algumas características são bastante distintas das encontradas no mercado brasileiro. Esses fatores, em conjunto com as evidências da hipótese do mercado eficiente para o mercado brasileiro, tornam importante a investigação da eficácia de uma estratégia de investimento baseada em informações contábeis.

Outra importante constatação relacionada com o tema em estudo é a existência de fundos de investimento ativos e passivos. Os primeiros são aqueles que buscam ganhos superiores aos proporcionados pelos índices de mercado. Para isso, formam carteiras de ativos diferentes da carteira de mercado. Já, os últimos, são fundos que buscam proporcionar ganhos alinhados com algum índice de mercado. Em um recente estudo, Rochman e Eid (2006) investigam fundos ativos e passivos atuantes no mercado brasileiro e encontram evidências de que a gestão ativa agrega valor para o investidor no caso de fundos de ações e multimercados. Segundo os autores os investidores deveriam procurar fundos ativos, com maiores patrimônios líquidos e mais antigos. Nesse contexto, pode-se depreender que alguns gestores de fundos de investimento ativos no Brasil possuem estratégias que, de acordo com as evidências apresentadas por Rochman e Eid (2006), podem suplantar os retornos obtidos com a carteira mercado. Esse fato corrobora para a investigação empírica da eficácia de estratégias de investimento baseadas na análise de demonstrações contábeis para o mercado brasileiro. Seriam essas estratégias passíveis de serem utilizadas por gestores de fundos ativos?

\subsection{Informações contábeis, governança e modelos de avaliação de empresas}

Dentro do conceito de avaliação de empresas (valuation), a análise fundamentalista (análise de demonstrações contábeis) é um componente central para a tomada de decisões (PALEPU et al, 2004; PENMAN 2007). Martins (2001, p.268) classifica os métodos de avaliação de empresas em: técnicas comparativas de mercado, técnicas baseadas em ativos e passivos contábeis ajustados e técnicas baseadas no desconto de fluxo futuros de benefícios. Entre os modelos de valuation mais difundidos destacam-se os métodos de desconto do fluxo de dividendos, os modelos de fluxos de caixa descontados e os modelos de avaliação por múltiplos de mercado. Livros-texto tradicionais de finanças (DAMODARAN, 2002; BREALEY e MYERS, 2000; BRIGHAM et al, 2001; COPELAND et al, 2000) concentram-se na disseminação do conceito de 
fluxo de caixa descontado como sendo o recomendado para a avaliação de empresas. No Brasil essa metodologia é considerada, inclusive, para disputas jurídicas nos casos onde há a necessidade de determinação do valor das ações de uma companhia. Nos casos de cancelamento de registro de companhia aberta, nas ofertas públicas de ações (OPA) por alienação de controle, nas OPAs por cancelamento de registro e nas OPAs por aumento de participação, além de casos onde exista direito de recesso dos acionistas dissidentes, a legislação aceita o uso da metodologia do fluxo de caixa descontado, além das tradicionais técnicas baseadas em ativos e passivos contábeis ajustados. Contudo vale salientar, conforme constatado por Paulo et al (2006), que em casos de dissoluções societárias em função da retirada ou falecimento de um ou mais sócios, os procedimentos de avaliação tendem a ser mais conservadores e baseados em ajustes dos saldos contábeis.

Adicionalmente, pode-se dizer que a relevância da utilização de informações contábeis nos modelos de avaliação de empresas, notadamente o lucro e o patrimônio líquido, sofreu uma significativa alteração a partir da segunda metade da década de 90 do século XX. Tanto a literatura acadêmica contábil $^{18}$ quanto à prática dos analistas de mercado de capitais ${ }^{19}$ foi influenciada significativamente pelos modelos apresentados por Ohlson $(1995,2005)$ e Ohlson e Juettner-Nauroth (2005). Estes modelos formalizam a relação entre as informações contábeis e o preço de uma ação. Neste contexto, a utilização da análise de demonstrações contábeis como base para a seleção de investimentos em ações, que já era difundida na prática dos analistas de mercado de capitais, passa a ser um tema com embasamento teórico consistente para a realização de pesquisas. Este trabalho foca sua atenção no processo de análise financeira, considerando uma estratégia de investimento baseada nos fundamentos apresentados nas demonstrações contábeis da empresa. No processo de análise de balanços busca-se avaliar a saúde financeira de uma empresa com base nos seus indicadores. Espera-se que a alocação de recursos em empresas com bons indicadores e que ainda não estão refletidos nos preços de mercado resulte em retornos acima dos da média de mercado.

\footnotetext{
${ }^{18}$ Exemplos incluem: Bernstein e Wild (1997), Palepu et. al. (2004), Penman (2007), Revsine et.al. (2000), Soffer and Soffer (2003), White et.al. (2003), Beaver (1998), Christensen and Feltham (2003), Christensen and Demski (2003), Lopes (2001), Iudícibus e Lopes (2004) e Lopes e Martins (2005).

${ }^{19}$ Demirakos, Strong e Walker (2004) investigam a utilização dos modelos de avaliação pelos analistas e relatam que, aparentemente, os analistas adaptam suas metodologias de valuation de acordo com as características do setor da empresa que estão analisando.
} 
A relação entre governança corporativa e preço das ações também tem sido extensivamente investigada pela literatura. Gompers et al (2003) montaram um índice de governança que avalia o direito dos acionistas e descobriram que uma estratégia de investimentos baseada na compra de empresas com altos índices de governança e na venda de empresas com baixos índices de governança, resultaria em um retorno anormal de 8,5\% ao ano para o período analisado. Aparentemente empresas com melhores índices de governança têm maiores lucros, maiores crescimento das vendas e maior valor de mercado. Alternativamente, Core et al (2006) expandiram o estudo de Gompers et al (2003) e demonstraram não haver relação entre altos retornos e sistemas mais fortes de governança. Nesse sentido a relação entre governança e retorno das ações ainda é um tema a ser explorado. O presente trabalho investiga indiretamente esta questão ao avaliar se uma estratégia de investimento baseada na análise de demonstrações contábeis funciona igualmente para empresas com diferentes arranjos de governança corporativa.

Os próximos tópicos apresentam com maiores detalhes a revisão da literatura dos temas relacionados com a utilidade da análise de demonstrações contábeis para elaboração de estratégias de investimento e com a ligação entre governança coporativa e o valor/retorno das ações.

\subsection{Estratégias de Investimento baseadas na Análise de Demonstrações Contábeis}

Desde o clássico livro de Graham e Dodd (1934) estratégias de investimento baseadas em números contábeis, também chamadas de análise fundamentalista, têm sido difundidas como forma de proporcionar retornos superiores aos de mercado. Inicialmente essas estratégias focavam na compra de ações com baixo índice preço/valor patrimonial (P/VPA) - que é equivalente a um alto índice patrimônio líquido/preço (PL/P) - e diziam que estas produziam um retorno maior do que estratégias baseadas em comprar ações com altos índices P/VPA. Desde então existe uma extensa literatura que aborda o tema de maneira a desenvolver estratégias de investimento baseadas em números contábeis que tenham desempenho acima do mercado (ABARBANELL e BUSHEE, 1998; LEV e THIAGARAJAN, 1993; FAMA e FRENCH 1992; 1993; 1996; LAKONISHOK et al., 1994; ROSENBERG et al, 1984; DOUKAS et al, 2002). Existe um grande número de evidências, principalmente em mercados desenvolvidos, de que carteiras de ações com alto índice PL/P têm um desempenho melhor do que carteiras formadas por ações de empresas com baixo índice PL/P. Rosenberg, Reid e Lansteisn (1984), Fama and French $(1992,1993,1996)$ e Lakonishok et al (1994) concordam que o índice PL/P é fortemente 
e positivamente correlacionado com o desempenho futuro da ação. Esse resultado é conhecido na literatura como efeito de empresas com alto PL/P (high book-to-market). Contudo as explicações relativas ao referido efeito não são uniformes. Fama e French (1992, 1993 e 1996) relatam que o bom desempenho das ações com alto índice PL/P é explicado pelos altos riscos enfrentados por este tipo de empresa. Vassalou e Xing (2004) argumentam que o risco de empresas com alto PL/P é uma proxy para o risco de default. Portanto, empresas mais arriscadas devem fornecer a seus investidores um maior retorno. Por outro lado, Lakonishok et al (1994) argumentam que o efeito do bom desempenho de ações de empresas com alto PL/P é explicado por uma má atribuição de preço pelo mercado (mispricing). De acordo com estes autores, empresas com altos índices PL/P são empresas negligenciadas ${ }^{20}$ no mercado, nas quais o desempenho anterior gera expectativas pessimistas sobre a performance futura. Análises adicionais dão sustentabilidade à explicação de má atribuição de preço pelo mercado. Ali et al (2003) mostram que o efeito PL/P é maior para ações com maior volatilidade dos retornos idiossincráticos, com maiores custos de transação e que têm maior números de investidores menos sofisticados.

No caso brasileiro, Eid (1999) avaliou a existência do efeito de empresas com alto PL/P para uma amostra de ações negociadas na Bovespa para o período de 1989 a 1997. Os resultados obtidos contrariam as evidências internacionais, mas como o próprio autor comenta, algumas deficiências como problemas com os dados da época, os altos níveis de inflação e a amostra reduzida podem ter influenciado seu resultado. Posteriormente, Lima (2003) avalia a existência do efeito de empresas com alto PL/P para o mercado brasileiro para o período de junho de 1994 a dezembro de 2001 e confirma sua existência. O presente trabalho, apesar de não ter como objetivo direto a investigação da existência do efeito de empresas com alto PL/P no mercado brasileiro, realiza esta avaliação e confirma as evidências internacionais. Portanto, pode-se dizer, ao menos para o período posterior à implantação do plano-real, que existem fortes evidências da existência do efeito de empresas com alto PL/P no mercado brasileiro.

Em um trabalho recente, Penman et al (2007) decompõem o índice PL/P de maneira a demonstrar que ele pode ser representado por dois fatores. O primeiro deles diz respeito ao índice PL/P dos ativos operacionais da empresa (que reflete o risco operacional) e o segundo item é relacionado à

\footnotetext{
20 Empresas negligenciadasa são aquelas que recebem pouca/nenhuma cobertura de analistas e da imprensa financeira e/ou aquelas empresas que têm ações com baixa liquidez na Bolsa. Parte deste "desinteresse" do mercado decorre do mal desempenho passado da empresa.
} 
alavancagem da empresa (que reflete o risco financeiro). Para melhor entender o efeito relatado por Penman et al (2007), considere a seguinte apresentação do balanço patrimonial da empresa:

\begin{tabular}{ll}
\hline \multicolumn{2}{c}{ Balanço Patrimonial } \\
\hline Operacional & Financeiro \\
\hline Ativo Operacional & Passivo Financeiro \\
(-) Passivo Operacional & $\frac{(-) \text { Ativo Financeiro }}{}$ \\
& $=$ Dívida Líquida \\
& $+\mathrm{PL}$ \\
\hline Ativo Operacional Líquido & Dívida Líquida $+\mathrm{PL}$ \\
\hline
\end{tabular}

Assim, o valor contábil das operações da empresa é o valor do ativo operacional líquido (AOL), que é representado pela diferença entre o ativo operacional $(A O)$ e o passivo operacional $(P O)$. O $P O$ é decorrente de negociações com os clientes e fornecedores no curso normal das operações da empresa (exceção para a captação de recursos para as atividades operacionais). Exemplos de $P O$ seriam os fornecedores, as contas a pagar, as receitas diferidas, os passivos com fundos de pensão e os passivos relacionados às despesas incorridas. O valor da dívida líquida $(D L)$ é a diferença entre os passivos financeiros da empresa decorrentes de algum tipo de financiamento/empréstimo $(P F)$ e seus ativos financeiros $(A F)$, considerados como os caixa e equivalentes e investimentos em títulos e valores mobiliários. A equação fundamental do balanço faz com que o valor do patrimônio líquido $(P L)$ seja expresso por: $P L=A O L-D L$. Assim, o preço da ação $(P)$ é igual à diferença entre o valor de mercado das operações $\left(P^{A O L}\right)$ e o valor de mercado da dívida $\left(P^{D L}\right)$, ou seja, $P=P^{A O L}-P^{D L}$. Portanto, a diferença entre o valor de mercado do $P L$ e o valor contábil do $P L$ pode ser representada por:

$$
P-P L=\left(P^{A O L}-A O L\right)-\left(P^{D L}-D L\right)
$$

Partindo-se da premissa de que o valor contábil da dívida líquida é igual ao seu valor de mercado (e quanto mais a mensuração contábil deste tipo de operação utilizar o conceito de fair value, mais esta premissa está próxima da realidade $\left.{ }^{21}\right)$, tem-se que $P-P L=\left(P^{A O L}-A O L\right)$. Contudo, embora a diferença entre o valor de mercado e do valor contábil do $P L$ não seja afetada pela alavancagem, o índice PL/P o é. Penman et al (2007) apresentam esta relação por:

\footnotetext{
${ }^{21}$ Vale salientar que de acordo com as normas atuais do IASB e do FASB há a possibilidade de passivos financeiros serem avaliados pelo seu fair value (fair value option).
} 


$$
\begin{aligned}
\frac{P L}{P} & =\frac{A O L}{P}-\frac{D L}{P} \\
& =\frac{P^{A O L}}{P} \times \frac{A O L}{P^{A O L}}-\frac{D L}{P} .
\end{aligned}
$$

Como parte-se da premissa que a dívida líquida é mensurada pela contabilidade a valores próximos de seu valor de mercado, então $P=P^{A O L}-D L$. Assim, $P^{A O L} / P-D L / P=1$. Finalmente, pode-se escrever:

$$
\begin{aligned}
& \frac{P L}{P}=\left(1+\frac{D L}{P}\right) \times \frac{A O L}{P^{A O L}}-\frac{D L}{P} \\
& \therefore \frac{P L}{P}=\frac{A O L}{P^{A O L}}+\frac{D L}{P} \times\left(\frac{A O L}{P^{A O L}}-1\right)
\end{aligned}
$$

Com esta decomposição do índice PL/P, percebe-se que este é uma média ponderada do índice $\mathrm{PL} / \mathrm{P}$ dos ativos operacionais da empresa e do índice PL/P das atividades de financiamento da empresa. Portanto, se os retornos esperados associados aos efeito PL/P são recompensas pelo risco, estes benefícios estão associados com o risco operacional, mensurado por $A O L / P^{A O L}$ e pelo risco financeiro, mensurado pela alavancagem de mercado DL/P (PENMAN et al, 2007). A análise empírica realizada por Penman et al (2007), demonstra que os retornos subseqüentes das ações relacionam-se positivamente com o componente representante do risco operacional, mas relacionam-se negativamente com o componente do risco financeiro da empresa. Entretanto, a explicação do porquê isso ocorre não é fornecida e para Piotroski (2007) esta é principal fraqueza do trabalho de Penman et al (2007) e deverá ser objeto de projetos de pesquisas futuras.

Outras pesquisas focam na utilidade da análise fundamentalista. Kothari (2001, p.171) comenta que a principal motivação da pesquisa em análise fundamentalista (e do seu uso na prática) é a identificação de títulos mal precificados com o propósito de se realizar boas oportunidades de investimento. Em um trabalho clássico Ou e Penman (1989) utilizam análise de demonstrações contábeis e documentam que um conjunto de indicadores financeiros é capaz de predizer lucros futuros e os retornos das ações. Lev e Thiagarajan (1993) analisam sinais financeiros que são freqüentemente utilizados por analistas e mostram que estes sinais são correlacionados com os retornos das ações. Abarbanell e Bushee (1997) documentam que uma estratégia de investimento baseada em sinais financeiros ajuda os investidores a ganhar significantes retornos anormais. 
Com relação aos sinais contábeis específicos, Sloan (1996) encontrou evidências de que empresas com maior montante de accruals $^{22}$ têm pior desempenho no futuro. Piotroski (2000) agrega o efeito alto PL/P à análise de demonstrações contábeis e mostra que o retorno médio ganho por um investidor com posição ativa em uma carteira de empresas com alto índice PL/P pode aumentar no mínimo 7,5\% ao ano ao selecionar empresas fortes financeiramente dentro do grupo de firmas com alto PL/P. Para isso Piotroki (2000) elabora uma estratégia totalmente baseada em informações contábeis. Beneish et al (2001) utilizaram sinais baseados no mercado em conjunto com a análise de demonstrações contábeis e demonstraram que é possível diferenciar as ações com bom e mal desempenho. Recentemente Mohanram (2005) combinou a análise fundamentalista tradicional com métricas elaboradas para diferenciar o desempenho das empresas com baixo índice PL/P e também demonstrou ser possível ganhar retornos anormais ao adotar tal estratégia. Esse último resultado é controverso às explicações tradicionais da literatura de que o resultado obtido neste tipo de estratégia é função do risco das empresas com alto PL/P. Em geral os resultados da pesquisa em análise fundamentalista sugerem que a análise de demonstrações contábeis adiciona valor à estratégia de simplesmente selecionar empresas com alto PL/P. Este trabalho contribuí com a literatura ao considerar os efeitos da análise de demonstrações contábeis associada à avaliação do nível de governança corporativa das empresas.

A seguir apresenta-se uma discussão sobre os ajustes ao regime de competência - os accruals que são essenciais ao papel informativo das demonstrações contábeis. Desde o clássico trabalho de Patton e Littleton (1940) consolidou-se a idéia de que o princípio da competência seria o método mais adequado para se atingir um modelo de informação mais próximo do "ideal" econômico (LOPES, 2001).

\subsubsection{A relevância dos accruals - ajustes advindos do regime de competência}

Um dos principais alicerces da contabilidade é o regime de competência. Este é um dos fundamentos teóricos, em conjunto com o princípio da continuidade e o conservadorismo (prudência), que é amplamente difundido entre os diversos regimes contábeis ao redor do mundo e tem presença marcante nas normas emitidas pelo Financial Accounting Standards Board

\footnotetext{
${ }^{22}$ Veja item 2.2.1 para uma discussão mais aprofundada sobre accruals.
} 
(FASB) e pelo International Accounting Standards Board (IASB). O regime de competência agrega valor à informação do fluxo de caixa. Penman (2007, p.133) $\operatorname{comenta}^{23}$ :

Cash flow from operation adds value and is incorporated in the revenue and expenses. But to effect the matching of revenues and expenses, the accountant modifies cash flows from operations with the accruals. Accruals are measures of noncash value flows.

Os accruals ajustam o reconhecimento dos fluxos de caixa no tempo para que o lucro contábil reflita melhor o desempenho da empresa do que o fluxo de caixa (DECHOW e DICHEV, 2002). Martins (1999, p.14) destaca que “[...] a grande diferença entre o regime de competência da contabilidade e o regime de caixa dos fluxos financeiros puros reside na mais correta alocação, naquele, dos mesmos fluxos de entrada e saída destes". Isto significa que, ceteris paribus, no longo prazo o fluxo de caixa e o lucro convergem.

Os ajustes advindos do regime de competência impactam tanto as receitas quanto os custos/despesas e podem ser classificados como accruals de receitas e accruals de despesas. Dechow e Dichev (2002) fazem o detalhamento analítico da composição dos accruals demonstrando a sua relação com os fluxos de caixa presentes, passados e futuros. Penman (2007, p. 134) apresenta as seguintes decomposições para as receitas e despesas de um período:

Receitas $=$ Recebimentos em caixa das vendas (receitas) no período + Novas vendas (receitas) a prazo - Recebimentos em caixa das vendas (receitas) de períodos anteriores - Estimativa de vendas (receitas) do período que não serão recebidas - Receitas diferidas de caixa recebido antecipadamente à venda + Receita previamente diferida para o período atual

Despesas $=$ Despesas em caixa no período + Despesas incorridas na geração de receitas do período que ainda não foram pagas - Pagamentos em caixa para a geração de receitas futuras + Pagamentos que foram realizados no passado para gerar receitas no período atual

\footnotetext{
${ }^{23}$ Tradução Livre: O fluxo de caixa das operações adiciona valor e é incorporado nas receitas e despesas. Entretanto, para reconhecer as receitas e despesas de acordo com o regime de competência, o contador modifica os fluxos de caixa das operações com os ajustes decorrentes do regime de competência (accruals). Estes ajustes são medidas nãomonetárias de fluxos de valor.
} 
A definição de acrruals pode ser entendida como a diferença entre o lucro líquido do período e o fluxo de caixa operacional do período. Os accruals alteram o período de reconhecimento do valor nas demonstrações contábeis. No caso de uma venda (ou outra receita) que é reconhecida no período, mas que só será recebida no futuro, há uma diferença positiva do lucro em relação ao fluxo de caixa do período. Já no caso de aquisição de ativo imobilizado, o reconhecimento no resultado, através da depreciação, será posterior ao impacto no fluxo de caixa, gerando um accrual negativo. As diferenças entre os valores que impactam o lucro e o fluxo de caixa podem ser bastante significativas na prática e a Tabela 1 apresenta os ajustes ao regime de competência para as empresas mais representativas da Bovespa ${ }^{24}$ para as demonstrações contábeis referentes ao ano de 2006.

Tabela 1. Accruals das principais empresas componentes do IBOVESPA

\begin{tabular}{|c|c|c|c|c|}
\hline Exercício findo em 31/12/2006 & $\begin{array}{c}\text { PETROBRAS } \\
\text { R\$ Milhões }\end{array}$ & $\begin{array}{c}\text { CVRD } \\
\text { R\$ Milhões }\end{array}$ & $\begin{array}{c}\text { USIMINAS } \\
\text { R\$ Milhões }\end{array}$ & $\begin{array}{c}\text { TELEMAR } \\
\text { R\$ Milhões }\end{array}$ \\
\hline Lucro Líquido & 25.919 & 13.431 & 2.515 & 1.310 \\
\hline - Fluxo de Caixa das Operações (FCO) & 44.125 & 13.929 & 3.822 & 5.591 \\
\hline$=$ Accruals & $(18.206)$ & $\overline{(498)}$ & $\overline{(1.307)}$ & $\overline{(4.281)}$ \\
\hline em $\%$ do FCO & $41 \%$ & $4 \%$ & $34 \%$ & $77 \%$ \\
\hline
\end{tabular}

Fonte: Economatica

Apesar da Tabela 1 demonstrar o percentual dos accruals em relação ao fluxo de caixa das operações, é importante ressaltar que esta medida deve ser interpretada cuidadosamente ao se avaliar o montante relativo dos ajustes. Isto porque devido à característica dual dos lançamentos contábeis, os ajustes positivos podem eliminar os ajustes negativos. Assim, uma análise mais detalhada se faz necessária para identificar qual empresa apresentaria maiores ajustes relativos ao regime de competência.

A importância dos accruals reside na sua relevância adicional à medida do fluxo de caixa. Muitos estudos documentam os benefícios do regime de competência, demonstrando que o lucro é uma métrica mais adequada de performance do que os fluxos de caixa (DECHOW, 1994; DECHOW et al, 1998; LIU et al, 2002). Apesar disto, deve-se lembrar que os accruals podem ser manipulados com o intuito dos gestores anteciparem/postergarem resultados positivos (ou mesmo negativos) em benefício próprio. Este processo ficou conhecido na literatura contábil como gerenciamento de resultados (earnings management). Martinez (2001, p.43) destaca três

\footnotetext{
${ }^{24}$ Bolsa de Valores de São Paulo. As empresas apresentadas são as quatro mais representativas (não-finanaceiras) do IBOVESPA para a carteira de maio a agosto de 2007.
} 
modalidades de gerenciamento de resultados: i) para aumentar ou diminuir os lucros, ii) para reduzir a variabilidade do lucro e, iii) para reduzir lucros correntes em prol de lucros futuros.

Em um trabalho relevante Sloan (1996) demonstrou que os investidores não avaliam corretamente os componentes dos accruals no preço das ações e apresentou uma estratégia de investimentos para o mercado norte americano que gera retornos anormais e que se baseia em uma posição comprada em ações de empresas posicionadas no menor decil dos accruals e vendida em ações de empresas posicionadas no maior decil dos accruals. Esse fenômeno ficou conhecido na literatura contábil como "anomalia dos accruals", onde os investidores superestimam os accruals e subestimam os fluxos de caixa ao formar suas expectativas sobre os lucros futuros. Bradshaw et al (2001), Xie (2001) e Barth e Hutton (2004) reforçaram as evidências dessa anomalia ao demonstrar que mesmo investidores sofisticados não consideram as informações contidas nos accruals sobre os lucros futuros e que a anomalia é robusta em um conjunto diferente de amostras de empresas no mercado norte americano. Pincus et al (2007) realizaram extensa análise internacional sobre a "anomalia dos accruals" e encontraram evidências de que ela está presente em países de direito consuetudinário (common law), notadamente na Austrália, Canadá, no Reino Unido, nos Estados Unidos e também em uma amostra de empresas com ADRs domiciliadas em países onde genericamente não foi detectado a presença da anomalia. Essa evidência reforça a necessidade de se analisar especificamente as características ao nível de cada empresa em cada país (within country firm-level analysis) no sentido de que generalizações muito amplas podem levar a conclusões inconsistentes.

Interessante notar que a análise de demonstrações contábeis leva implicitamente em conta os accruals. Nesse sentido seu correto entendimento é relevante para o sucesso de uma estratégia baseada em números contábeis. Entre os indicadores utilizados na estratégia empregada neste trabalho encontra-se a idéia da anomalia dos accruals. Assim avalia-se o nível de accruals de uma empresa em determinado período, em relação à sua geração líquida de caixa.

O caso brasileiro é um exemplo de empresas imersas em um mesmo ambiente institucional representado pelo direito codificado (code law), por insider system corporate governance model $^{25}$, pela emissão de toda a normatização contábil pelo governo ou órgãos ligados ao governo e pela grande influência das regras fiscais nas demonstrações contábeis (LOPES, 2005). 
Adicionalmente, deve-se ressaltar o baixo nível de enforcement (DURNEV e KIM, 2005) do mercado brasileiro. Esse ambiente faz com que a análise da utilidade demonstrações contábeis de empresas atuantes no mercado brasileiro seja um exercício interessante no sentido de investigar os resultados obtidos em relação aos previamente encontrados em outros países.

\subsection{Governança Corporativa}

Desde a revolução industrial ocorrida no século XVIII, e a conseqüente separação entre gestão e propriedade, mecanismos para diminuir a probabilidade de expropriação do acionista têm sido desenvolvidos. Inicialmente, auditores independentes eram voluntariamente contratados pelos acionistas para avaliar a performance dos administradores aos quais eram confiados os seus recursos (IMHOFF, 2003). Esta situação permaneceu até o colapso da Bolsa de Nova York (New York Stock Exchange - NYSE) em 1929, a partir do qual o congresso americano emitiu o Securities Act em 1933 e o Securities Exchange Act em 1934, além de criar a Securities and Exchange Commission (SEC) em 1937. Desde então todas as empresas americanas negociadas em Bolsa de Valores têm a obrigação de publicar juntamente com suas demonstrações contábeis o parecer dos auditores independentes. Os outros países seguiram na mesma linha e no Brasil o parecer do auditor independente passou a ser exigido por lei em $1968^{26}$ para as empresas que pedissem registro para emitir seus títulos e valores mobiliários no mercado de capitais e a partir de $1972^{27}$ para as empresas listadas em Bolsa.

Após a exigência legal e do mercado para que empresas que desejassem negociar seus títulos junto ao público tivessem suas demonstrações contábeis avaliadas por auditores externos, outros mecanismos começaram a emergir como forma de minimizar o conflito de agência e a assimetria informacional entre acionistas, gestores e credores. Isto se faz necessário, pois conforme comentam Jensen e Meckling (1976), quando os investidores adquirem uma participação na empresa e lá injetam seus recursos, os gestores podem utilizá-los para pagar uma remuneração excessiva a si próprios, tomar decisões de investimentos ou operacionais que são danosas aos interesses dos investidores externos, ou ainda utilizar os recursos de outras maneiras que lhes gerarão benefícios.

\footnotetext{
${ }^{25}$ Nesse tipo de sistema as assimetrias informacionais são resolvidas por canais de informação privados e não por intermédio de informação publicamente disponível.

${ }^{26}$ Resolução Bacen No 88, de 30/01/1968.

${ }^{27}$ Resolução Bacen $N^{\circ}$ 220, de 10/05/1972.
} 
Conflitos de agência também aparecem na relação entre o credor e o acionista. Isto porque ao receber um empréstimo, os gestores podem expropriar o valor obtido ao emitir títulos de dívida adicionais, ao utilizar os recursos obtidos para o pagamento de dividendos ou ao investir em projetos de alto risco (SMITH e WARNER, 1979). Nesse contexto, mecanismos formais e informais foram desenvolvidos em diferentes países de maneira a diminuir a probabilidade de expropriação dos fornecedores de recursos das empresas. A Figura 1 apresenta os mecanismos clássicos para a diminuição do conflito de agência e da assimetria informacional entre os fornecedores de recursos da empresa e seus gestores e os separa em mecanismos de governança e mecanismos de contabilidade.

Figura 1. Mecanismos de governança e contabilidade para proteção do principal

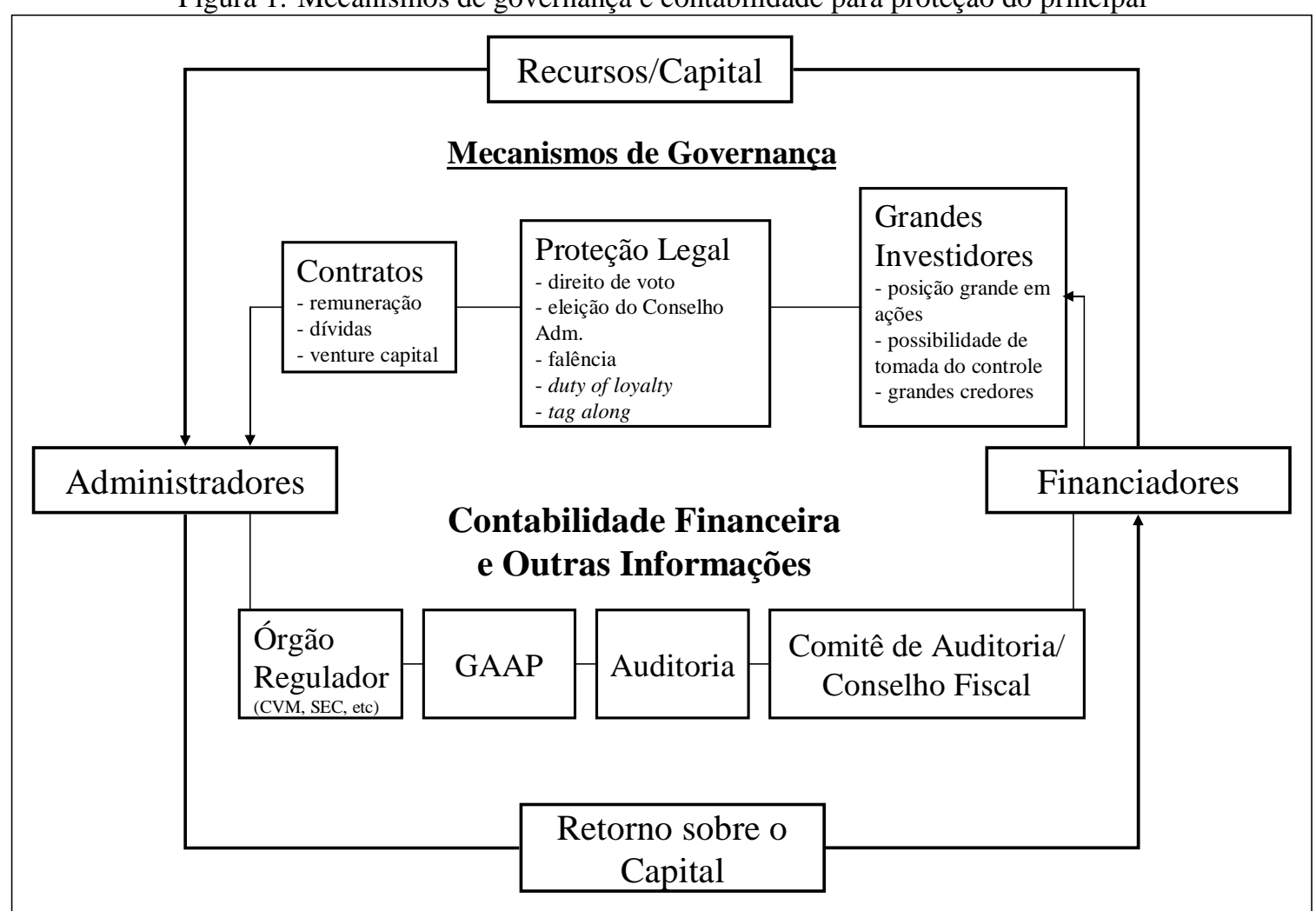

Adaptado de Sloan (2001, p.341).

Também é interessante salientar que após os escândalos contábeis e de governança ocorridos no mercado norte americano no início do século XXI e as suas conseqüências (por exemplo, a lei Sarbanes-Oxley em 2002), a pressão dos agentes reguladores sobre o nível de governança e de divulgação financeira das empresas aumentou. A pesquisa em temas que relacionam governança, transparência, disclosure voluntário, valor da empresa, custo de capital, remuneração dos executivos, nível de assimetria informacional, entre outros, também sofreu um significativo impacto na medida em que a atenção sobre o tema foi potencializada (TIROLE, 2006). 


\subsubsection{A pesquisa em Governança Corporativa}

A pesquisa em governança é interdisciplinar por natureza, baseando-se fortemente nos conhecimentos de economia, finanças, direito e administração (SLOAN, 2001, p.337). No meio acadêmico, o tema foi inicialmente abordado por Berle e Means (1932) em um livro que documenta a separação entre propriedade e controle nas empresas norte americanas. Posteriormente, Spence e Zeckhauser (1971) e Ross (1973) investigaram o alinhamento do interesses entre acionistas e gestores através de políticas de remuneração e incentivos aos gestores, tema que passou a ser um dos mais difundidos na pesquisa em governança. $\mathrm{O}$ trabalho clássico de Jensen e Meckling (1976) conceitua a firma como uma ficção legal que possibilita um processo complexo no qual os interesses conflitantes dos indivíduos/organizações são colocados em equilíbrio dentro de um conjunto de relações contratuais.

Posteriormente muitos trabalhos passaram a abordar o tema com uma visão econômica, e a premissa atual da moderna teoria de finanças corporativas é que os agentes internos à empresa não agem, necessariamente, de acordo com os melhores interesses dos fornecedores de capital (TIROLE, 2006, p.15).

Nesse ambiente, algumas questões interessantes no âmbito da interação entre governança e a pesquisa em contabilidade e finanças se colocam, como por exemplo:

- Os arranjos de governança corporativa influenciam o valor de uma empresa?

- Existe relação entre o nível de governança e o custo de capital das empresas?

- Os mecanismos de governança que influenciam a qualidade da contabilidade ou viceversa?

- Empresas com melhor nível de governança diminuem a assimetria informacional?

- A utilidade da análise de demonstrações contábeis é condicional ao nível de governança da empresa?

Um dos objetivos deste trabalho é contribuir com evidências a respeito da última questão apresentada. Contudo, para se entender melhor a possível relação entre governança e a utilidade de análise de balanços, faz-se necessário o entendimento da: (i) relação entre governança e o valor de uma empresa e (ii) associação entre o nível de governança e a assimetria informacional 
existente entre a empresa e seus fornecedores de recursos. A próxima seção apresenta as principais pesquisas relacionando estes temas.

\title{
2.3.2 Governança Corporativa e o Valor das empresas
}

Shleifer e Vishny (1997) argumentam que o fator-chave constituinte dos arranjos de governança corporativa nas empresas é a proteção legal. A diferença institucional entre os países é um elemento importante para explicar os arranjos de governança (e sua efetividade), considerando-se que em alguns mercados a regulamentação mínima (exigida por lei) e/ou os costumes favorecem os fornecedores de recursos em relação a outras jurisdições e, que também, a interpretação da justiça com relação a disputas legais envolvendo questões relacionadas à expropriação de recursos é diferenciada. Ainda segundo Shleifer e Vishny (1997), o direito mais importante que os acionistas podem ter é o voto, pois este faz uma convergência entre o direito ao fluxo de caixa e o direito ao controle. Gompers et al (2003, p.107) comentam ${ }^{28}$ :

\begin{abstract}
Companhias abertas são como repúblicas. A autoridade fica com os que têm direito a voto (acionistas). Estes votantes elegem seus representantes (conselheiros), os quais delegam a maioria de suas decisões para os burocratas (gestores). Como em qualquer república, o verdadeiro compartilhamento de poder depende de regras específicas de governança. Um extremo, que se inclina à democracia, fornece pouco poder para o gestor e permite que os acionistas alterem rapidamente e facilmente seus conselheiros. O outro extremo, que se inclina à ditadura, dá poder excessivo aos gestores e impões restrições para a mudança dos conselheiros. Presumivelmente, os acionistas aceitam restrições dos seus direitos com a esperança de maximizar sua riqueza, mas pouco se conhece sobre o equilíbrio ideal entre os poderes. De um ponto de vista teórico não há uma resposta óbvia.
\end{abstract}

A literatura encontrou fortes evidências de que a estrutura legal dos países (e até mesmo Estados) afeta o valor das empresas. La Porta et al (2002) mostram que o valor das empresas é positivamente associado com os direitos dos acionistas minoritários e que empresas que atuam em países de direito consuetudinário (common law) têm maior valor de mercado (com base no Q de Tobin) do que empresas atuantes em países de direito codificado (civil law). Ainda no quesito mais amplo de governança, Daines (2001) relata que empresas submetidas às leis do estado de

\footnotetext{
${ }^{28}$ Tradução Livre de: "Corporations are republics. The ultimate authority rests with voters (shareholders). These voters elect representatives (directors) who delegate most decisions to bureaucrats (managers). As in any republic, the actual power-sharing relationship depends upon the specific rules of governance. One extreme, which tilts toward a democracy, reserves little power for management and allows shareholders to quickly and easily replace directors. The other extreme, which tilts toward a dictatorship, reserves extensive power for management and places strong restrictions on shareholders' ability to replace directors. Presumably, shareholders accept restrictions of their rights in hopes of maximizing their wealth, but little is known about the ideal balance of power. From a theoretical perspective, there is no obvious answer".
} 
Delaware $^{29}$ têm maior valor de mercado do que outras empresas norte americanas. Outro ponto importante é o entendimento de como mecanismos de governança corporativa afetam as características do mercado de ações. Morck et al (2000) mostram que os preços das ações refletem menos informações específicas das empresas em países com menor proteção legal e com menos direitos aos investidores.

Também há evidências de que diferenças de governança específicas entre as firmas estão associadas com diferenças em seu valor de mercado. Black et al (2003) mostram que a governança corporativa impacta o valor das empresas (com base em múltiplos de mercado) mesmo dentro de um determinado país. Gompers et al (2003) mostram evidências de que empresas com alto índice $\mathrm{G}$ (que representam empresas com governança fraca) eram negociadas com um desconto maior do que empresas com boa governança em 1990, e que este desconto aumentou consideravelmente no ano de 1999. Anderson et al (2004) relatam que o custo de capital de terceiros é negativamente relacionado com a independência e com o tamanho do Conselho de administração. Lambert et al (2007) apresentam um modelo demonstrando que maior qualidade na informação contábil que reduz a possibilidade de expropriação de fluxo de caixa pelo gestor faz com que haja uma queda no custo de capital da empresa, fazendo com que este se mova para a taxa livre de risco. Ashbaugh et al (2006) analisam o impacto da governança no rating das empresas e documentam que mesmo após controlar por características específicas das empresas, os ratings de crédito são negativamente associados com o número de grandes acionistas e com o poder do CEO, e positivamente relacionados com as defesas de aquisições hostis, com a qualidade dos accruals, com a tempestividade (timeliness) do lucro, com a independência do Conselho, com a quantidade de ações da empresa possuídas pelos Conselheiros e com o conhecimento do Conselho. Brown e Caylor (2006) encontram uma relação positiva e significante entre governança (utilizando métricas internas e externas de governança) e preço (mais especificamente $\mathrm{Q}$ de Tobin). Essas evidências dão suporte à idéia de que melhores arranjos de governança corporativa no nível das empresas estão associados a um maior valor de mercado. Adicionalmente, o presente trabalho apresenta um modelo analítico simplificado, onde se explicita a relação entre governança e preço ${ }^{30}$.

\footnotetext{
${ }^{29}$ Daines (2001, p. 526) relata que a lei societária Delaware é a mais importante dos Estados Unidos. Mais de 50\% das companhias abertas americanas estão lá sediadas. Delaware é o único estado com uma corte (tribunal) especializada em resolver disputas sobre questões societárias e suas leis são atualizadas rapidamente de acordo com as necessidades das empresas e as mudanças do ambiente econômico.

${ }^{30}$ Veja seção 3.
} 
Com relação aos retornos de ações de empresas com diferentes níveis de governança, as evidências não são tão claras. Gompers et al (2003) demonstraram que uma carteira comprada em ações com alta governança e vendida em ações com baixa governança obteve em um retorno anormal de 8,5\% ao ano de 1990 a 1999. Cremers e Nair (2005) também encontram um resultado positivo para uma carteira comprada em empresas mais vulneráveis a aquisições em relação às empresas menos vulneráveis (métricas externas de governança). Entretanto, Core et al (2006) obtiveram resultados que não dão suporte à hipótese de que empresas com governança mais fraca tenham piores retornos nas suas ações. Core et al (2006) replicaram a carteira de Gompers et al (2003) para um período estendido e realizaram diversos testes adicionais para chegar a esta conclusão. Uma das conclusões apresentadas por Core et al (2006) é que os resultados encontrados dão suporte à argumentação de Cremers e Nair (2005) de que os retornos anormais são decorrentes de riscos ou outros fatores que estão correlacionados com governança. O presente trabalho aborda esta questão ao buscar fatores que explicam o retorno anormal de empresas e que estão relacionados tanto ao índice de governança, quanto ao efeito PL/P.

Algumas das críticas adicionais ao trabalho de Gompers et al (2003) e posteriores que utilizaram o G-Index (índice de governança corporativa desenvolvido pelo Investor Responsibility Research Center - IRRC) residem no fato de que o índice é focado na proteção de aquisições hostis e não contempla outros fatores inerentes ao conceito de governança corporativa. Nesse contexto o presente trabalho insere-se na discussão ao utilizar um recém desenvolvido índice de governança (LOPES e WALKER, 2008) e que congrega 4 dimensões consideradas relevantes na literatura (ASHBAUGH et al, 2006) e na prática do mercado (STANDARD \& POOR'S, 2002): (i) disclosure, (ii) estrutura acionária, (iii) composição do conselho e (iv) direitos dos acionistas.

Uma pergunta interessante a ser feita é: Por que todas as empresas não praticam boa governança considerando-se as evidências de aumento do seu valor? Core et al (1999) encontram evidências que os gestores das empresas têm certos benefícios quando a empresa tem governança fraca. Os autores encontraram evidências de que CEOs com maior poder sobre o Conselho de Administração ou mais protegidos, ganham maiores salários (controlando-se por outros fatores econômicos determinantes das remunerações). Ashbaugh et al (2006) argumentam que é racional que os gestores resistam aos esforços de se melhorar a governança da empresa dado que eles têm maiores benefícios (recebem uma maior remuneração) mesmo quando se considera os impactos do aumento do custo de capital de terceiros decorrente da governança mais fraca. 
Adicionalmente, os autores completam dizendo que várias fricções no mercado relativas ao controle acionário, como as cláusulas de proteção de venda do controle (poison pills ${ }^{31}$, golden parachutes $^{32}$, entre outras) contribuem e permitem um salário superavaliado e a persistência de estruturas de governança não ótimas.

\subsubsection{Governança Corporativa e a Assimetria Informacional}

Intuitivamente imagina-se que a relação entre governança e assimetria informacional seja inversa, pois quanto mais fortes os arranjos de governança de uma empresa, menor deveria ser o nível de assimetria da empresa com o mercado. Girox (2006) defende a idéia de que um sistema de governança fraco é mais facilmente dominado pelo CEO, o que pode resultar em uma menor qualidade do lucro (maior gerenciamento de resultados). Contudo, a relação direta entre governança e assimetria tem sido pouco abordada na literatura. O que há, são diversos trabalhos que relatam a influência da governança corporativa no disclosure e do disclosure na assimetria informacional.

Welker (1995) investiga a relação entre políticas de disclosure e o bid-ask spread no mercado de ações e encontra evidências que políticas de disclosure bem estabelecidas diminuem o nível de assimetria e, portanto, aumentam a liquidez das ações. A idéia é que políticas de disclosure influenciam na liquidez do mercado porque investidores se protegem (na atribuição de preço) em relação à seleção adversa, e esta proteção se manifesta na forma de liquidez dos papéis da empresa no mercado.

Ajinkya et al (2005) e Karamanou e Vafeas (2005) avaliam o impacto da estrutura do Conselho de Administração na quantidade e na qualidade do disclosure das informações corporativas e encontram evidências de que empresas com Conselhos mais efetivos aumentam o seu nível de disclosure ao divulgar com mais freqüência e com maior acurácia suas projeções de lucros. Por outro lado Lobo e Zhou (2001) encontram evidências de que empresas que divulgam menos informações para o mercado são mais suscetíveis a um maior nível de gerenciamento de

\footnotetext{
${ }^{31}$ Uma cláusula que torna a aquisição hostil inviável, como, por exemplo, aquela que diz que os acionistas da empresa devem receber ações por um preço muito menor que o de mercado no caso de alteração no controle.

${ }^{32}$ Uma cláusula que guarante diversos benefícios muito altos aos executivos da empresa se houver alteração de controle e mudança da diretoria.
} 
resultados. Essas evidências sugerem que um sistema de governança corporativa de maior qualidade deveria estar associado a um menor nível de assimetria informacional.

Kanagaretnam et al (2007) abordam diretamente a relação entre governança e assimetria informacional. Para isso, os autores utilizam o bid-ask spread como métrica de assimetria para examinar a relação entre alguns atributos do Conselho que refletem a qualidade da governança da empresa e as mudanças nos níveis de assimetria perto do período de publicação dos lucros. Os resultados encontrados indicam que as alterações na métrica de assimetria são negativamente relacionados com a independência do Conselho, com sua atividade e com o percentual de ações da empresa possuídas pelos conselheiros e diretores. Adicionalmente, Kanagaretnam et al (2007) mostram que as medidas de depth ${ }^{33}$ também são positivamente e significativamente relacionadas com a estrutura do Conselho, com sua atividade e com o percentual de ações da empresa possuídas pelos conselheiros e diretores. Esses resultados mostram que empresas com melhores sistemas de governança corporativa têm menor alterações no nível de assimetria nos períodos de publicação dos resultados. Uma das justificativas para este resultado é que o monitoramento mais efetivo do Conselho em relação aos gestores deveria aumentar a qualidade das evidenciações feitas pela empresa. Assim haveria uma diminuição na variância da informação anteriormente divulgada e da variância do erro nas publicações de resultado, fazendo com que aumentos na assimetria informacional sejam menores nas datas de publicação de resultados quando a qualidade da governança é maior (KANAGARETNAM et al, 2007).

Com base nas evidências apresentadas, pode-se concluir que a utilidade da análise de balanços é influenciada em duas direções com relação ao nível de governança corporativa das empresas. A primeira idéia é que sistemas de governança mais fortes impactam positivamente a qualidade das informações contábeis, tornando-as mais críveis e menos sujeitas a gerenciamento. Neste contexto a utilidade da análise de demonstrações contábeis deveria ser maior para empresas com bons níveis de governança. Entretanto, um importante estudo de Doidge et al (2007) mostra que (i) quase toda a variação nos índices de governança entre as empresas dos países menos desenvolvidos é atribuída às características do país (principalmente legais de proteção do investidor minoritário e de desenvolvimento do mercado) ao invés de características específicas das empresas normalmente utilizadas para explicar as escolhas de governança e que (ii) o acesso

\footnotetext{
${ }^{33}$ Representa a diferença no número de ações ofertadas para o número de ações demandadas.
} 
ao mercado global aumenta os incentivos das empresas para melhorarem sua governança, mas diminui a importância das proteções legais aos investidores minoritários no país de origem. Adicionalmente, os autores relatam que em países menos desenvolvidos, os incentivos para a empresa melhorar seu nível de governança são baixos porque o financiamento externo é caro e a adoção de melhores mecanismos de governança também é cara. Assim, no caso brasileiro, espera-se que as empresas com acesso ao mercado internacional tenham melhores mecanismos de governança.

Contudo, a assimetria de informações é menor para estas empresas (e o preço é maior), portanto o mercado é mais eficiente com relação ao seu preço. Em mercados eficientes, não é possível obter ganhos anormais com base em informações públicas (análise de balanços). Nesse contexto, conjectura-se que a análise de balanço será mais efetiva entre as empresas com menor nível de governança no mercado brasileiro. Este trabalho aborda diretamente esta hipótese.

A seguir, apresentam-se as principais características do mercado de capitais brasileiro com relação ao seu desenvolvimento e às características de seu modelo contábil.

\subsubsection{Mercado de Capitais e o modelo contábil brasileiro}

Diversos fatores tornam o Brasil um país interessante para o estudo da utilidade de estratégias de investimento em ações baseadas na análise das demonstrações contábeis. Estes fatores podem ser resumidos em três categorias: (i) qualidade dos números contábeis, (ii) eficiência do mercado de capitais brasileiro e, (iii) turbulência macroeconômica.

\section{Qualidade dos números contábeis}

Ali e Hwang (2000) documentam cinco fatores que estão relacionados com a relevância dos números contábeis para os investidores do mercado de capitais. São eles: (i) mercado orientado aos bancos ou aos investidores, (ii) tipo de regulamentação, (iii) influência das regras fiscais, (iv) concentração acionária e (v) gastos com auditoria. Segundo Lopes (2005), o Brasil claramente se relaciona de forma negativa com todos os fatores mencionados. De acordo com os fatores apresentados por Ali e Hwang (2000) e pelo sistema de classificação de Nobes (1998), a classificação do modelo contábil brasileiro pode ser listada como: 
a. Sistema financeiro orientado aos bancos e concentração acionária: as empresas brasileiras não dependem do mercado de capitais para financiar suas atividades ${ }^{34}$. A Tabela 2 apresentada por La Porta et al (1997b, p.1138) mostra isto. O Brasil tem um índice de capitalização externa em relação ao PNB de 0,18 enquanto este índice é de 0,58 nos Estados Unidos. O número de empresas listadas em Bolsa em relação à sua população também era bastante baixo no Brasil em 1994. Este indicador era 3,48 em relação a 30,11 nos Estados Unidos. Entre 1986 e 1996 não houve nenhuma oferta pública primária de ações no Brasil. De fato, o movimento era contrário, ou seja, as empresas estavam fechando o capital. No ano 2000 sete empresas (Agrale, White Martins, Arno, Durex Industrial, Abril, Ceval e Lojas Brasileiras) fecharam o capital. Este movimento é característico de um ambiente onde a proteção aos investidores é pobre. De acordo com Luz (2000) os acionistas controladores têm expropriado os acionistas minoritários de diferentes maneiras, incluindo a venda de ativos por valores menores que os de mercado para empresas que são possuídas ou têm relação com a matriz, com a contratação de pessoal não qualificado, com a implementação de projetos que beneficiam os executivos da empresa e com o clássico problema dos altos salários. A alta concentração acionária no mercado brasileiro tem estreita relação com o tratamento dos acionistas minoritários. Pesquisas têm mostrado que a concentração acionária funciona como substituta para mecanismos de governança para um ambiente de pouca proteção aos investidores (SHELEIFER e VISHNY, 1997), considerando-se que diminuí o conflito de agência. De acordo com os dados da Economatica (GAZETA MERCANTIL, 2000) 95\% de todas as empresas negociadas na Bovespa têm 3 ou menos acionistas com $50 \%$ ou mais de ações com direito a voto. Esta estrutura do mercado de capitais brasileiro reduz a relevância dos números contábeis porque eles deveriam servir como redutores da assimetria informacional. Com base nestas evidências e na classificação sugerida por Nobes (1998), o Brasil pode ser considerado um país classe B, pois não tem um modelo orientado ao mercado de capitais.

b. Normatização contábil emitida pelo governo: a normatização contábil das Sociedades Anônimas no Brasil é dada originalmente pela Lei 6.404/76 (Lei das S/A), recentemente complementada e alterada pela Lei 11.638/07, cabendo à CVM (Comissão de Valores Mobiliários) normatizar assuntos específicos para as companhias abertas. É importante salientar

\footnotetext{
${ }^{34}$ A partir de 2004 as empresas brasileiras passaram a acessar mais constantemente o mercado de capitais. Houve um salto na captação via emissão de ações de R\$ 230 milhões no ano de 2003 para mais de R\$ 25 bilhões no ano de 2007. Contudo os números ainda são mais baixos do que em países com mercado de capitais forte. Vale ressaltar que
} 
que o processo de normatização da contabilidade brasileira diferia consideravelmente dos países anglo-saxões. Nestes países, a normatização contábil era (e ainda continua sendo) emitida/estabelecida por órgão privado, enquanto no Brasil a regulamentação era advinda da Lei $6.404 / 76$ e de agências reguladoras do governo ${ }^{35}$. Outro ponto relevante sobre a influência governamental na qualidade contábil no período analisado se refere à atuação da Secretaria da Receita Federal (SRF). Todas as empresas brasileiras devem seguir as normas da SRF para a apuração e recolhimento dos impostos. Muitas vezes a influência das leis fiscais nos procedimentos contábeis distorciam a realidade econômica das empresas. Finalmente, vale dizer que já houve casos de intervenção governamental de maior escala, como a ocorrida no episódio da maxidesvalorização do Real em 1999. Naquele ano, o Ministério da Fazenda autorizou o diferimento das perdas com a variação cambial (este procedimento não era permitido sob as regras da CVM, que abriu exceção para este episódio específico). Nesse contexto, o Brasil se enquadra como um país classe B de acordo com a classificação de Nobes (1998). Conforme apresentado em Ali e Hwang (2000) as características apontadas tendem a reduzir a relevância dos números contábeis no Brasil.

c. Modelo Continental: Nobes (1998) discute o conceito de países auto-suficientes e de países dominados culturalmente. Assim como outros países da América do Sul (antigas colônias espanholas e portuguesas), o Brasil é culturalmente dependente e adota o chamado modelo continental, conforme comentado por Anderson (1999). Costa (1993) - o primeiro presidente da CVM - relata que os relatórios anuais publicados pelas empresas brasileiras não são publicados para informar os investidores, mas sim para cumprir as normas (país classe B). Novamente de acordo com Ali e Hwang (2000), este aspecto deve impactar negativamente a relevância dos números contábeis no Brasil.

d. Influências das Regras Fiscais na Contabilidade Societária: durante o período estudado ${ }^{36}$ pode-se dizer que a legislação fiscal no Brasil exerceu uma forte influência sobre as demonstrações contábeis publicadas. Segundo o Decreto $n^{\circ} 3.000$ de 26/03/1999, o imposto de

pela característica deste estudo (analisar retornos até 2 anos à frente), os dados das demonstrações financeiras se referem até dezembro de 2004.

${ }^{35}$ Com a lei 11.638/07 abriu-se espaço para a criação de um órgão privado (o Comitê de Pronunciamentos Contábeis - CPC) para a emissão de pronunciamentos contábeis que possam ser adotados pela CVM.

${ }^{36}$ Ressalta-se que a partir do exercício de 2008, com as com as alterações advindas da lei 11.638/07, a contabilidade societária poderá ser escriturada independentemente da contabilidade fiscal das empresas, diminuindo, em tese, as influências das regras fiscais na Contabilidade Societária. 
renda a pagar pelas pessoas jurídicas com obrigatoriedade de manter escrituração contábil é calculado com base no lucro real ${ }^{37}$, cuja definição é dada pela Receita Federal de maneira que sejam aceitas algumas adições e exclusões ao lucro contábil. Um exemplo desta influência se faz presente na estimativa das despesas com depreciação. Conforme relatado em Iudícibus et al (2007, p.222), a tendência de um número significativo de empresas é simplesmente adotar as taxas de depreciação admitidas pela legislação fiscal. Os ajustes no LALUR podem gerar custos que as empresas querem evitar. Mesmo que a vida útil do bem seja diferente, as empresas optam pelas taxas fiscais de maneira a não serem impactadas pelas limitações do Fisco. Isto porque a interpretação da Receita Federal é que somente podem ser deduzidas para fins fiscais as despesas que tenham sido assim registradas na contabilidade (IUDÍCIBUS et al, 2007, p.222). Outros casos como a avaliação de estoques, as operações de arrendamento mercantil, os juros sobre capital próprio, entre outros, podem ser citados. Neste caso o Brasil se enquadra claramente, de acordo com a classificação de Nobes (1998), como país classe B.

Em resumo, pode-se dizer que o regime contábil brasileiro - durante o período analisado neste trabalho - não é estruturado com os incentivos corretos para a geração e divulgação de informações relevantes aos usuários externos à empresa. De modo geral, as demonstrações contábeis brasileiras são preparadas para o cumprimento das regras fiscais e das regulamentações governamentais. Não há uma demanda por demonstrações contábeis informativas, pois as empresas não se financiam prioritariamente com base no mercado de capitais. Os bancos fornecem os recursos às empresas e demandam informações específicas. Também, pode-se dizer que o maior nível de conflito de agência no caso brasileiro não ocorre entre os acionistas e gestores (problema de agência tipo I), mas sim entre os acionistas controladores e os minoritários (problema de agência tipo II). A existência de dividendos obrigatórios cria incentivos para essa situação. O artigo 202 da lei 10.303/01 relata que os acionistas têm direito de receber como dividendo obrigatório, em cada exercício, a parcela dos lucros estabelecida no estatuto ou, se este for omisso, a metade do lucro líquido do exercício diminuído ou acrescido da constituição da reserva legal e da constituição/reversão da reserva para contingências. Estas exigências têm o intuito de proteger os acionistas minoritários, contudo podem criar incentivos para os gestores subestimarem os lucros. As regras fiscais também exercem forte influência na contabilidade

\footnotetext{
${ }^{37}$ Apurado no livro fiscal denominado LALUR - livro de apuração do lucro real.
} 
societária, podendo distorcer consideravelmente a realidade econômica divulgada nas demonstrações contábeis da empresa.

Adicionalmente, no período avaliado, pode-se dizer que havia um alto nível de discricionariedade dos gestores brasileiros sobre as políticas contábeis (reavaliação de ativos permanentes, capitalização de pesquisa e desenvolvimento, entre outros) e que estes estavam expostos a uma fiscalização menos rigorosa que os seus pares internacionais em países mais desenvolvidos. Borba e Murcia (2005) comentam que no período de 2001 a 2004 houve apenas 18 republicações de balanços exigidas pela CVM. No mesmo período houve 1.724 republicações de balanços de empresas americanas exigidas pela SEC e, em 2005, um significativo aumento para 1.195 republicações no ano (TURNER e WEIRICH, 2006). Neste ambiente de diferentes características do regime contábil brasileiro (em relação a mercados desenvolvidos), torna-se relevante a investigação da utilidade da análise de balanços para a elaboração de estratégias de investimento em ações.

\section{Eficiência do mercado de capitais brasileiro}

Não há um consenso na literatura se o Brasil tem um mercado de capitais eficiente da forma semi-forte ou eficiente da forma fraca. Karemera et al (1999) encontraram evidências que a Argentina, o Brasil e o México têm mercados eficientes da forma fraca do ponto de vista do investidor internacional, enquanto o Brasil e o México também têm mercados eficientes da forma fraca fazendo-se a análise em moeda local. Ojah e Karemera (1999) sugerem que a Argentina, o Brasil e o Chile têm mercados eficientes da forma fraca. No entanto, Haque et al (2001) não encontrou evidências, a partir de testes das proporções de variâncias dos retornos semanais, de que estes mercados são eficientes da forma fraca. Ratner e Leal (1999) mostram que não há evidências de que uma estratégia de investimentos baseada em informações de preços passados resulte em retornos anormais. Da Costa (1994) documenta que o processo de reversão de preços no Brasil é maior do que o nos Estados Unidos.

Alguns trabalhos específicos para o mercado brasileiro (SCHIEHLL, 1996; PEROBELLI e NESS, 2000; PROCIANOY e ANTUNES, 2001) também convergem para a idéia de que este não é eficiente da forma forte. Assim, não há consenso quanto à forma de eficiência (semi-forte ou fraca) do mercado brasileiro, mas admite-se que de forma geral este tem um menor nível de eficiência que os mercados desenvolvidos. 
Alguns autores sugerem que as características de eficiência do mercado brasileiro são decorrentes da natureza de suas instituições. Algumas barreiras que limitam o desenvolvimento do mercado de capitais são discutidas por Gorga (2003) e Black (2000) e incluem: i) a CVM tem um número de funcionários muito pequeno e orçamento bastante limitado e ainda não tem sofisticação suficiente para identificar formas de disclosure que são enganosas (mis-disclosure) ou negociações que beneficiem os gestores (ou outros agentes) em relação a outros possíveis interessados, como os acionistas ou clientes (self-dealing); ii) não há promotores especializados para levar casos complexos envolvendo títulos e valores mobiliários à corte e os promotores têm uma reputação de nem sempre serem tão honestos; iii) falta sofisticação à corte; iv) o Brasil não tem, ainda, uma forte cultura de compliance com as regras de disclosure; v) há um desincentivo para as empresas que não são companhias abertas prepararem demonstrações financeiras auditadas, pois em empresas com maior controle externo é mais difícil esconder informações do fisco; vi) companhias abertas utilizam pouco a figura de Conselheiros independentes e os Conselheiros ditos independentes podem não ser tão independentes assim na prática. Adicionalmente, Durnev e Kim (2005) classificaram o Brasil como um país com regime legal pobre, transparência baixa e pouco rigor para que as normas sejam cumpridas.

Esta realidade tem um impacto misto na utilidade da análise das demonstrações contábeis. Se os mercados incorporam novas informações aos preços de maneira mais lenta, a análise de balanços tende a ser mais efetiva para antecipar a performance futura da empresa. Por outro lado, se as instituições de mercado são fracas, as demonstrações contábeis podem perder a credibilidade e, conseqüentemente, a utilidade. O resultado final da interação entre este conjunto de forças é uma questão de interesse empírico, a qual o presente trabalho aborda.

\section{Instabilidade macroeconômica}

A economia brasileira passou por diversos choques macroeconômicos nos últimos anos. Em 1994, o plano Real foi implementado de maneira a reduzir a inflação e a estabilizar o país no campo fiscal. Concomitantemente, houve uma drástica redução do Estado na economia decorrente do programa de privatização implementado. Estas alterações causaram importantes impactos no funcionamento do mercado brasileiro, considerando-se que empresas de setores regulados e controladas pelo governo foram vendidas para a iniciativa privada. Houve, também, uma onda de fusões, aquisições e liquidações e novas ações passaram a ser negociadas no 
mercado de capitais. Além desta grande mudança institucional, o Brasil foi afetado, em anos posteriores, pelas crises do México (1995), da Tailândia (1997), da Indonésia (1997), das Filipinas (1998), da Coréia (1997-8) e da Rússia (1998). Finalmente, a moeda brasileira alterou seu regime de câmbio e passou a ser flutuante em 1999, ano em que houve significativa desvalorização cambial. Mais recentemente, as crises da Turquia (2001-2), da Argentina (2002) e o processo eleitoral brasileiro (2002), também impactaram o mercado de capitais brasileiro.

A Figura 2 apresenta a volatilidade mensal do índice IBOVESPA ${ }^{38}$ desde 1994 e mostra que as crises macroeconômicas nos últimos dez anos impactaram consideravelmente a volatilidade do mercado de capitais brasileiro. Esta incerteza macroeconômica leva, potencialmente, a uma redução da utilidade da análise de demonstrações contábeis. Uma questão importante é se os eventos macroeconômicos se sobrepõem aos fundamentos das empresas. Nesse sentido, o Brasil apresenta uma oportunidade única e interessante para se testar a utilidade das demonstrações contábeis.

38 Índice representativo do percentil de $80 \%$ das ações mais líquidas negociadas na Bolsa de Valores de São Paulo. 
Figura 2. Crises macroeconômicas e a volatilidade mensal do IBOVESPA

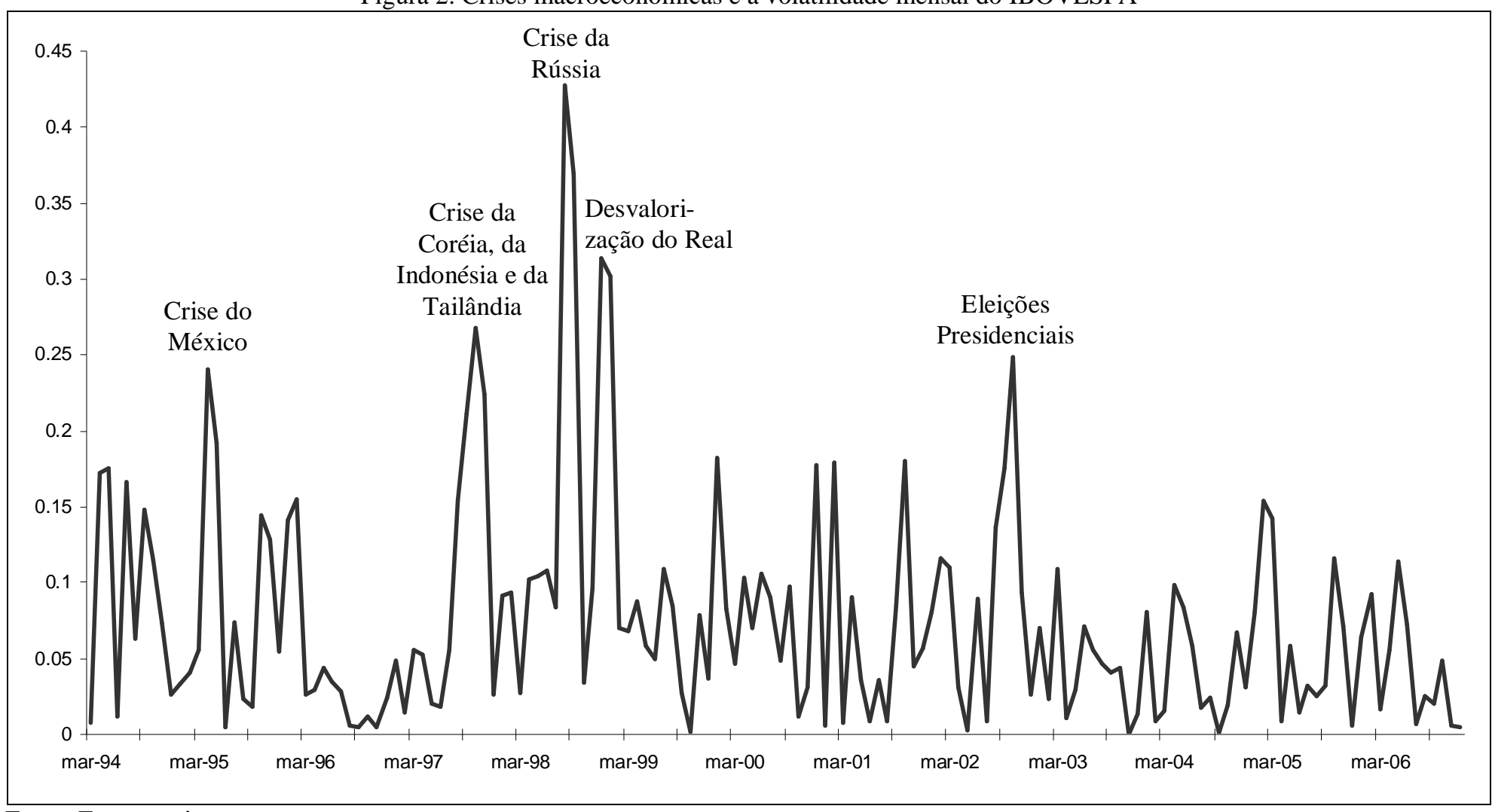

Fonte: Economatica 


\section{MODELANDO A RELAÇÃO ENTRE GOVERNANÇA E PREÇO DAS AÇÕES}

Nesta seção analisa-se o impacto dos arranjos de governança corporativa no preço das ações. Esta ligação é importante na medida em que mostra, além das evidências empíricas apresentadas na seção 2.3.2, a associação teórica positiva entre governança e preço. Demonstra-se que melhorias na governança das empresas causam um impacto positivo no preço pelo incremento do esforço do gestor (e pela diminuição do conflito de agência). Lambert et al (2007) demonstram, com base no arcabouço do $\mathrm{CAPM}^{39}$, que informações de melhor qualidade, que reduzem a expropriação dos fluxos de caixa da empresa pelos gestores, diminuem lentamente o custo de capital da empresa, fazendo-o mover para a taxa livre de risco. O modelo apresentado neste trabalho é mais genérico no sentido que não assume as premissas restritivas do CAPM e demonstra que melhorias nos sistemas de governança reduzem o custo de capital até um certo nível, pois há sempre o risco de um choque externo e também um limite para o nível de governança. Para isto parte da idéia que o risco de falência da empresa está associado ao nível de esforço dos gestores. Araujo e Funchal (2006) apresentam um modelo para demonstrar o papel da nova lei de falências no desenvolvimento do mercado de crédito. O modelo apresentado neste trabalho utiliza, também, os conceitos apresentados por Araujo e Funchal (2006), mas aplica-os para o nível de governança das empresas. Adicionalmente, pode-se argumentar que como as empresas não alteram suas práticas de governança constantemente, o impacto das alterações nas práticas de governança muda o patamar dos preços lentamente.

Estes conceitos são apresentados considerando-se um modelo simplificado que tem as seguintes características:

Premissa 1: Considere $e$ como o esforço do gestor. Assume-se que o esforço $e$ é função do nível de governança de uma firma: $e(g)=a g$ onde $e_{g}>0$.

Sistemas de governança corporativa são desenvolvidos de maneira a diminuir a probabilidade de ocorrência do problema de risco moral. Bons sistemas de governança são aqueles que impactam diretamente o nível de esforço dos gestores de maneira que estes se comportem dentro do conceito de maximizar o valor da empresa. Quando se considera o esforço, pode-se assumir que a probabilidade de sucesso de uma empresa $(p)$ aumenta com o nível de governança corporativa 
da empresa. Mais especificamente, assume-se que $p(e(g))$ é diferenciável, estritamente crescente e estritamente côncava no nível de governança, $g$, tal que $p(e(\bar{g}))<1$, onde $\bar{g}$ é o máximo nível de governança corporativa. Essa condição significa que sempre será possível o estado de falência decorrente de um choque idiossincrático, mesmo quando $g=\bar{g}$.

Adicionalmente, três premissas são colocadas: i) os credores monitoram imperfeitamente as ações relacionadas aos payoffs que a empresa gera após fazer uma captação; ii) os credores podem prever seus payoffs esperados no caso de default e; iii) os credores e a empresa são neutras ao risco. A primeira premissa se faz necessária na medida em que ela captura a informação assimétrica entre a empresa e seus credores. A segunda premissa considera que os credores profissionais têm experiência em eventos de default e a terceira se aplica adequadamente às empresas (em relação às pessoas físicas).

Considere uma empresa que tem um projeto e necessita de recursos, $I$, os quais a empresa deve captar externamente. A empresa promete pagar aos credores o montante $F^{40}$. O projeto pode tem como retorno o valor $v$ onde a empresa será solvente se $v \geq F$ e insolvente se $v \leq F$. Dois estados são possíveis no futuro, um onde a empresa é solvente e outro onde a empresa é insolvente.

Os retornos dos estados de solvência e insolvência para a empresa são $v_{\text {solv }}$ e $v_{\text {insolv }}$ respectivamente, onde $v_{\text {solv }} \geq F \geq v_{\text {insolv }}$. A probabilidade de solvência é $p(e(g))$; a probabilidade de insolvência é $(1-p(e(g)))$. Isto implica que o valor esperado do projeto é $E(v)=p(e(g)) v_{\text {solv }}+\left(1-p(e(g)) v_{\text {insolv }}\right)$, o retorno esperado condicional ao estado de solvência é $E_{\text {solv }}(v)=v_{\text {solv }}$ e o retorno esperado condicional ao estado de insolvência é $E_{\text {insolv }}(v)=v_{\text {insolv }}$.

Assumindo que o mercado de crédito é competitivo, $I$ é o maior valor que a empresa pode demandar para financiar o projeto. Considerando-se a taxa de juros livre de risco igual a zero ${ }^{41}$, a taxa de juros cobrada da empresa pelos credores é função somente do nível de risco do projeto e dos arranjos de governança corporativa da empresa.

\footnotetext{
${ }^{39}$ Capital Asset Pricing Model.

${ }^{40}$ Em termos reais.

${ }^{41}$ Essa premissa não altera os resultados da análise, mas facilita sua interpretação.
} 
Os credores emprestam $I$ e esperam receber $I\left(1+k_{d}\right) \equiv F$ em retorno. Essa expectativa pode ser escrita como:

$$
\begin{aligned}
& I=p(e(g)) F+(1-p(e(g)))\left(v_{\text {insolv }}\right) ; \\
& F=I\left(1+k_{d}\right)=\frac{I-(1-p(e(g)))\left(v_{\text {insolv }}\right)}{p(e(g))}
\end{aligned}
$$

A taxa de juros da empresa é $k_{d}=(F / I)-1$, a qual é crescente em $F$; este é o valor que a empresa deve pagar no estado de solvência. Denotando $v_{\text {insolv }}^{u}\left(v_{\text {insolv }}^{u} \in(0,1)\right)$ como o valor por unidade de investimento $(I=1)$ referente à $v_{\text {insolv }}$, também tem-se:

$$
\begin{gathered}
k_{d}=\frac{1-p(e(g))}{p(e(g))}\left[1-v_{\text {insolv }}^{u}\right] \\
\frac{\partial k_{d}}{\partial g}=a\left(-1+v_{\text {insolv }}^{u}\right) p^{\prime}(e(g)) p(e(g))^{-2}
\end{gathered}
$$

que é decrescente no nível de governança corporativa.

Proposição 1: Um maior nível de governança corporativa reduz a taxa de juros cobrada da empresa.

Um dos objetivos ex ante das empresas é o de maximizar o conjunto de opções de projetos que os credores estejam dispostos a financiar. A sociedade prefere empresas que busquem projetos com retornos esperados positivos. Assim, as empresas devem realizar projetos que geram valor. Chamando-se o bem-estar social de $W$, tem-se:

$$
W=p(e(g)) E_{\text {solv }}(v)+(1-p(e(g))) E_{\text {insolv }}(v)-I \geq 0
$$

Como a eficiência social requer um valor esperado mínimo condicional do retorno, $E_{s o l v}(\underline{v})$, fazendo-se $W=0$, tem-se:

$$
E_{\text {solv }}(\underline{v})=\frac{I-(1-p(e(g))) E_{\text {insolv }}(v)}{p(e(g))}
$$


onde $F=I-(1-p(e(g)))\left(v_{\text {insolv }}\right) / p(e(g))$ é idêntico ao lado direito da equação de $E_{\text {solv }}(\underline{v})$.

Como a equação (1) é a solução para a promessa de pagamento mínimo que a empresa deve fazer para obter o financiamento e a equação (4) é a solução para o mínimo retorno condicional esperado que é socialmente aceito, as equações demonstram que é socialmente eficiente realizar todos os projetos que os credores financiem. Assim, as empresas devedoras estarão aptas a cumprir suas promessas de pagamento nos estados de solvência, dado que a equação (1) é igual à equação (4).

Também pode-se notar que o nível de governança corporativa exerce um efeito no retorno condicional mínimo esperado no sentido de que níveis mais altos de governança diminuem as taxas de juros cobradas (veja a equação (5)) que considera o conjunto de projetos financiáveis pelos credores

$$
\frac{\partial E_{s o l v}(\underline{v})}{\partial g}=a\left(v_{\text {insolv }}-I\right) p^{\prime}(e(g)) p(e(g))^{-2}<0
$$

Até aqui se analisou o conjunto de projetos a serem financiados. Agora examina-se os incentivos para investir. A taxa de juros impõe custos esperados nas empresas, portanto o retorno esperado da empresa $E\left(R^{B}\right)$, quando ela toma recursos emprestados, se torna:

$$
\begin{aligned}
& E\left(R^{B}\right)=p(e(g))\left(v_{\text {solv }}-F\right)+(1-p(e(g)))(0) \geq 0 \\
& E\left(R^{B}\right)=p(e(g))\left(E_{\text {solv }}(v)-F\right) \geq 0 .
\end{aligned}
$$

Substituindo-se $F$ da equação (1), tem-se:

$$
E\left(R^{B}\right)=p(e(g)) E_{\text {solv }}(v)+(1-p(e(g))) E_{\text {insolv }}(v)-I \geq 0
$$

Note que a expressão (7) é a mesma que indica que o projeto é socialmente eficiente. Esta equação mantém a igualdade do retorno mínimo condicional esperado, $E_{\text {solv }}(\underline{v})$. Portanto a empresa que capta os recursos investe em todos os projetos que os credores estejam dispostos a financiar. 
Proposição 2: Um maior nível de governança corporativa aumenta o nível de equilíbrio da dívida das empresas. Assim empresas com melhor governança têm maior endividamento de longo prazo em relação às empresas com governança mais fraca.

Premissa 2: O valor de uma empresa é função dos seus dividendos futuros esperados trazidos a valor presente (PVED), dado por $P_{0}=\sum_{t=1}^{\infty} R^{-t} d_{t}$.

onde $P_{0}$ representa o valor da empresa, $R=1+r>1$ é o fator de desconto ou 1 mais o custo de capital e $d_{t}$ é o dividendo esperado na data t. Adicionalmente, utiliza-se a sequiência $0=y_{0}+R^{-1}\left(y_{1}-R y_{0}\right)+R^{-2}\left(y_{2}-R y_{1}\right)+\ldots \ldots . .$. considerando-se que $y_{t} / R^{t} \rightarrow 0$ quando $t \rightarrow \infty$. Considerando-se $y_{\tau}=E_{t}\left[\tilde{x}_{t+1+\tau}\right] / r$, sendo $\tilde{x}_{t+1+\tau}$ o lucro líquido do período $t+1+\tau$ e adicionando-se a seqüência de soma zero no PVED, tem-se o modelo desenvolvido por Ohlson (2005) e conhecido como Abnormal Earnings Growth (AEG):

$$
P_{t}=\frac{E\left[\tilde{x}_{t+1}\right]}{r}+\sum_{\tau=1}^{\infty} R^{-\tau}\left(\frac{1}{r}\left\{E_{t}\left[\tilde{x}_{t+1+\tau}+r \cdot \tilde{d}_{t+\tau}-R \cdot \tilde{x}_{t+\tau}\right]\right\}\right)
$$

Decompondo-se o líquido $\tilde{x}_{t+1+\tau}$ em duas parcelas, a do lucro operacional após o imposto de renda, $\quad$ NOPAT $=E B I T(1-T), \quad \mathrm{e}$ a despesa financeira após o benefício fiscal, FINRAT $=k_{d}(D e b t)(1-T):$

$$
\tilde{x}_{t+1+\tau}=\left(E B I T_{t+1+\tau}-k_{d_{t+1+\tau}}\left(\operatorname{Debt}_{t+1+\tau}\right)\right)(1-T)
$$

A equação (8) pode ser simplificada se adicionarmos uma suposição ${ }^{42}$. Especificamente, considere que $z_{t+1}=\gamma z_{t}, t \geq 1$ onde $\gamma \geq 1$ é algum parâmetro de crescimento presumido. Adicionalmente, $z_{t}$ refere-se à seqüência $\left(\frac{1}{r}\left\{E_{t}\left[\tilde{x}_{t+1+\tau}+r . \tilde{d}_{t+\tau}-R . \tilde{x}_{t+\tau}\right]\right\}\right)$. A dinâmica deve também presumir alguma inicialização $z_{1}>0$. Aplicando-se um pouco de álgebra a seguinte fórmula de avaliação é encontrada (OHLSON e JUETTNER-NAUROTH, 2005; OHLSON e GAO, 2006; OHLSON e LOPES, 2007):

\footnotetext{
${ }^{42}$ Ohlson e Juettner-Nauroth (2005), Ohlson e Gao (2006) e Ohlson e Lopes (2007) demonstram este procedimento.
} 


$$
P_{0}=\frac{\tilde{x}_{1}}{r} \times\left[\frac{g_{s}-g_{L}}{r-g_{L}}\right]
$$

onde $g_{s}=\frac{\tilde{x}_{2}-\tilde{x}_{1}}{\tilde{x}_{1}}+\frac{r \times d_{1}}{\tilde{x}_{1}}$ e $g_{L}=\frac{\tilde{x}_{t}-\tilde{x}_{t-1}}{\tilde{x}_{t-1}}$ quando $t \rightarrow \infty$ (assumindo pagamento integral de dividendos). O cálculo de $g_{L}$ deixa claro que esta é a taxa de crescimento do lucro líquido no longo prazo, chamada de $L T G$. Assume-se que com o decorrer do tempo o comportamento do crescimento de longo prazo do lucro das empresas seja idêntico (Ohlson e Lopes, 2007). Assim, pode-se sugerir que $g_{L}$ é o mesmo para todas as firmas. Toma-se como premissa que $g_{L} \equiv L T G$ e que este é exógeno e decorrente do comportamento futuro da economia. Assim, considerandose a Proposição 1 e a equação (10), pode-se demonstrar ${ }^{43}$ que:

$$
\frac{\partial P_{0}}{\partial g}>0
$$

Proposição 3: Um maior nível de governança corporativa aumenta o preço da ação.

Finalmente, pode-se estabelecer uma relação entre o nível de governança corporativa de uma empresa e o seu valor por meio da abordagem de informação dinâmica linear (LID) estabelecida por Ohlson (1995). Kothari (2001, p.124) comenta ${ }^{44}$ : "Umas das áreas mais promissoras de pesquisa na literatura de coeficientes de reposta ao lucro é o relacionar as propriedades de séries de tempo do lucro com determinantes econômicos como competição, tecnologia, inovação, efetividade da governança corporativa, incentivos nas políticas de remuneração, etc". Pela LID (OHLSON, 1995), tem-se:

$$
\begin{aligned}
& x_{t+1}^{a}=\omega x_{t}^{a}+v_{t}+\varepsilon_{1 t+1} \\
& v_{t+1}=\delta v_{t}+\varepsilon_{2 t+1}
\end{aligned}
$$

onde o lucro residual é calculado por $x_{t}^{a} \equiv \tilde{x}_{t}-r \cdot b_{t-1}$, em que $b$ é o patrimônio líquido da empresa. As informações não contábeis do período, mas que impactarão o lucro em períodos futuros são denominadas $v$. Os parâmetros do modelo são $\omega$ e $\delta$ e $\varepsilon_{1 t+1}$ e $\varepsilon_{2 t+1}$ têm média zero e

\footnotetext{
${ }^{43}$ Veja no Apêndice B.

${ }^{44}$ Tradução livre de: "The most promising area of research in the earnings response coefficient literature is to relate time-series properties of earnings to economic determinants like competition, technology, innovation, effectiveness of corporate governance, incentive compensation policies, etc."
} 
são não correlacionados com as outras variáveis. Adicionalmente a condição de regularidade $0 \leq(\omega, \delta)<R$ deve se manter.

Assim, pode-se demonstrar ${ }^{45}$ que:

$$
P_{t}=b_{t}+\alpha_{1} x_{t}^{a}+\alpha_{2} v_{t}
$$

onde $\alpha_{1}=\omega /(R-\omega)$ e $\alpha_{2}=R /(R-\omega)(R-\delta)$.

Para se obter $P_{t}$ em termos do lucro líquido e não do lucro residual, faz-se:

$$
P_{t}=b_{t}+\alpha_{1}\left[x_{t}-r b_{t}\right]+\alpha_{2} v_{t}
$$

Assim, tem-se que $\frac{\partial P_{t}}{\partial g}=\frac{a\left[(T-1)(v-1) d i v_{t}+(\omega /(R-\omega)) p^{\prime}(e(g))\right]}{p(e(g))^{2}}>0$.

Percebe-se que nessa visão o impacto da governança será maior ou menor de acordo com a magnitude da persistência dos lucros. Assim, pode-se estabelecer que empresas com níveis mais altos de governança tendem a apresentar preços mais altos no mercado, decorrente do maior esforço do gestor e da percepção do mercado de tal fato.

${ }^{45}$ Veja o Apêndice C. 


\section{DESENHO DE PESQUISA}

Este capítulo apresenta o desenho dos testes empíricos utilizados para avaliar o problema de pesquisa e as hipóteses levantadas na seção 1.1. Inicialmente utiliza-se a metodologia aplicada por Piotroski (2000) para se avaliar a utilidade da análise de demonstrações contábeis entre as empresas com alto índice PL/P. Presumivelmente a análise promoverá retornos anormais ao identificar empresas com bons indicadores financeiros dentre as empresas com alto PL/P. Estas empresas estariam subavaliadas pelo mercado e seriam boas oportunidades de investimento. Com esta análise pode-se comparar os resultados de estratégias de investimento baseadas em informações contábeis para mercados desenvolvidos (Estados Unidos) e mercados em desenvolvimento (Brasil). Na seqüência, aplica-se a análise para empresas classificadas com baixo nível de governança corporativa, considerando-se que o mercado é menos eficiente com relação ao preço destas empresas e que a grande forma de comunicação da empresa com o mercado é a divulgação de suas demonstrações contábeis. Empresas com bons indicadores financeiros dentre as empresas do grupo de baixa governança também deveriam proporcionar retornos anormais aos investidores.

A terceira etapa visa unificar as análises previamente realizadas no sentido de investigar se a estratégia de investimento com base em números contábeis é potencializada no grupo de empresas com alto PL/P e baixa governança. Estas empresas apresentam maior probabilidade de expropriação do acionista minoritário, se comunicam mal e são negligenciadas pelo mercado. A identificação de empresas com boas perspectivas financeiras neste grupo deveria proporcionar retornos acima dos obtidos na análise realizada nos grupos de maneira individualizada.

Finalmente, investigam-se fatores adicionais que podem contribuir para o desempenho das estratégias de investimento baseadas em análise de balanços. Alguns autores (GUAY, 2000; FAMA e FRENCH, 1996) relatam o sucesso destas análises no mercado americano como uma anomalia. O sucesso das estratégias pode estar relacionado com outros fatores que dificultem sua aplicabilidade no mercado real. Este trabalho aborda estes aspectos ao avaliar características adicionais nos grupos das empresas de alto PL/P e baixo BCGI que podem dificultar a implementação da estratégia. 


\subsection{Sinais financeiros obtidos a partir da análise de demonstrações contábeis}

Este trabalho utiliza uma versão adaptada da estratégia proposta por Piotroski (2000) que construiu um índice composto por sinais fundamentais extraídos das demonstrações contábeis. As variáveis utilizadas têm um relacionamento teórico com o bom desempenho futuro da empresa e devem ser úteis na predição da performance, especialmente para empresas financeiramente estressadas (alto índice PL/P). Fama e French (1995) mostram que na média as empresas de alto PL/P são financeiramente estressadas. Isto significa que seu lucro, fluxo de caixa, margens e indicadores de liquidez estão em declínio ou são baixos e que sua alavancagem é alta (PIOTROSKI, 2000).

Nove sinais básicos foram identificados por Piotroski (2000). Estes sinais são comumente relacionados em livros-texto de análise de demonstrações contábeis e avaliam a rentabilidade, a alavancagem/liquidez e a eficiência operacional das empresas. Este trabalho utiliza os mesmos sinais financeiros, mas faz algumas adaptações às características contábeis do mercado brasileiro (como a ausência da obrigatoriedade da publicação da demonstração do fluxo de caixa no período analisado). Cada sinal financeiro $\left[F_{k}\right]$ é classificado como "bom" ou "ruim" dependendo do impacto teórico do sinal $\mathrm{k}$ nos preços futuros das ações e na performance da empresa. Se a realização do sinal é classificada como "bom", atribuí-se uma variável indicadora igual a um $\left[F_{k}=1\right]$; se o sinal é classificado como "ruim", atribuí-se uma variável indicadora igual a zero $\left[F_{k}=0\right]$. Importante salientar que toda padronização traz limitações a uma análise, mas o índice foi utilizado de forma a se poder comparar os resultados obtidos neste trabalho com os obtidos nos trabalhos internacionais baseados na técnica desenvolvida por Piotroski (2000).

As três variáveis utilizadas para medir a rentabilidade são o retorno sobre os ativos $(R O A)$, a variação do ROA ( $\triangle R O A)$ e os accruals (ACCRUAL). O ROA é definido como o lucro líquido dividido pelo ativo total da empresa no início do exercício. Quando o ROA é positivo, considerase um "bom" sinal; caso contrário considera-se um sinal "ruim". A $\triangle R O A$ é calculada como o $R O A$ do exercício subtraída do $R O A$ do exercício anterior. Se a $\triangle R O A$ é positiva, considera-se um "bom" sinal; caso contrário considera-se um sinal "ruim". Os accruals são calculados pelo método de balanço, seguindo Sloan (1996), Mashruwala et al (2006) e Pincus et al (2006), pois no Brasil, no período em análise (1997-2004), não houve a obrigatoriedade da publicação da demonstração do fluxo de caixa. Assim os accruals representam as variações nos ativos 
circulantes (com exceção dos itens classificados como caixa e equivalentes) menos as variações nos passivos circulantes (com exceção das dívidas de curto prazo) subtraídos da depreciação do período. Este valor é padronizado pelo ativo total do início do exercício. A seguinte fórmula representa o calculo dos accruals:

$$
\text { Accruals }=\left[(\Delta \mathrm{AC}-\Delta \mathrm{Caixa})-(\Delta \mathrm{PC}-\Delta \mathrm{DCP})-\text { Deprec } / \mathrm{AT}_{\mathrm{t}-1},\right.
$$

onde $\Delta \mathrm{AC}$ é a variação do ativo circulante, $\Delta$ Caixa é a variação em caixa e equivalentes de caixa, $\triangle \mathrm{PC}$ é a variação do passivo circulante, $\triangle \mathrm{DCP}$ é a variação da dívida de curto prazo e $\mathrm{AT}_{\mathrm{t}-1}$ é o ativo total da empresa no início do período.

Se os accruals são negtivos considera-se um "bom" sinal (o fluxo de caixa do exercícios foi maior que o lucro líquido); se os accruals são positivos, considera-se um sinal "ruim". Este tratamento é consistente com Sloan (1996) que demonstra que maiores valores de accruals são sinais "ruins" de performance futura.

Os sinais utilizados para avaliar as alterações na estrutura de capital e na liquidez são $F L C$, $\triangle L I Q U I D, \triangle A L A V$ e $O F \_P U B$. Conforme Piotroski (2000), como a maioria das empresas com alto PL/P são financeiramente estressadas, assume-se que aumentos na alavancagem, diminuição na liquidez, ou ofertas públicas de ações são sinais "ruins". FLC é definido como a alteração na posição de caixa e equivalentes de caixa da empresa (fluxo líquido de caixa), padronizada pelo ativo total no início do exercício. Valores positivos de FLC são considerados "bons" finais, enquanto valores negativos são considerados sinais "ruins". Neste ponto, vale salientar que esta medida é adaptada ao mercado brasileiro e não foi utilizada diretamente por Piotroski (2000). Utiliza-se esta métrica devido à falta de publicação da demonstração do fluxo de caixa pelas empresas brasileiras. $\triangle L I Q U I D$ mensura as alterações no índice de liquidez corrente da empresa em relação ao índice do ano anterior. O índice de liquidez corrente é calculado pela divisão do ativo circulante pelo passivo circulante da empresa no final do período. Melhoria na liquidez $(\triangle L I Q U I D>0)$ representa um "bom" sinal, enquanto diminuição é um sinal "ruim". Alterações no nível de endividamento são representadas por $\triangle A L A V$. Consideram-se as dívidas de curto e longo prazo devido baixo nível de oportunidades de financiamento de longo prazo que as empresas brasileiras podem acessar, especialmente as empresas com dificuldades financeiras. Mensura-se $\triangle A L A V$ como as alterações no índice de endividamento total em relação ao ativo total 
no início do exercício. Considera-se que um aumento na alavancagem ( $\triangle A L A V)$ representa um sinal "ruim", enquanto uma diminuição representa um "bom" sinal ${ }^{46}$. A variável $O F \_P U B$ referese à captação de recursos da empresa junto ao mercado de capitais pela emissão de novas ações. A captação de recursos via emissão de novas ações é considerada um sinal "ruim" devido à pecking order theory (MYERS, 1984) que diz que as empresas priorizam o financiamento interno e dívida à emissão de ações. A não emissão é considerada um "bom" sinal. Importante salientar que no período analisado as empresas brasileiras utilizaram muito pouco a captação de recursos via emissão/venda de ações.

A eficiência operacional é mensurada por $\triangle M A R G E M$ e $\triangle G I R O$. Define-se $\triangle M A R G E M$ como a variação na margem bruta da empresa no exercício em relação à margem do período anterior. A margem bruta é calculada pela divisão do lucro bruto da empresa pelo valor da receita líquida da empresa. Uma alteração positiva $(\triangle M A R G E M>0)$ representa um "bom" sinal, enquanto uma mudança negativa representa um sinal "ruim". Finalmente, define-se $\Delta G I R O$ como a mudança no índice de giro da empresa do período atual em relação ao período anterior. O índice de giro é calculado pela divisão da receita líquida da empresa no exercício pelos seus ativos totais no início do período. Uma melhoria no giro representa um "bom" sinal, enquanto uma diminuição representa um sinal "ruim".

Finalmente, calcula-se o indicador agregado dos sinais financeiros das empresas brasileiras (BrF_SCORE) como a soma dos sinais individuais de cada empresa em cada período, ou:

$$
\begin{aligned}
B r F \_S C O R E= & F_{-} R O A+F_{-} F L C+F_{-} \Delta R O A+F_{-} A C C R U A L+F_{-} \Delta L I Q U I D \\
& +F_{-} \Delta A L A V+O F_{-} P U B+F_{-} \Delta M A R G E M+F_{-} \Delta G I R O
\end{aligned}
$$

O BrF_SCORE varia de 0 (somente sinais "ruins") a 9 (somente "bons" sinais). Espera-se que baixos valores de $B r F \_S C O R E$ indiquem empresas com pobre performance econômico-financeira e baixo retorno de suas ações, enquanto altos valores de BrF_SCORE indiquem empresas com bons prospectos econômico-financeiros e, portanto, desempenhos acima da média no retorno de suas ações. A estratégia de investimentos analisada nesta pesquisa consiste em selecionar

\footnotetext{
46 Vale ressaltar que o aumento da alavancagem não é necessariamente um mau sinal. Aqui considera-se esta hipótese partindo-se da premissa que para empresas com alto PL/P (um dos focos da análise) o aumento da alavancagem representa, na maioria das situações, um sinal "ruim". Contudo, para a implementação da estratégia é necessária esta padronização.
} 
empresas com alto $B r F \_S C O R E$. Considera-se empresas com alto BrF_SCORE aquelas que obtiveram notas no intervalo de 7 a 9, enquanto empresas com baixo BrF_SCORE são aquelas com notas menores ou iguais a 3 .

\subsection{Seleção de Grupos - índice PL/P e BCGI}

Considerando-se a realidade do mercado de capitais brasileiro e a existência de conflito de agência, assimetria informacional e diferentes níveis de eficiência do mercado com relação aos preços das ações ${ }^{47}$, a análise de demonstrações contábeis tende a apresentar diferentes níveis de utilidade para grupos específicos de empresa. Neste trabalho, analisam-se detalhadamente dois destes grupos.

O primeiro diz respeito às empresas com alto índice PL/P. Este índice é calculado como a relação entre o valor do patrimônio líquido da empresa e seu valor de mercado. De modo a replicar a realidade desta estratégia na prática do mercado de capitais, calcula-se o índice PL/P utilizandose os preços ao final de cada ano em análise e os valores contábeis referentes às demonstrações contábeis das mesmas datas. A análise utilizada neste trabalho refere-se a uma estratégia implementada anualmente, com base nas informações disponíveis no dia 01 de maio de cada ano. Esta foi a data utilizada, pois o limite legal para a publicação dos resultados anuais das empresas brasileiras é de quatro meses após o encerramento do exercício social, que para a maioria das empresas, acontece, em 31 de dezembro. A partir do cálculo dos índices PL/ P das empresas, aplica-se a classificação por quintis. Nesse contexto, classifica-se anualmente as empresas por índice PL/P, considerando-se as empresas do quinto quintil (20\% maiores índices por ano), empresas com alto índice PL/P. Este procedimento é baseado na classificação de empresas com alto PL/P realizada por Piotroski (2000) e é também é consistente com a classificação utilizada por Mohanram (2005).

O segundo grupo analisado foi selecionado com base no índice brasileiro de governança corporativa (BCGI). O BCGI é utilizado por Lopes e Walker (2008) e avalia 4 dimensões (disclosure, estrutura acionária, composição do conselho e direitos dos acionistas) para investigar a relevância da análise de demonstrações contábeis para empresas com diferentes níveis de governança. Essa metodologia é consistente com o índice de governança utilizado por Ashbaugh

\footnotetext{
${ }^{47}$ Para maiores detalhes, consulte o capítulo 2.
} 
et al (2006). As informações utilizadas para a construção do BCGI são públicas e foram obtidas junto às empresas listadas na Bovespa. Foram analisados um total de quinze itens, sendo 3 referentes ao disclosure, 4 relacionados à estrutura societária, 5 associados à composição do conselho e 3 referentes ao direito dos acionistas. As notas finais do BCGI foram padronizadas de modo a ficarem no intervalo de 0 a 1 . O anexo A apresenta em detalhes os itens analisados para a construção do BCGI.

A partir da apuração do BCGI para os anos de 1998, 2000, 2002 e 2004, classificou-se as empresas em quintis do BCGI, em cada ano, em um processo similar ao utilizado para a classificação do índice PL/P. Entretanto, no caso do índice de governança corporativa, o maior interesse da avaliação da utilidade da análise de demonstrações contábeis está nas empresas do quintil inferior, ou seja, das empresas com baixo índice de governança. Adicionalmente, vale salientar que foram utilizados os mesmos índices de governança para os períodos t e t-1. Assim, por exemplo, o BCGI apurado para o ano de 1998 foi utilizado como proxy do BCGI de 1997, considerando-se que a alteração do índice de governança por empresa é um processo que não é imediato. Este procedimento propicia uma expansão no período da amostra (1997-2004), tornado a avaliação estatística/econométrica com relação à utilidade da análise de balanços mais robusta. A Tabela 2 apresenta o número de empresas pertencente a cada grupo no período em análise (1997-2004). São 307 empresas-período classificadas com alto PL/P e 350 empresas-período classificadas com baixo BCGI.

Finalmente, analisa-se a intersecção do grupo de empresas com alto índice PL/P e baixo BCGI. Este seria o grupo onde, presumivelmente, estratégias de investimento baseadas em informações contábeis deveriam ter o maior efeito e resultar em maiores retornos. O número de empresas nesta categoria é de 91 para o período analisado (1997-2004).

Tabela 2. Número de Empresas por grupo

\begin{tabular}{ccc}
\hline $\begin{array}{c}\text { Número de empresas classificadas por quintil do índice PL/P } \\
\text { e do BCGI no período de 1997-2004 }\end{array}$ \\
\hline QUINTIL & PL/P & BCGI \\
\hline 1 & 314 & 350 \\
2 & 312 & 404 \\
3 & 310 & 306 \\
4 & 312 & 266 \\
5 & 307 & 217 \\
\hline \hline Total & 1555 & 1543 \\
\hline
\end{tabular}




\subsection{Validade do índice de governança (BCGI)}

Uma questão relevante com relação ao uso de um índice que mensura os atributos de governança corporativa das empresas é saber como ele captura os fatores que explicam as diferenças nas escolhas de governança. Um bom índice deve estar relacionado com os fatores considerados pela teoria. Doidge et al (2006) explicam as diferenças nas escolhas de governança das empresas de um mesmo país com base na necessidade de financiamento por um menor custo de capital. Contudo, conforme comentado por e Lopes e Walker (2008), a implementação de mecanismos de governança é custosa e reduz os benefícios privados do controle. Nesse contexto, espera-se que os administradores da empresa e seus acionistas controladores adotem boas práticas de governança somente quando os benefícios da adoção superarem os seus respectivos custos.

De acordo com os conceitos discutidos em Doidge et al (2006) e Lopes e Walker (2008), pode-se dizer que, conceitualmente, empresas com maiores oportunidades de crescimento buscarão mecanismos de governança mais sofisticados com o objetivo de obter financiamento externo e aproveitar essas oportunidades. Adicionalmente, espera-se que empresas com $\mathrm{ADRs}^{48}$ negociados em Bolsa, portanto sujeitas a uma regulamentação mais severa, também adotem melhores práticas de governança. Outra variável relevante para a explicação de boas práticas de governança é o tamanho da empresa, pois empresas maiores incorrem em custos relativamente menores para a adoção desses mecanismos. Finalmente, espera-se que a relação entre direito de voto (ações ordinárias) e direito a fluxo de caixa (ações preferenciais) dos acionistas controladores seja negativamente relacionada com o índice de governança, pois esta relação seria uma proxy dos benefícios privados do controle.

Lopes e Walker (2008) apresentam (Tabela 4, p.53), a relação dos conceitos anteriormente discutidos por meio da seguinte regressão:

$$
\begin{aligned}
B C G I_{i, t}=\alpha & +\beta_{1} A D R_{i, t}+\beta_{2} P T B_{i, t}+\beta_{3} \log (A S S E T S)_{i, t}+\beta_{4} \text { GROWTH }_{i, t} \\
& +\beta_{5} W E D G E_{i, t}+\boldsymbol{\beta} \mathbf{X}_{i, t}+\varepsilon_{i, t}
\end{aligned}
$$

\footnotetext{
${ }^{48}$ American Depositary Receipts níveis II e III. São recibos de ações de empresas brasileiras negociados em Bolsas norte-americanas.
} 
onde: BCGI representa o índice de governança obtido por cada empresa i no período t; $A D R$ é uma variável dummy representando se a empresa i tem ou não ações listadas em Bolsa norteamericana no período t; $P T B$ é o índice de preço da ação i no período t dividido pelo seu valor patrimonial (price-to-book); ASSETS representa o ativo da empresa i no período t; GROWTH mensura a mudança no lucro operacional da empresa i no período $t$ em relação ao período anterior, deflacionada pelo ativo em t-1; WEDGE representa a razão de direito de voto por direito de fluxo de caixa na empresa i no período t e $\mathbf{X}_{i, t}$ representa o vetor de variáveis de controle por setor e por ano.

Os resultados obtidos por Lopes e Walker (2008) corroboram a utilização do BCGI como índice que mensura os atributos de governança corporativa das empresas. O BCGI é positivamente correlacionado com as oportunidades de crescimento, com a existência de ADRs negociados, com o tamanho das empresas e com o índice price-to-book. Nesse contexto, este trabalho utiliza o BCGI como proxy de governança corporativa das empresas.

\subsection{Cálculo dos retornos}

O retorno da estratégia de investimento é calculado com base na seleção de uma carteira igualmente ponderada das empresas selecionadas nos grupos em análise com base nos resultados do BrF_SCORE. Considera-se uma estratégia de longo prazo (1 e 2 anos). Utiliza-se a estratégia buy-and-hold, ou seja, forma-se a carteira e mantém-se a posição pelo prazo estipulado (1 e 2 anos). Não há rebalenceamento antes destes prazos. Após os prazos, uma nova carteira é formada a cada ano. O retorno é calculado a partir do dia 01 de maio no ano de formação da carteira. Este procedimento é o padrão na literatura (PIOTROSKI, 2000; MOHANRAN, 2005) e garante que todas as informações das demonstrações contábeis estão disponíveis ao público no momento da formação da carteira. Este método é consistente com as regras brasileiras para que as companhias abertas publiquem suas demonstrações contábeis anuais até quatro meses após o encerramento do exercício social.

No caso de empresas que fecharam o capital e pararam de ser negociadas na Bolsa no período em análise, considerou-se o retorno de suas ações até a data de saída. A partir da data de saída, não se considera mais a empresa na formação das carteiras. 
O retorno ajustado pelo retorno carteira de mercado (daqui em diante retorno ajustado pelo mercado) foi calculado considerando-se como benchmark uma carteira de ações ponderada representativa do mercado para o mesmo período dos retornos obtidos com a formação da carteira baseada na estratégia de investimentos. Para isto utilizou-se o IBRX, índice representativo das 100 ações mais líquidas negociadas na Bovespa. Avalia-se o retorno ajustado pelo mercado para o período de um ano de manutenção da carteira e para o período de dois anos de manutenção. Os retornos foram coletados a partir de maio de 1997 até março de 2007 através do banco de dados Economatica.

\subsection{Técnicas utilizadas para a investigação da utilidade de estratégias de investimento baseadas em informações contábeis}

A avaliação do sucesso da estratégia baseada na seleção de uma carteira formada a partir dos sinais financeiros captados nas demonstrações contábeis é feita com base em análises específicas. A primeira delas diz respeito à associação entre o $B r F \_S C O R E$ e o retorno ajustado pelo mercado (para 1 ano e 2 anos após a formação da carteira), controlando-se por diversos outros fatores que possam explicar o comportamento dos retornos futuros. Estes fatores são comumente utilizados na literatura e incluem proxies para o tamanho da empresa, para o risco, para estratégias baseadas em preços passados, entre outras. Adicionalmente, controla-se pelo efeito fixo do setor de cada empresa e de cada ano de análise, considerando-se que pode haver setores, em determinados períodos, que passam por um período de expansão ou recessão e/ou impactos macroeconômicos que afetam todo o conjunto de empresas no período avaliado. Para investigar a relação entre o $B r F \_S C O R E$ e os retornos futuros, estima-se a seguinte equação:

$$
\text { Retorno }=f(x)+u
$$

tal que $E(u / x)=0$ e $E\left(u^{2} / x\right)<\infty$, significando que $E(y / x)=f(x)$. Assim, a estimação de $f(x)$ resulta em um estimador da esperança do retorno, condicional a $x$.

Assim, o retorno futuro é função de uma série de variáveis, dentre as quais se espera que o BrF_SCORE tenha uma relação positiva e significativa para a sua explicação. Para estimar esta relação, utiliza-se, genericamente, o seguinte modelo de regressão:

$$
\mathrm{R}_{i, t+\tau}=\beta_{0}+\beta_{1}\left(B r F_{-} S C O R E_{i, t}\right)+\boldsymbol{\beta} \mathbf{X}_{i, t}+\varepsilon_{i, t}
$$


onde $R_{i, t}$ representa o retorno da ação da empresa $i$ no período $t+\tau, B r F \_S C O R E_{i, t}$ representa a nota recebida pela empresa $i$ no período $t$ com relação a seus indicadores econômico-financeiros e $\mathbf{X}_{i, t}$ representa o vetor de variáveis de controle da empresa $i$ no período $t$.

A partir da equação (16), pode-se expandir a análise para os grupos específicos, ao rodar a regressão, por exemplo, para as empresas com alto PL/P e/ou baixo BCGI. Adicionalmente, utilizam-se análises mais sofisticadas que incluem termos de interação entre as variáveis de interesse.

Para o incremento da robustez dos modelos estimados por pooled ordinary least squares (POLS) utiliza-se a estimação com dados em painel com efeitos fixos. Woodridge (2002) comenta que a estimação com dados em painel com efeitos fixos é utilizada na tentativa de resolver o problema de variáveis não observadas. Supondo que a variável omitida $c_{i}$ seja constante no tempo, haveria o seguinte modelo em painel:

$$
\begin{gathered}
R_{i t}=\beta_{0}+\beta_{1}\left(B r F_{-} S C O R E_{i t}\right)+\mathbf{x}_{i t} \boldsymbol{\beta}+c_{i}+u_{i t}, \quad t=1, \ldots, T \\
E\left(R_{i t} \mid B r F_{-} S C O R E, \mathbf{x}_{i t}, c\right)=\beta_{0}+\beta_{1}\left(B r F_{-} S C O R E_{i t}\right)+\mathbf{x}_{i t} \boldsymbol{\beta}+c_{i} \\
E\left(u_{i t} \mid B r F_{-} S C O R E, \mathbf{x}_{i t}, c\right)=0
\end{gathered}
$$

onde: $c_{\mathrm{i}}$ representa os efeitos não observados em i e $u_{\mathrm{it}}$ são os termos de erro idiossincráticos (pois podem se alterar em i e em $\mathrm{t}$ ).

Tanto os modelos em POLS quanto os estimados com dados em painel e com efeitos fixos são calculados com a matriz robusta de variância-covariância, o que mitiga os efeitos da heteroscedasticidade e da autocorrelação.

Utiliza-se também, para testes posteriores, o modelo Pooled Probit. O modelo Probit considera a probabilidade de determinado evento acontecer, considerando uma função $G$ que é uma função de distribuição cumulativa normal padrão. Pode-se escrever:

$$
P(y=1 \mid x)=G\left(\beta_{0}+\mathbf{x} \boldsymbol{\beta}\right)
$$




$$
\begin{aligned}
& G(z)=\Phi(z) \equiv \int_{\infty}^{z} \phi(v) d v \\
& \text { onde }: \phi(z)=(2 \pi)^{-1 / 2} e^{-z^{2} / 2}
\end{aligned}
$$

A estimação dos coeficientes acima se dá pela aplicação computacional do método da máximaverossimilhança. Este método considera os coeficientes que, com base na amostra, maximizem a soma de $\ell_{i}(\boldsymbol{\beta})=y_{i} \log \left[G\left(x_{i} \boldsymbol{\beta}\right)\right]+\left(1-y_{i}\right) \log \left[1-G\left(x_{i} \boldsymbol{\beta}\right)\right]$, chamada de log-verossimilhança. Para maiores detalhes, consultar Wooldridge (2002).

Finalmente, este trabalho avalia o sucesso de estratégias de investimento baseadas em análise de demonstrações contábeis, por meio da análise dos retornos ajustados pelo mercado obtidos com a carteira de alto $B r F \_S C O R E$ dentre os grupos selecionados e os compara com a carteira de baixo $B r F \_S C O R E$. Esta análise univariada baseia-se no teste de média e de mediana (MWW) e é consistente na medida em que as análises anteriores tenham confirmado que o BrF_SCORE tem associação com os retornos ajustados pelo mercado, mesmo após controlar por outros fatores. Para aumentar a robustez da análise univariada, utiliza-se procedimentos de reamostragem (bootstrap) para confirmar os resultados obtidos nos testes paramétricos.

O teste paramétrico de diferenças de médias é calculado de acordo com a estatística t, dada por:

$$
t=\frac{\bar{X}_{1}-\bar{X}_{2}}{\sqrt{\frac{S_{X 1}^{2}}{n_{1}}+\frac{S_{X 2}^{2}}{n_{2}}}}
$$

onde $\bar{X}_{g}$ é a média da amostra representativa do grupo $g, S_{X g}^{2}$ é a variância da amostra representativa do grupo $g$ e $n_{g}$ é o número de observações no grupo g.

A hipótese nula do teste é a não diferença entre as médias dos grupos avaliados, enquanto a hipótese alternativa é de que existe diferença entre as médias dos grupos. Neste contexto, avaliase se um determinado grupo (por exemplo, o grupo de empresas com alto BrF_SCORE) possui a média dos retornos maior do que o outro grupo em análise (por exemplo, o grupo de empresas com baixo BrF_SCORE). Para a rejeição da hipótese nula, a estatística $t$ deve ser um número menor que $-t$ crítico ou maior que $+t$ crítico para um dado nível de confiança. 
Adicionalmente ao teste paramétrico de médias, considera-se uma versão não paramétrica para teste de medianas conhecida por teste de Wilcoxson (para duas amostras de mesmo tamanho) ou Mann-Whitney (amostras de tamanhos diferentes). Siegel (1956) mostra que o teste de MannWhitney/Wilcoxson (MWW) considera a soma dos postos das variáveis, supondo que postos altos, médios e baixos devem-se distribuir-se equilibradamente entre as duas amostras em análise. O MWW testa a hipótese de que duas amostras independentes são de populações com a mesma distribuição. Se a hipótese nula é verdadeira, espera-se que os postos repartam igualmente as amostras e que a soma dos postos em cada um dos grupos seja aproximadamente igual. Se isso ocorre, espera-se que a mediana seja a mesma. O procedimento do teste de MWW para duas amostras é o seguinte:

1 - Ordene as variáveis em análise por ordem crescente de valor e atribua um posto a cada uma delas (1 para a menor e $N$ para a maior, onde $N$ é o número total de variáveis); 2 - Calcule a some soma dos postos (amostra 1 e amostra 2), ou seja, calcule $N(N+1) / 2$.

4 - Calcule os valores esperados dos postos da amostra 1 ponderando pelo número de observações nesta amostra $\left(n_{1}\right)$, como $E\left(G r_{1}\right)=n_{1} / N[N(N+1) / 2]$. Para amostra 2 calcule $E\left(G r_{2}\right)=n_{2} / N[N(N+1) / 2]$.

5 - Para amostras grandes $(\mathrm{N}>30)$, supõe-se $z=\frac{G r_{k}-E\left(G r_{k}\right)}{\sigma_{u}}$, onde $\sigma_{u}=\sqrt{\frac{n_{1} n_{2}\left(n_{1}+n_{2}+1\right)}{12}}$ e $\mathrm{G} r_{k}$ é a soma dos postos da amostra $\mathrm{k}$.

6 - Compara-se o valor obtido em z, com o valor crítico do teste MWW para um dado nível de significância.

Adicionalmente, utiliza-se o procedimento bootstrap para dar maior robustez aos resultados obtidos. O bootstrap é um método estatístico para se estimar a distribuição empírica amostral de um estimador ao realizar um procedimento computacional de reamostragem com reposição da amostra original. O procedimento básico do bootstrap é:

1 - Sorteia-se aleatoriamente e com reposição $n$ observações da amostra original, onde $n$ é o tamanho da amostra;

2 - Calcula-se a estatística desejada para a amostra obtida no passo 1;

3 - Repete-se os passos 1 e 2 muitas vezes (por exemplo, 1.000 vezes);

4 - Utiliza-se a distribuição empírica amostral da estatística como uma aproximação da verdadeira distribuição populacional; 
5 - Realiza-se o teste de hipóteses.

A próxima seção apresenta a amostra, as especificações dos testes utilizados e discute os resultados obtidos para a investigação da utilidade das estratégias de investimento baseadas em demonstrações contábeis. 


\section{RESULTADOS E ANÁLISES}

Com o objetivo investigar o problema de pesquisa e de ratificar ou refutar as hipóteses levantadas, esta seção apresenta o processo de seleção da amostra, as estatísticas descritivas dos dados e os resultados obtidos nos testes empíricos. Para cada uma das hipóteses levantadas apresentam-se os testes utilizados e os resultados obtidos.

\subsection{Seleção da amostra e Estatística Descritiva}

A amostra foi selecionada a partir de todas as empresas que não fazem parte do setor financeiro ou de seguros listadas na Bovespa durante o período de 1997 a 2007. Os dados relativos às demonstrações contábeis foram coletados a partir da base de dados da Economatica e compreendem o período de janeiro de 1997 a dezembro de 2004. Os dados relativos ao retorno ajustado pelo mercado 1 ano e 2 anos à frente foram coletados para o período de 1997 a 2007. Isto porque os retornos são avaliados nos anos posteriores à formação da carteira com base na estratégia de investimentos. Adicionalmente, os dados relativos à governança corporativa são representados pelo BCGI e estão disponíveis para os anos de 1998, 2000, 2002 e 2004.

Nesse contexto foram selecionadas as ações mais líquidas de cada empresa e houve a exclusão de empresas onde não havia informações sobre preço da ação ou sobre o patrimônio líquido. Calculou-se o índice PL/P como a divisão do valor do patrimônio líquido da empresa pelo seu respectivo valor de mercado (Mkt. Cap.) ao final de cada exercício (ano). O valor de mercado (Mkt. Cap.) é definido pelo preço da ação multiplicado pelo número de ações da empresa. Também houve a exclusão de empresas com valor de mercado negativo e com índice PL/P negativo e de empresas sem retorno (negociação) para 1 ou 2 anos. Este procedimento viabiliza a aplicação prática da estratégia. Finalmente, houve o corte de $1 \%$ dos maiores e $1 \%$ menores retornos (22 observações para cima e para baixo ${ }^{49}$. As empresas com dados suficientes são classificadas anualmente e são identificadas as distribuições empíricas do índice PL/P, do Mkt. Cap. ${ }^{50}$ e do BCGI. Estes procedimentos resultaram em uma amostra de 1.555 observações para o período em análise.

\footnotetext{
49 Estatísticamente este processo é utilizado para aumentar a robustez da análise ao excluir possíveis valores extremos. Este método é conhecido por trimmed data at $1 \%$.

${ }^{50}$ Deve-se reconhecer que o Mkt. Cap. deve ser utilizado com cautela em algumas situações onde a liquidez das ações é baixa. Nesse sentido, este trabalho controla diretamente pelo fator liquidez nas análises realizadas.
} 
Utiliza-se a distribuição do PL/P do ano anterior ao da construção da carteira de investimentos e classificam-se as empresas por quintis de $\mathrm{PL} / \mathrm{P}^{51}$. Procedimentos similares são utilizados para classificar as empresas por quintis de BCGI. Para representar as empresas de maior índice PL/P seleciona-se aquelas pertencentes ao quintil superior, e para selecionar empresas com arranjos fracos de governança, selecionam-se as empresas classificadas no quintil inferior.

Algumas variáveis importantes com relação aos controles a serem utilizados são: (i) a liquidez das ações (LIQUIDEZ_AÇÃO), calculada como $100 \times(p \times P) \times \sqrt{(n \times N / v \times V)}$, onde p é o número de dias em que houve pelo menos um negócio com a ação dentro do período escolhido, $\mathrm{P}$ é número total de dias do período escolhido, n é o número negócios com a ação dentro do período escolhido, $\mathrm{N}$ é o numero de negócios com todas as ações dentro do período escolhido, v é o volume em dinheiro com a ação dentro do período escolhido e V é o volume em dinheiro com todas as ações dentro do período escolhido, (ii) o índice de endividamento de curto prazo (DÍVIDA_CP), calculada pela divisão da dívida de curto prazo pelo endividamento de longo prazo no final do ano, (iii) a estrutura de capital da empresa (ESTRUT_CAP), definida como a divisão do endividamento total da empresa pelo total de recursos obtidos (capital próprio e capital de terceiros) no final do ano e (iv) o índice preço-lucro $(P / L)$, calculado pela divisão do preço da ação pelo lucro do período.

A Tabela 3 apresenta o resultado das estatísticas descritivas das variáveis-base da amostra em estudo. O painel A da Tabela 3 mostra uma grande heterogeneidade das empresas na amostra. $\mathrm{O}$ ativo total médio das empresas é de $\mathrm{R} \$ 3,8$ bilhões, enquanto o valor de mercado médio das empresas é de R \$ 1,7 bilhão. Quando se considera a mediana destas variáveis, que são menos sensíveis a distribuições muito dispersas, percebe-se que os valores decrescem consideravelmente. A mediana do ativo total das empresas é de R \$ 872 milhões, enquanto a mediana do valor de mercado é de $\mathrm{R} \$ 221$ milhões. Isto significa que há empresas no quintil superior que alteram a média em relação aos valores de outras empresas. Isto pode ser percebido ao se avaliar o máximo valor de mercado e o máximo valor do ativo obtido na amostra. No contexto apresentado, percebe-se que os dados econômico-financeiros padronizados são melhores para as comparações realizadas no estudo. Assim, todas as variáveis apresentadas na Tabela 3,

${ }^{51}$ Veja item 4.2 para maiores detalhes. 
com exceção de $M k t$. Cap e do ATIVO, são apresentadas com alguma padronização em relação às características da empresa.

A Tabela 3, painel A mostra que a média (mediana) do índice PL/P no Brasil é de 2,92 (1,45). Estes resultados são consideravelmente diferentes dos encontrados por Mohanran (2005, p.142) no mercado norte-americano, onde a média (mediana) do PL/P para todas as empresas é de 0,82 $(0,61)$. Estas diferenças demonstram que no período analisado, as empresas brasileiras foram negociadas, em média, por um valor menor do que o valor contábil do seu patrimônio, o que difere do encontrado em um mercado desenvolvido como o norte americano. O painel B da Tabela 3 mostra que a correlação entre o índice PL/P e o BCGI é negativa, e não significante a $5 \%$, o que demonstra que a associação inversa entre empresas com boa governança e alto índice PL/P não é tão clara. Adicionalmente, percebe-se que a média do índice PL/P para as empresas classificadas no quintil inferior de BCGI (governança fraca) é de 2,97, contra 9,35 para as empresas no quintil superior do índice PL/P. Assim, a análise inicial aponta que as características com relação ao índice PL/P das empresas com baixo BCGI são diferentes daquelas classificadas como alto PL/P, demonstrando a coerência na análise separada destes grupos.

Outros pontos são interessantes de serem destacados na Tabela 3. O painel A mostra que a média (mediana) do BCGI das empresas brasileiras é de 0,336 (0,333), o que representa um baixo nível considerando-se o intervalo desta variável [0;1]. A nota máxima foi de 0,80 , o que demonstra haver considerável espaço para a melhoria das empresas brasileiras com relação à governança. A Tabela 3, painel B, mostra que as variáveis mais correlacionadas com o BCGI são o Mkt. Cap., o valor do ativo da empresa, a liquidez de suas ações e a estrutura de capital. A análise dos dados sugere que empresas maiores, com ações mais líquidas no mercado e que utilizam mais financiamento externo (dívida) tendem a ter um maior nível de governança. Percebe-se que há poucas empresas com níveis altos de liquidez das ações, enquanto a maioria se encontra muito abaixo da média. Isto ocorre, pois algumas empresas têm a liquidez relativa muito alta quando comparadas com as demais. A média (mediana) da variável LIQUIDEZ_AÇÃO é de 0,279 $(0,007)$, enquanto seu valor máximo é de 10,97 . As empresas que têm o índice de liquidez da ação acima de 0,11 estão no quartil superior da amostra, demonstrando que poucas empresas são muito negociadas, enquanto a maioria tem um índice mais modesto. O painel B da Tabela 3 evidencia que o índice de liquidez das ações tem uma correlação pequena, mas negativa, com o índice PL/P, indicando que empresas mais líquidas têm maior valor de mercado em relação ao patrimônio líquido do que empresas menos líquidas. 
Tabela 3. Estatística descritiva

\begin{tabular}{|c|c|c|c|c|c|c|c|c|}
\hline \multicolumn{9}{|c|}{ Estatística Descritiva dos índices financeiros e de governança das Empresas } \\
\hline \multicolumn{9}{|c|}{ (Observações empresas-ano entre 1997 e 2004) } \\
\hline \multicolumn{9}{|c|}{ Painel A } \\
\hline & & Desvio & & & & & & \\
\hline Variável & Média & Padrão & Mín. & Q1 & Mediana & Q3 & Máx. & $\mathrm{n}$ \\
\hline$\overline{P L / P}$ & 2,9239 & 8,8204 & 0,0073 & 0,7774 & 1,4453 & 2,6660 & 254,11 & 1555 \\
\hline Mkt. Cap. $(R \$$ mil $)$ & 1.685 .531 & 5.961 .239 & 264 & 43.164 & 221.313 & 844.272 & 107.000 .000 & 1555 \\
\hline$A T I V O(R \$$ mil $)$ & 3.771 .567 & 12.300 .000 & 8.945 & 258.625 & 872.081 & 2.507 .458 & 147.000 .000 & 1555 \\
\hline$B C G I$ & 0,3357 & 0,1533 & 0,0000 & 0,2667 & 0,3333 & 0,4667 & 0,8000 & 1543 \\
\hline LIQUIDEZ_AÇÃ $O$ & 0,2787 & 0,9329 & 0,0000 & 0,0003 & 0,0078 & 0,1092 & 10,9666 & 1555 \\
\hline DÍVIDA_CP & 0,5064 & 0,2835 & 0,0000 & 0,2790 & 0,4691 & 0,7151 & 1,0000 & 1488 \\
\hline$E S T R U T \_C A P$ & 0,5776 & 0,2154 & 0,0000 & 0,4216 & 0,5820 & 0,7434 & 0,9988 & 1555 \\
\hline$P / L$ & 8,1140 & 80,2196 & $-731,95$ & $-0,3100$ & 5,0200 & 10,4200 & 2210,55 & 1472 \\
\hline$R O A$ & 0,0285 & 0,1085 & $-1,2664$ & $-0,0076$ & 0,0278 & 0,0732 & 0,6996 & 1512 \\
\hline$F L C$ & 0,0146 & 0,1186 & $-0,9132$ & $-0,0136$ & 0,0021 & 0,0303 & 2,2320 & 1512 \\
\hline$\triangle R O A$ & 0,0086 & 0,1065 & $-0,7369$ & $-0,0285$ & 0,0038 & 0,0379 & 0,8952 & 1445 \\
\hline ACCRUAL & $-0,0289$ & 0,1267 & $-0,8765$ & $-0,0808$ & $-0,0316$ & 0,0151 & 1,8494 & 1418 \\
\hline$\triangle L I Q U I D$ & $-0,1241$ & 4,6846 & $-125,10$ & $-0,1900$ & 0,0100 & 0,2600 & 56,2100 & 1555 \\
\hline$\triangle A L A V$ & 0,0073 & 0,1016 & $-0,6383$ & $-0,0303$ & 0,0027 & 0,0493 & 0,8134 & 1555 \\
\hline$\triangle G I R O$ & 0,0413 & 0,2194 & $-1,5015$ & $-0,0313$ & 0,0219 & 0,1031 & 1,9087 & 1555 \\
\hline$\triangle M A R G E M$ & 0,0135 & 0,1430 & $-1,0611$ & $-0,0247$ & 0,0036 & 0,0401 & 1,0476 & 1555 \\
\hline \multicolumn{9}{|c|}{$\begin{array}{l}\text { Painel B } \\
\end{array}$} \\
\hline & \multicolumn{2}{|c|}{ Correlação com o BCGI } & \multicolumn{2}{|c|}{ Correlação com o PL/P } & \multicolumn{2}{|c|}{ Empresas Baixo BCGI } & \multicolumn{2}{|c|}{ Empresas Alto PL/P } \\
\hline & & & & & & Desvio & & Desvio \\
\hline & Correlação & $p$ valor & Correlação & $p$ valor & Média & Padrão & Média & Padrão \\
\hline$P L / P$ & $-0,0464$ & 0,0682 & 1,0000 & NA & 2,9666 & 4,1478 & 9,3530 & 18,4454 \\
\hline Mkt. Cap. $(R \$$ mil $)$ & 0,1997 & 0,0000 & $-0,0655$ & 0,0098 & 534.484 & 1.538 .901 & 378.980 & 2.370 .589 \\
\hline$A T I V O(R \$ \mathrm{mil})$ & 0,1720 & 0,0000 & $-0,0420$ & 0,1000 & 2.207 .561 & 9.897 .958 & 2.602 .021 & 14.100 .000 \\
\hline$B C G I$ & 1,0000 & NA & $-0,0464$ & 0,0682 & 0,1244 & 0,0954 & 0,3086 & 0,1322 \\
\hline LIQUIDEZ_AÇÃ $O$ & 0,1874 & 0,0000 & $-0,0592$ & 0,0196 & 0,0861 & 0,3230 & 0,0840 & 0,4365 \\
\hline DÍVIDA_CP & $-0,0250$ & 0,3255 & $-0,0926$ & 0,0003 & 0,5512 & 0,2942 & 0,5651 & 0,3088 \\
\hline$E S T R U T \_C A P$ & 0,0515 & 0,0489 & $-0,0190$ & 0,4662 & 0,6138 & 0,2279 & 0,5453 & 0,2259 \\
\hline$P / L$ & 0,0256 & 0,3217 & $-0,0875$ & 0,0007 & 3,7942 & 35,6058 & 4,2377 & 35,8475 \\
\hline$R O A$ & 0,0197 & 0,4453 & $-0,0211$ & 0,4116 & 0,0230 & 0,0940 & $-0,0049$ & 0,0798 \\
\hline$F L C$ & 0,0057 & 0,8293 & $-0,0147$ & 0,5757 & 0,0079 & 0,0688 & 0,0058 & 0,1473 \\
\hline$\triangle R O A$ & 0,0144 & 0,5890 & 0,0038 & 0,8876 & 0,0066 & 0,1019 & 0,0111 & 0,1150 \\
\hline$A C C R U A L$ & 0,0187 & 0,4620 & $-0,0127$ & 0,6181 & $-0,0304$ & 0,1127 & $-0,0269$ & 0,0930 \\
\hline$\triangle L I Q U I D$ & $-0,0170$ & 0,5057 & 0,0140 & 0,5822 & $-0,0306$ & 1,2543 & $-0,7626$ & 10,1999 \\
\hline$\triangle A L A V$ & 0,0255 & 0,3167 & $-0,0305$ & 0,2292 & 0,0043 & 0,0997 & $-0,0004$ & 0,0966 \\
\hline$\triangle G I R O$ & 0,0214 & 0,4001 & 0,0202 & 0,4250 & 0,0408 & 0,2263 & 0,0169 & 0,1911 \\
\hline$\triangle M A R G E M$ & $-0,1090$ & 0,0000 & 0,0271 & 0,2962 & $-0,0027$ & 0,1615 & 0,0148 & 0,1598 \\
\hline
\end{tabular}

PL/P - índice PL/P, calculado pela divisão do patrimônio líquido da empresa no final do exercício por seu Mkt. Cap. na mesma data correspondente.

Mkt. Cap. $(R \$$ mil $)$ - preço da ação no final do ano multiplicado pelo número de ações da empresa no mesmo período.

ATIVO $(R \$$ mil $)$ - ativo total da empresa no final do ano.

$B C G I$ - nota do índice de governança no ano em análise. Varia de 0 a 1.

LIQUIDEZ_AÇÃO - índice representativo da liquidez das ações na Bovespa. Quanto maior o valor, mais líquida a ação. Calculado pela seguinte fórmula: $100(p . P) \sqrt{ }(n . N / v . V)$, onde p é o número de dias em que houve pelo menos um negócio com a ação dentro do período escolhido, P é número total de dias do período escolhido, n é o número negócios com a ação dentro do período escolhido, $\mathrm{N}$ é o numero de negócios com todas as ações dentro do período escolhido, v é o volume em dinheiro com a ação dentro do período escolhido e V é o volume em dinheiro com todas as ações dentro do período escolhido.

DÍVIDA_CP - dívida de curto prazo dividida pelo endividamento de longo prazo no final do ano.

ESTRUT_CAP - relação entre o endividamento total da empresa e o total de recursos (capital próprio e capital de terceiros) no final do ano.

$P / L$ - índice preço-lucro. Calculado pela divisão do preço da ação pelo lucro do período.

$R O A$ - retorno sobre o ativo, calculado como lucro líquido dividido pelo ativo total da empresa no início do exercício.

FLC - fluxo líquido de caixa, definido como a alteração na posição de caixa e equivalentes de caixa da empresa dividida pelo ativo total no início do exercício.

. $\triangle R O A$ - variação do retorno sobre o ativo, calculada como o $R O A$ do exercício subtraída do $R O A$ do exercício anterior.

ACCRUAL - representa as variações nos ativos circulantes (com exceção dos itens classificados como caixa e equivalentes) menos as variações nos passivos circulantes (com exceção das dívidas de curto prazo) subtraídos da depreciação do período. Este valor é padronizado pelo ativo total do início do exercício.

$\triangle L I Q U I D$ - variação no índice de liquidez corrente da empresa em relação ao índice do ano anterior. O índice de liquidez corrente é calculado pela divisão do ativo circulante pelo passivo circulante da empresa no final do período.

. $\triangle A L A V A V$ - variação no índice de endividamento total em relação ao ativo total no início do exercício.

. $\triangle G I R O$ - mudança no índice de giro da empresa do período atual em relação ao período anterior. O índice de giro é calculado pela divisão da receita líquida da empresa no exercício pelos seus ativos totais no início do período.

. $\triangle M A R G E M$ - variação na margem bruta da empresa no exercício em relação à margem do período anterior. A margem bruta é calculada pela divisão do lucro bruto da empresa pelo valor das vendas da empresa. 
Com relação às variáveis econômico-financeiras, vale ressaltar que a média (mediana) do $R O A$ das empresas da amostra é de 2,85\% (2,78\%), enquanto a média do ROA das empresas com alto índice PL/P é $-0,49 \%$, demonstrando uma pior performance operacional das empresas classificadas neste grupo. Em contrapartida, a Tabela 3, painel B também mostra que as empresas classificadas no grupo de baixa governança corporativa têm a média do ROA de 2,30\%. Contudo as variações do ROA ( $\triangle R O A)$ e da margem ( $\triangle M A R G E M)$ aparentemente são maiores no grupo das empresas classificadas como alto PL/P em relação às empresas com baixo BCGI, o que indica a possibilidade daquelas empresas identificarem a necessidade de recuperação nos seus índices de rentabilidade. Outro ponto que chama a atenção na Tabela 3, painel A são os altos valores do desvio padrão das variáveis $P / L$ (índice preço-lucro) e $\Delta L I Q U I D$. Estas variações podem ser explicadas, no caso da variável $P / L$, pelas grandes oscilações dos preços de mercado para empresas com lucros correntes baixos, enquanto no caso de $\triangle L I Q U I D$ percebe-se pequenas aparições de números bastante negativos (o mínimo é de -125,1, enquanto o valor referente ao primeiro quartil é de -0,19). Nestas situações, a mediana é uma medida mais adequada por ser robusta a valores extremos. Conforme apresentado no painel A da Tabela 3, a mediana do $P / L$ é de 5,02 e da $\triangle L I Q U I D$ é de 0,01 .

Vale salientar que o resultado obtido no cálculo do índice agregado dos sinais financeiros, o BrF_SCORE, é menos sensível à valores extremos que podem não representar a realidade econômico-financeira da empresa, pois ele atribui notas específicas (0 ou 1) para cada item em análise. Adicionalmente, vale lembrar a característica corretiva das partidas dobradas que servem como base para a elaboração das demonstrações contábeis. Assim, valores extremos em um determinado ano que sejam oriundos de alterações de políticas contábeis, serão contrabalanceados no futuro quando houver a realização do evento. A seguir discute-se a associação do BrF_SCORE com os retornos das ações.

\subsection{Associação entre o BrF_SCORE e os retornos futuros}

A utilidade da estratégia de investimento baseada em demonstrações contábeis pode ser inicialmente avaliada pela análise de correlação existente entre os sinais financeiros componentes do índice agregado (BrF_SCORE) com os retornos futuros das ações. Esta análise é realizada na Tabela 4 onde são apresentadas as correlações de Spearman entre as cada um dos indicadores individuais do BrF_SCORE e os retornos de 1 e 2 anos ajustados pela carteira de mercado. 
Adicionalmente, a análise é expandida para os grupos de empresas com baixo BCGI e para o grupo de empresas com alto PL/P. De acordo com a argumentação apresentada na fundamentação teórica deste trabalho (capítulo 2), espera-se que correlação entre o BrF_SCORE e os retornos seja maior para estes grupos do que para o conjunto total de empresas.

A Tabela 4, painel A, apresenta a correlação entre os sinais financeiros, o BrF_SCORE e os retornos (1 e 2 anos à frente) ajustados pelo mercado. Percebe-se que as variáveis individuais que apresentam maior correlação com os retornos de 1 ano (2 anos) à frente são o $F_{-} R O A$ e o $F_{-}$ $\triangle M A R G E M$, com valores de respectivamente $0,706(0,731)$ e de $0,0792(0,119)$. Interessante notar que a única variável que apresenta correlação com sinal negativo com os retornos à frente nos dois anos em análise é o $F \_A C C R U A L$. Este ponto deve ser explorado mais profundamente, mas aparentemente a "anomalia dos accruals", detectada por Sloan (1996) no mercado norte americano, pode não ser significativa no mercado brasileiro. Esta argumentação encontra suporte em Pincus et al (2007) que demonstram que a "anomalia dos accruals" está presente mais consistentemente em países de direito consuetudinário (common law), notadamente na Austrália, Canadá, no Reino Unido e nos Estados Unidos. Vale ressaltar que a correlação do BrF_SCORE com o RET_AJ é maior do que qualquer correlação individual dos sinais financeiros, indicando que este é um bom índice composto para se avaliar o desempenho futuro da empresa.

Os painéis B e C da Tabela 4 apresentam a correlação de Spearman entre as variáveis nos dois subgrupos de interesse desta pesquisa. Interessante notar que a correlação entre o $B r F \_S C O R E$ e os retornos (RET_AJ e RET2_AJ) continua sendo maior, para os dois grupos de empresas (alto PL/P e baixo BCGI), do que a correlação individual de cada sinal. Além disso, percebe-se que a correlação do BrF_SCORE com os retornos futuros é maior tanto para o grupo de empresas com baixa governança quanto para o grupo de empresas com alto estresse financeiro com relação à amostra total do estudo. Estas evidências dão suporte a uma investigação mais profunda sobre a relação do BrF_SCORE e os retornos futuros das ações nos grupos em análise. 
Tabela 4. Correlação de Spearman entre os componentes do BrF_SCORE e os retornos de 1 ano e 2 anos à frente ajustados pelo mercado

Painel A: Correlação de Sperman para todas as variáveis na amostra

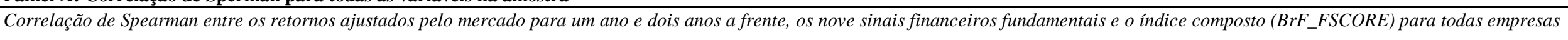
na amostra

\begin{tabular}{|c|c|c|c|c|c|c|c|c|c|c|c|c|}
\hline & RET_AJ & $R E T 2 \_A J$ & $F_{-} R O A$ & $F_{-} \triangle R O A$ & $F_{-} \triangle M A R G E M$ & $F_{-} F L C$ & $F_{-} \triangle L I Q U I D$ & $F_{-} \triangle A L A V$ & $F_{-} \Delta G I R O$ & $F \_A C C R U A L$ & $O F \_P U B$ & BrF_SCORE \\
\hline$\overline{R E T \_A J}$ & 1,0000 & & & & & & & & & & & \\
\hline$R E T 2 \_A J$ & 0,6520 & 1,0000 & & & & & & & & & & \\
\hline$F_{-} R O A$ & 0,0760 & 0,0731 & 1,0000 & & & & & & & & & \\
\hline$F_{-} \triangle R O A$ & 0,0391 & 0,0332 & 0,3394 & 1,0000 & & & & & & & & \\
\hline$F_{-} \triangle M A R G E M$ & 0,0702 & 0,1192 & 0,0460 & 0,1936 & 1,0000 & & & & & & & \\
\hline$F_{-} F L C$ & 0,0489 & 0,0469 & 0,1293 & 0,1229 & 0,0369 & 1,0000 & & & & & & \\
\hline$F_{-} \Delta L I Q U I D$ & 0,0445 & 0,0319 & 0,0742 & 0,0868 & 0,0727 & 0,1619 & 1,0000 & & & & & \\
\hline$F_{-} \triangle A L A V$ & 0,0401 & 0,0189 & 0,1836 & 0,2157 & 0,0569 & $-0,0051$ & 0,1410 & 1,0000 & & & & \\
\hline$F_{-} \Delta G I R O$ & 0,0157 & 0,0453 & $-0,0359$ & 0,0947 & 0,1051 & $-0,0121$ & 0,1296 & 0,0857 & 1,0000 & & & \\
\hline$F \_A C C R U A L$ & $-0,0264$ & $-0,0264$ & $-0,0318$ & $-0,0019$ & $-0,0092$ & 0,1732 & $-0,1928$ & 0,1156 & 0,0269 & 1,0000 & & \\
\hline$O F \_P U B$ & $-0,0065$ & 0,0036 & $-0,0642$ & $-0,0113$ & 0,0135 & $-0,0054$ & 0,0043 & $-0,0020$ & $-0,0568$ & $-0,0186$ & 1,0000 & \\
\hline BrF_SCORE & 0,0897 & 0,0981 & 0,4602 & 0,5830 & 0,4218 & 0,4499 & 0,4121 & 0,5075 & 0,3774 & 0,2894 & 0,0524 & 1,0000 \\
\hline
\end{tabular}

Correlação de Spearman entre os retornos ajustados pelo mercado para um ano e dois anos a frente, os nove sinais financeiros fundamentais e o índice composto (BrF_FSCORE) para as empresas de alto PL/P

\begin{tabular}{|c|c|c|c|c|c|c|c|c|c|c|c|c|}
\hline & RET_AJ & RET2_AJ & $\overline{F \_R O A}$ & $F_{-} \triangle R O A$ & $\bar{~} F_{-} \triangle M A R G E M$ & 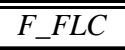 & $\bar{F}_{F_{-} \Delta L I Q U I D}$ & 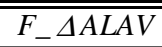 & 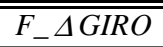 & F_F_ACCRUAL & $\overline{O O F \_P U B}$ & 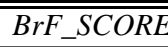 \\
\hline$\overline{R E T \_A J}$ & 1,0000 & & & & & & & & & & & \\
\hline$R E T 2 \_A J$ & 0,5970 & 1,0000 & & & & & & & & & & \\
\hline$F_{-} R O A$ & 0,0134 & 0,0626 & 1,0000 & & & & & & & & & \\
\hline$F_{-} \Delta R O A$ & $-0,0194$ & $-0,0419$ & 0,3406 & 1,0000 & & & & & & & & \\
\hline$F_{-} \triangle M A R G E M$ & 0,1048 & 0,1995 & 0,0356 & 0,1342 & 1,0000 & & & & & & & \\
\hline$F \_F L C$ & 0,0814 & 0,0978 & 0,1115 & 0,0745 & $-0,0460$ & 1,0000 & & & & & & \\
\hline$F_{-} \Delta L I Q U I D$ & 0,0588 & 0,0885 & 0,1226 & 0,1137 & 0,0710 & 0,0983 & 1,0000 & & & & & \\
\hline$F_{-} \triangle A L A V$ & 0,1145 & 0,0997 & 0,1789 & 0,1475 & 0,0983 & $-0,0975$ & 0,0717 & 1,0000 & & & & \\
\hline$F_{-} \Delta G I R O$ & 0,1151 & 0,1980 & 0,0526 & 0,1356 & 0,0961 & 0,0630 & 0,1139 & 0,0422 & 1,0000 & & & \\
\hline$F \_A C C R U A L$ & $-0,0429$ & $-0,0297$ & $-0,0792$ & $-0,0751$ & $-0,0307$ & 0,1564 & $-0,2674$ & 0,0334 & 0,0325 & 1,0000 & & \\
\hline$\overline{O F} \_P U B$ & $-0,0123$ & 0,0247 & $-0,0188$ & $-0,0341$ & 0,1043 & 0,0270 & 0,0283 & 0,1057 & $-0,0886$ & $-0,0753$ & 1,0000 & \\
\hline$\underline{B r} \bar{F} \_S C O R E$ & 0,1266 & 0,2021 & 0,5228 & 0,5598 & 0,3989 & 0,3981 & 0,3886 & 0,4337 & 0,4455 & 0,1972 & 0,0662 & 1,0000 \\
\hline
\end{tabular}


Tabela 4 - Continuação

Painel C: Correlação de Sperman para as empresas com baixo BCGI

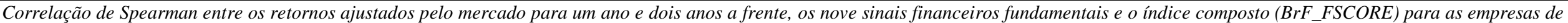
baixo BCGI

\begin{tabular}{|c|c|c|c|c|c|c|c|c|c|c|c|c|}
\hline & "RET_AJ & RET2_AJ & 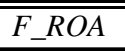 & $\overline{F_{-} \Delta R O A}$ & 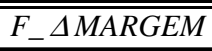 & 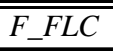 & $\overline{F_{-} \Delta L I Q U I D}$ & 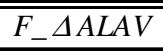 & 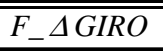 & IF_ACCRUAL & OF_PUB & 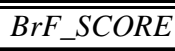 \\
\hline$\overline{R E T \_A J}$ & 1,0000 & & & & & & & & & & & \\
\hline$R E T 2 \_A J$ & 0,6257 & 1,0000 & & & & & & & & & & \\
\hline$F_{-} R O A$ & 0,1025 & 0,1073 & 1,0000 & & & & & & & & & \\
\hline$F_{-} \triangle R O A$ & 0,0999 & 0,0535 & 0,3306 & 1,0000 & & & & & & & & \\
\hline$F_{-} \triangle M A R G E M$ & 0,0975 & 0,1114 & $-0,0083$ & 0,1701 & 1,0000 & & & & & & & \\
\hline$F_{-} F L C$ & 0,0603 & 0,1025 & 0,0508 & 0,0461 & $-0,0051$ & 1,0000 & & & & & & \\
\hline$F_{-} \triangle L I Q U I D$ & 0,0968 & 0,1077 & 0,0722 & 0,0599 & 0,0738 & 0,1626 & 1,0000 & & & & & \\
\hline$F_{-} \triangle A L A V$ & 0,1187 & 0,0754 & 0,2679 & 0,2117 & 0,0461 & 0,0685 & 0,1676 & 1,0000 & & & & \\
\hline$F_{-} \Delta G I R O$ & 0,1682 & 0,1194 & $-0,0032$ & 0,1430 & 0,0838 & 0,0734 & 0,0880 & 0,0223 & 1,0000 & & & \\
\hline$F \_A C C R U A L$ & $-0,0250$ & $-0,0243$ & $-0,0402$ & $-0,0283$ & $-0,0271$ & 0,1914 & $-0,1599$ & 0,1281 & 0,0521 & 1,0000 & & \\
\hline$\overline{O F} \_P U B$ & $-0,0249$ & 0,0461 & $-0,0303$ & 0,0688 & 0,1137 & 0,0255 & 0,0582 & 0,1211 & $-0,0550$ & 0,0050 & 1,0000 & \\
\hline BrF_SCORE & 0,2113 & 0,1869 & 0,4521 & 0,5512 & 0,3705 & 0,4389 & 0,4083 & 0,5482 & 0,3968 & 0,3044 & 0,1510 & 1,0000 \\
\hline
\end{tabular}

$R E T \_A J$ é calculado como o retorno de uma carteira buy-and-hold para o período de 1 ano a partir de 01 de maio do ano de formação da carteira menos o retorno da carteira de mercado para o mesmo período em análise.

RET2_AJ é calculado como o retorno de uma carteira buy-and-hold para o período de 2 anos a partir de 01 de maio do ano de formação da carteira menos o retorno da carteira de mercado para o mesmo período em análise.

$F_{-} R O A=1$ se $R O A$ é positivo; 0 caso contrário. O ROA é definido como o lucro líquido dividido pelo ativo total da empresa no início do exercício.

$F_{-} \triangle R O A=1$ se $\triangle R O A$ é positivo; 0 caso contrário.

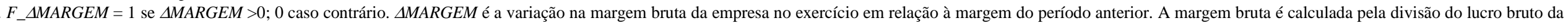
empresa pelo valor das vendas da empresa.

$F F C L=1$ se $F C L$ positivo; 0 caso contrário. $F L C$ é definido como a alteração na posição de caixa e equivalentes de caixa da empresa (fluxo líquido de caixa), padronizada pelo ativo total no início do exercício.

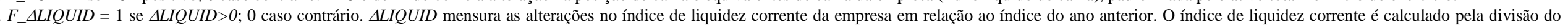
ativo circulante pelo passivo circulante da empresa no final do período.

$F_{-} \triangle A L A V=1$ se $\triangle A L A V<0 ; 0$ caso contrário. $\triangle A L A V$ representa as variações no índice de endividamento total em relação ao ativo total no início do exercício.

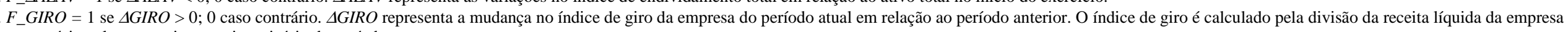
no exercício pelos seus ativos totais no início do período.

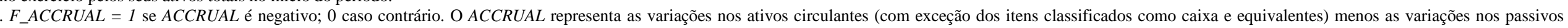
circulantes (com exceção das dívidas de curto prazo) subtraídos da depreciação do período. Este valor é padronizado pelo ativo total do início do exercício.

$O F_{-} P U B=1$ se a empresa não realizou emissões de ações no ano; 0 caso contrário.

BrF $S C O R E=F_{-} R O A+F \_F C L+F \_\Delta R O A+F_{-} A C C R U A L+F_{-} \Delta L I Q U I D+F_{-} \triangle A L A V+P F_{-} P U B+F_{-} \Delta M A R G E M+F_{-} \Delta G I R O$ 
A Tabela 5 apresenta as resultados da regressão do retorno ajustado pelo mercado 1 ano à frente $\left(R E T \_A J\right)$ e do retorno ajustado pelo mercado 2 anos à frente (RET2_AJ) com o BrF_SCORE, controlando por outros fatores que, de acordo com a teoria, poderiam explicar o desempenho dos retornos observados e poderiam estar correlacionadas com o BrF_SCORE. Algumas das características das ações que podem explicar as diferenças nos retornos realizados são o tamanho da empresa, que pode ter como proxy seu valor de mercado ou o valor dos ativos da empresa, o índice PL/P, que é utilizado como proxy de risco e variáveis de estratégias de momento, que se baseiam em retornos passados (PIOTROSKI, 2000; GOMPERS et al, 2003; MOHANRAN, 2005). Este trabalho, também considera a liquidez das ações como elemento importante para a viabilização das estratégias. Este fator também é introduzido nas regressões de maneira a avaliar seu impacto. Adicionalmente, controla-se pelo setor econômico de cada empresa, pois em determinados períodos a expansão/contração do setor pode explicar de forma relevante parte da variação dos retornos futuros da ação, e pelos anos de análise, para se controlar por possíveis efeitos macroeconômicos que possam influenciar as empresas e o mercado de capitais.

O painel A da Tabela 5 analisa a relação entre o BrF_SCORE e o RET_AJ para todas as empresas na amostra e para os grupos de alto índice PL/P (20\% maiores índices), alta governança (20\% maiores índices), baixo índice PL/P (20\% menores índices) e baixa governança (20\% menores índices). Esta partição é realizada para a avaliação das hipóteses levantadas. Os resultados apresentados demonstram uma relação positiva e estatisticamente significante entre o $B r F \_S C O R E$ e $R E T \_A J$ para o grupo de todas empresas na amostra. Isto indica que a análise baseada nos fundamentos financeiros da empresa é útil para diferenciar empresas que terão maiores retornos de sua ação no futuro. De fato, a análise indica que cada ponto adicional de $B r F \_S C O R E$ representa uma variação positiva de cerca de $3,5 \%$ no retorno ajustado pelo mercado esperado 1 ano à frente. Quando a mesma regressão é realizada para o grupo de empresas com alto índice PL/P, tem-se, conforme esperado, um aumento na relevância do BrF_SCORE. Neste grupo, cada ponto adicional do índice agregado de sinais financeiros, representa aproximadamente um aumento de 7,5\% no retorno ajustado pelo mercado esperado 1 ano à frente. No grupo de empresas com baixo PL/P, o BrF_SCORE não é estatisticamente significante, o que aponta para uma diminuição de sua utilidade neste grupo de ações. Vale lembrar, que as ações com baixo índice PL/P (chamadas na literatura de growth stocks) normalmente são aquelas que obtiveram um bom desempenho no passado. Neste contexto, são ações mais líquidas, de empresas com maior valor de mercado e menos estressadas 
financeiramente (menor endividamento de curto prazo) ${ }^{52}$. A mesma análise pode ser feita com relação ao grupo de empresas com maior índice de governança. O BrF_SCORE não é estatisticamente significante, portanto não tem relação com os retornos futuros, para as empresas no quintil superior de governança, o que vai ao encontro da idéia de maior eficiência do mercado com relação às ações de empresas que apresentem menores níveis de assimetria informacional e, portanto, maior governança (KANAGARETNAM et al, 2007).

A análise dos coeficientes estimados na regressão do grupo de empresas com baixo BCGI, novamente aponta para a relevância do BrF_SCORE. Neste grupo a variação de 1 ponto no BrF_SCORE representa aproximadamente um aumento de $6,3 \%$ no retorno ajustado pelo mercado esperado 1 ano à frente. Na média, as empresas com baixo BCGI têm baixa liquidez da ação, maior endividamento de curto prazo e menor valor de mercado do que as empresas com níveis mais altos de governança ${ }^{53}$. Vale salientar, conforme apresentado na seção 4.2, que a interseção de empresas classificadas como alto PL/P e baixo BCGI resulta em 91 empresasperíodo, no total de $566^{54}$ empresas-período. Portanto, as características anteriormente avaliadas se referem, em grande parte, à empresas distintas nos dois grupos. Este ponto será mais explorado no item 5.6.

De modo a tornar a análise mais robusta, considera-se um termo de interação entre o nível de governança das empresas e o índice agregado de sinais financeiros (BCGI*BrF_SCORE). Conforme o esperado, dado os resultados anteriores, encontra-se um coeficiente com sinal negativo e estatisticamente significante, o que representa que o $B r F \_S C O R E$ tem uma maior utilidade para empresas com menor BCGI.

Em geral as análises realizadas na Tabela 5, painel A, apresentam uma relação negativa entre liquidez e retorno, demonstrando que é mais difícil "bater" o mercado no caso de empresas mais líquidas. Esta evidência é consistente com o conceito de eficiência de mercado, pela qual se pode supor que o preço das ações mais líquidas deve refletir mais acuradamente e tempestivamente os fundamentos das empresas, dificultando ganhos anormais de investidores com base em informações públicas (FAMA, 1970).

\footnotetext{
${ }^{52}$ Estas considerações são feitas com base nas estatísticas descritivas dos grupos. Estas informações são detalhadas no Apêndice D.

${ }^{53}$ Veja Apêndice D.

54307 empresas com alto PL/P + 350 empresas com baixo BCGI - 91 empresas com alto PL/P e baixo BCGI.
} 
O painel B da Tabela 5 apresenta os mesmos modelos estimados anteriormente, mas a variável dependente é o retorno ajustado pelo mercado 2 anos à frente (RET2_AJ). Apesar de uma diminuição na sua significância estatística, o $B r F \_S C O R E$ continua a diferenciar os retornos futuros para o grupo de empresas com alto PL/P (a 5\% de significância) e para o grupo de empresas com baixo BCGI (a 10\% de significância). Quando se considera os resultados da regressão com o termo de interação $\left(B C G I^{*} B r F \_S C O R E\right)$ para todas as empresas da amostra, o resultado obtido anteriormente se mantém, ou seja, o $B r F \_S C O R E$ aparenta diferenciar melhor os retornos futuros de ações de empresas com menores notas de governança.

O painel C da Tabela 5 apresenta os resultados da estimação dos modelos com dados em painel com efeitos fixos para assegurar a robustez dos resultados até aqui obtidos. Adicionalmente às variáveis anteriormente utilizadas, consideram-se os impactos dos retornos passados como previsores de retornos futuros (estratégias de momento). Este procedimento é consistente com as análises realizadas por Piotroski (2001). A variável MOMENTO representa os retornos da ação ajustados pelo mercado no período de seis meses antes da formação da carteira baseada na estratégia.

A estimação do modelo com dados em painel é realizada para todas as empresas na amostra e para os grupos de empresas com alto PL/P e para o grupo de empresas com baixo BCGI. Os resultados obtidos ratificam as análises anteriormente realizadas. A análise com dados em painel mostra que o BrF_SCORE é positivamente e significativamente relacionado com RET_AJ. Nesta estimação, cada ponto adicional de BrF_SCORE representa aproximadamente um aumento de: (i) 3,2\% no RET_AJ para todas empresas da amostra; (ii) 5,4\% para as empresas classificadas como alto PL/P e (iii) 6,5\% para as empresas consideradas com baixo BCGI. Finalmente, o painel $\mathrm{C}$ da Tabela 5 apresenta o resultado da regressão com dados em painel considerando o termo de interação $\left(B C G I^{*} B r F \_S C O R E\right)$ para todas as empresas da amostra. Novamente, a interpretação dos resultados não se altera, e demonstra uma relação significativa e negativa do termo $B C G I^{*} B r F \_S C O R E$. Isto indica que quanto maior o nível de governança da empresa, menor o poder de explicação do $B r F \_S C O R E$ com relação aos retornos futuros da ação.

Neste contexto, as próximas análises, que verificam diretamente os resultados obtidos com a implementação da estratégia de investimento baseada nas demonstrações contábeis, são realizadas para as empresas com alto PL/P, com baixo BCGI e para o grupo de empresas com alto PL/P e baixo BCGI. Espera-se que a efetividade da estratégia seja maior no último grupo. 
Tabela 5. Análise da associação do BrF_SCORE com os retornos de 1 ano e 2 anos à frente ajustados pelo mercado

Esta tabela apresenta o resultado das regressões em POLS (pooled ordinary least squares) e em painel com efeito fixo. Os painéis A e B apresentam a regressão para a explicação dos retornos ajustados pelo mercado para o período de 1 ano $\left(R E T \_A J\right)$ e para o período de 2 anos $\left(R E T 2 \_A J\right)$ a partir do $B r F \_S C O R E$ controlando pela liquidez da ação (LIQUIDEZ_AÇÃO), pelo tamanho da empresa $\operatorname{Ln}(A T I V O)$, pelo seu índice patrimônio-preço $\operatorname{Ln}(P L / P)$, pelo índice brasiliero de governança $(B C G I)$ e pela interação entre $B C G I$ e $B r F \_S C O R E$. Adicionalmente controla-se, mas não se reporta o resultado, pelo vetor de setores e por efeitos fixos de ano para todas as regressões. O painel $\mathrm{C}$ apresenta a estimação com base em dados em painel com efeito fixo para a explicação dos retornos ajustados pelo mercado para o período de 1 ano (RET_AJ) a partir do BrF_SCORE controlando pela liquidez da ação (LIQUIDEZ_AÇÃO), pelo tamanho da empresa Ln(ATIVO), pelo seu índice patrimônio-preço Ln(PL/P), pela variável de estratégia baseada em retorno passados (MOMENTO), pelo índice brasiliero de governança (BCGI) e pela interação entre BCGI e BrF_SCORE.Os erros padrões estimados são robustos à heterocedasticidade e à autocorrelação.* representa significância de 1\%, ** representa significância de 5\% e *** representa significância de $10 \%$.

\begin{tabular}{|c|c|c|c|c|c|c|c|c|c|c|}
\hline \multicolumn{11}{|c|}{ Coeficientes da regressão pooled - variável dependente: $R E T A, J$} \\
\hline $\begin{array}{l}\text { Todas as empresas } \\
\text { na amostra }\end{array}$ & $\begin{array}{r}\text { coeficiente } \\
\text { erro padrão } \\
\text { estat. t }\end{array}$ & $\begin{array}{c}\text { Intercepto } \\
-0,3711 \\
{[0,1969]} \\
-1,88 * * *\end{array}$ & $\begin{array}{c}\operatorname{Ln}(A T I V O) \\
-0,0001 \\
{[0,0128]} \\
-0,01\end{array}$ & $\begin{array}{c}\operatorname{Ln}(P L / P) \\
0,0914 \\
{[0,0205]} \\
4,46^{*}\end{array}$ & $\begin{array}{c}\text { LIQUIDEZ_AÇÃO } \\
-0,0253 \\
{[0,0132]} \\
-1,92 * *\end{array}$ & $\begin{array}{c}\text { BrF_SCORE } \\
0,0357 \\
{[0,0094]} \\
3,80^{*}\end{array}$ & $B C G I$ & $B C G I * B r F \_S C O R E$ & $\begin{array}{c}\mathrm{R}^{2} \text { Ajust. } \\
0,0923\end{array}$ & $\begin{array}{c}\mathrm{n} \\
1555\end{array}$ \\
\hline $\begin{array}{l}\text { Empresas com alto } \\
\text { (Q5) PL/P }\end{array}$ & $\begin{array}{r}\text { coeficiente } \\
\text { erro padrão } \\
\text { estat. t }\end{array}$ & $\begin{array}{c}-0,2439 \\
{[0,5396]} \\
-0,45\end{array}$ & $\begin{array}{c}-0,0347 \\
{[0,0383]} \\
-0,91\end{array}$ & $\begin{array}{c}0,1033 \\
{[0,0775]} \\
1,33\end{array}$ & $\begin{array}{c}0,1509 \\
{[0,0890]} \\
1,69 * * *\end{array}$ & $\begin{array}{c}0,0754 \\
{[0,0294]} \\
2,57 * *\end{array}$ & & & 0,1321 & 307 \\
\hline $\begin{array}{l}\text { Empresas com baixo } \\
\text { (Q1) BCGI }\end{array}$ & $\begin{array}{r}\text { coeficiente } \\
\text { erro padrão } \\
\text { estat. t }\end{array}$ & $\begin{array}{c}0,0710 \\
{[0,4968]} \\
0,14\end{array}$ & $\begin{array}{c}-0,0514 \\
{[0,0339]} \\
-1,52\end{array}$ & $\begin{array}{c}0,1148 \\
{[0,0504]} \\
2,28^{* *}\end{array}$ & $\begin{array}{c}-0,0190 \\
{[0,0815]} \\
-0,23\end{array}$ & $\begin{array}{c}0,0630 \\
{[0,0213]} \\
2,95^{*}\end{array}$ & & & 0,1529 & 350 \\
\hline $\begin{array}{l}\text { Empresas com alto } \\
\text { (Q5) BCGI }\end{array}$ & $\begin{array}{r}\text { coeficiente } \\
\text { erro padrão } \\
\text { estat. } t\end{array}$ & $\begin{array}{c}-0,2473 \\
{[0,6133]} \\
-0,40\end{array}$ & $\begin{array}{c}0,0121 \\
{[0,0397]} \\
0,30\end{array}$ & $\begin{array}{c}0,1444 \\
{[0,0570]} \\
2,53^{* *}\end{array}$ & $\begin{array}{c}-0,0475 \\
{[0,0440]} \\
-1,08\end{array}$ & $\begin{array}{c}-0,0224 \\
{[0,0249]} \\
-0,90\end{array}$ & & & 0,2878 & 217 \\
\hline
\end{tabular}


Tabela 5 - Continuação

Painel B

\begin{tabular}{|c|c|c|c|c|c|c|c|c|c|c|}
\hline \multicolumn{11}{|c|}{ Coeficientes da regressão pooled - variável dependente: $R E T 2 \_A J$} \\
\hline $\begin{array}{l}\text { Todas as empresas } \\
\text { na amostra }\end{array}$ & $\begin{array}{r}\text { coeficiente } \\
\text { erro padrão } \\
\text { estat. t }\end{array}$ & $\begin{array}{c}\text { Intercepto } \\
-0,8643 \\
{[0,5890]} \\
-0,54\end{array}$ & $\begin{array}{c}\operatorname{Ln}(A T I V O) \\
0,1112 \\
{[0,3660]} \\
0,91\end{array}$ & $\begin{array}{c}\operatorname{Ln}(P L / P) \\
0,2830 \\
{[0,0000]} \\
4,5^{*}\end{array}$ & $\begin{array}{c}\text { LIQUIDEZ_AÇÃO } \\
-0,1676 \\
{[0,0670]} \\
-1,83 * * *\end{array}$ & $\begin{array}{c}\text { BrF_SCORE } \\
0,0507 \\
{[0,0890]} \\
1,7 * * *\end{array}$ & $B C G I$ & $B C G I^{*} B r F \_S C O R E$ & $\begin{array}{c}\mathrm{R}^{2} \text { Ajust. } \\
0,0227\end{array}$ & $\begin{array}{c}\mathrm{n} \\
1555\end{array}$ \\
\hline $\begin{array}{l}\text { Empresas com alto } \\
\text { (Q5) PL/P }\end{array}$ & $\begin{array}{r}\text { coeficiente } \\
\text { erro padrão } \\
\text { estat. t }\end{array}$ & $\begin{array}{c}0,1427 \\
{[1,6961]} \\
0,08\end{array}$ & $\begin{array}{c}0,0500 \\
{[0,1333]} \\
0,37\end{array}$ & $\begin{array}{c}0,1627 \\
{[0,2064]} \\
0,79\end{array}$ & $\begin{array}{c}-0,5421 \\
{[0,3611]} \\
-1,50\end{array}$ & $\begin{array}{c}0,1926 \\
{[0,0932]} \\
2,07 * *\end{array}$ & & & 0,1081 & 307 \\
\hline $\begin{array}{l}\text { Empresas com baixo } \\
\text { (Q1) PL/P }\end{array}$ & $\begin{array}{r}\text { coeficiente } \\
\text { erro padrão } \\
\text { estat. } t\end{array}$ & $\begin{array}{c}-1,6034 \\
{[0,7569]} \\
-2,12 * *\end{array}$ & $\begin{array}{c}0,0648 \\
{[0,0432]} \\
1,50\end{array}$ & $\begin{array}{c}-0,0578 \\
{[0,1360]} \\
-0,43\end{array}$ & $\begin{array}{l}-0,0780 \\
{[0,0463]} \\
-1,68 * * *\end{array}$ & $\begin{array}{c}0,0431 \\
{[0,0369]} \\
1,17\end{array}$ & & & 0,1296 & 314 \\
\hline $\begin{array}{l}\text { Empresas com baixo } \\
\text { (Q1) BCGI }\end{array}$ & $\begin{array}{r}\text { coeficiente } \\
\text { erro padrão } \\
\text { estat. t }\end{array}$ & $\begin{array}{c}2,4258 \\
{[1,2172]} \\
1,99 * *\end{array}$ & $\begin{array}{c}-0,1159 \\
{[0,0777]} \\
-1,49\end{array}$ & $\begin{array}{c}0,3882 \\
{[0,1105]} \\
3,51 *\end{array}$ & $\begin{array}{c}0,0279 \\
{[0,1694]} \\
0,16\end{array}$ & $\begin{array}{c}0,0912 \\
{[0,0533]} \\
1,71 * * *\end{array}$ & & & 0,1819 & 350 \\
\hline $\begin{array}{l}\text { Empresas com alto } \\
\text { (Q5) BCGI }\end{array}$ & $\begin{array}{r}\text { coeficiente } \\
\text { erro padrão } \\
\text { estat. t }\end{array}$ & $\begin{array}{c}2,3175 \\
{[1,8576]} \\
1,25\end{array}$ & $\begin{array}{c}-0,0912 \\
{[0,1091]} \\
-0,84\end{array}$ & $\begin{array}{c}0,7526 \\
{[0,2122]} \\
3,55^{*}\end{array}$ & $\begin{array}{c}-0,0760 \\
{[0,1026]} \\
-0,74\end{array}$ & $\begin{array}{c}-0,0032 \\
{[0,0582]} \\
-0,05\end{array}$ & & & 0,3248 & 217 \\
\hline $\begin{array}{l}\text { Todas as empresas } \\
\text { na amostra }\end{array}$ & $\begin{array}{r}\text { coeficiente } \\
\text { erro padrão } \\
\text { estat. } t\end{array}$ & $\begin{array}{c}-1,3837 \\
{[1,6694]} \\
-0,83\end{array}$ & $\begin{array}{c}0,1113 \\
{[0,1280]} \\
0,87\end{array}$ & $\begin{array}{c}0,2700 \\
{[0,0632]} \\
4,27^{*}\end{array}$ & $\begin{array}{l}-0,1537 \\
{[0,0865]} \\
-1,78 * * *\end{array}$ & $\begin{array}{c}0,1619 \\
{[0,0495]} \\
3,27^{*}\end{array}$ & $\begin{array}{c}1,8220 \\
{[0,7224]} \\
2,52 * *\end{array}$ & $\begin{array}{c}-0,3602 \\
{[0,1473]} \\
-2,45^{* *}\end{array}$ & 0,0234 & 1543 \\
\hline \multicolumn{11}{|c|}{ Painel C } \\
\hline Coeficientes da regre & ão em painel & com efeitos & ixos - variável & dependente: & $\overline{R E T} \_A J$ & & & & & \\
\hline $\begin{array}{l}\text { Todas as empresas } \\
\text { na amostra }\end{array}$ & $\begin{array}{r}\text { coeficiente } \\
\text { erro padrão } \\
\text { estat. t }\end{array}$ & $\begin{array}{c}\text { Intercepto } \\
-0,3183 \\
{[0,1831]} \\
-1,74 * * *\end{array}$ & $\begin{array}{c}\operatorname{Ln}(A T I V O) \\
-0,0065 \\
{[0,0116]} \\
-0,57\end{array}$ & $\begin{array}{c}\operatorname{Ln}(P L / P) \\
0,1032 \\
{[0,0203]} \\
5,09^{*}\end{array}$ & $\begin{array}{c}\text { MOMENTO } \\
0,0000 \\
{[0,0004]} \\
-0,02\end{array}$ & $\begin{array}{c}B r F \_S C O R E \\
0,0317 \\
{[0,0097]} \\
3,26^{*}\end{array}$ & $B C G I$ & $B C G I^{*} B r F_{-} S C O R E$ & $\begin{array}{c}n \\
1467\end{array}$ & \\
\hline $\begin{array}{l}\text { Empresas com alto } \\
\text { (Q5) PL/P }\end{array}$ & $\begin{array}{r}\text { coeficiente } \\
\text { erro padrão } \\
\text { estat. t }\end{array}$ & $\begin{array}{c}-0,2278 \\
{[0,4749]} \\
-0,48\end{array}$ & $\begin{array}{c}-0,0373 \\
{[0,0337]} \\
-1,11\end{array}$ & $\begin{array}{c}0,1918 \\
{[0,0890]} \\
2,16^{* *}\end{array}$ & $\begin{array}{l}-0,0014 \\
{[0,0007]} \\
-1,84 * * *\end{array}$ & $\begin{array}{c}0,0537 \\
{[0,0300]} \\
1,79 * * *\end{array}$ & & & 275 & \\
\hline $\begin{array}{l}\text { Empresas com baixo } \\
\text { (Q1) BCGI }\end{array}$ & $\begin{array}{r}\text { coeficiente } \\
\text { erro padrão } \\
\text { estat. t }\end{array}$ & $\begin{array}{c}-0,1050 \\
{[0,4470]} \\
-0,23\end{array}$ & $\begin{array}{c}-0,0464 \\
{[0,0301]} \\
-1,54\end{array}$ & $\begin{array}{c}0,1242 \\
{[0,0414]} \\
3,00^{*}\end{array}$ & $\begin{array}{c}-0,0007 \\
{[0,0010]} \\
-0,70\end{array}$ & $\begin{array}{c}0,0646 \\
{[0,0217]} \\
2,98 *\end{array}$ & & & 320 & \\
\hline $\begin{array}{l}\text { Todas as empresas } \\
\text { na amostra }\end{array}$ & $\begin{array}{r}\text { coeficiente } \\
\text { erro padrão } \\
\text { estat. t }\end{array}$ & $\begin{array}{c}-0,7227 \\
{[0,2139]} \\
-3,38 *\end{array}$ & $\begin{array}{c}-0,0045 \\
{[0,0118]} \\
-0,38\end{array}$ & $\begin{array}{c}0,1065 \\
{[0,0210]} \\
5,07^{*}\end{array}$ & $\begin{array}{c}0,0000 \\
{[0,0004]} \\
-0,12\end{array}$ & $\begin{array}{c}0,1004 \\
{[0,0240]} \\
4,18 *\end{array}$ & $\begin{array}{c}1,1848 \\
{[0,3556]} \\
3,33^{*}\end{array}$ & $\begin{array}{c}-0,2065 \\
{[0,0609]} \\
-3,39 *\end{array}$ & 1458 & \\
\hline
\end{tabular}




\subsection{Utilidade da estratégia de investimentos baseada em informações contábeis}

A partir da análise anteriormente apresentada, pode-se proceder à investigação direta da utilidade da estratégia de investimento baseada nas demonstrações contábeis. Assim, inicialmente, formam-se carteiras igualmente ponderadas de ações separando-se por cada resultado do BrF_SCORE (de 1 a 9 pontos). Adicionalmente, formam-se carteiras de empresas com Alto Score (aquelas que receberam notas de 7 a 9), com Baixo Score (aquelas que receberam notas iguais ou menores do que 3) e uma carteira representativa de todas as empresas do grupo.

Para cada carteira, calcula-se a média, a mediana e os retornos representativos dos percentis de $10 \%$ (menores retornos), de $25 \%$, de $75 \%$ e de $90 \%$ (maiores retornos). Vale salientar que os retornos em análise são os adicionais aos obtidos pela carteira de mercado ${ }^{55}$ para 1 e 2 anos à frente da data de formação da carteira.

Neste ponto, a hipótese a ser avaliada é:

H1 - A seleção de uma carteira de ações composta por empresas fortes financeiramente dentro do grupo das empresas brasileiras negociadas em Bolsa gera retornos acima dos obtidos por uma carteira ampla de mercado.

Se a hipótese acima for verdadeira, os retornos apresentados pelas empresas de maior $B r F \_S C O R E$ devem ser maiores do que os apresentados por empresas classificadas com baixos índices, mesmo entre todas as empresas da amostra. Estas análises são feitas a partir dos retornos apurados em cada carteira e, principalmente, entre as carteiras de Alto Score, Baixo Score e do grupo total.

O painel A da Tabela 6 apresenta os resultados obtidos para as carteiras formadas considerandose todas as empresas da amostra. Os resultados mostram que o retorno de um ano ajustado pelo mercado obtido pela carteira das empresas com Alto Score é maior e estatisticamente significante do que o retorno obtido pela carteira de empresas com Baixo Score. O retorno médio (mediana) da carteira de Alto Score é 16 (20) pontos percentuais maior do que o retorno da carteira de empresas com Baixo Score. Esta diferença é estatisticamente e economicamente significante.

\footnotetext{
${ }^{55}$ Para detalhes veja o item 4.4.
} 
Tabela 6. Retornos da Estratégia baseada na análise de demonstrações contábeis para todas as empresas Esta tabela apresenta nos painéis A e B os retornos (para 1 e 2 anos) buy-and-hold da estratégia de investimento baseada nos sinais financeiros extraídos das demonstrações contábeis. Empresas classificadas como Baixo Score são aquelas que obtiveram notas agregadas (BrF_SCORE) de 1 a 3. Empresas classificadas como Alto Score são aquelas que obtiveram notas agregadas (BrF_SCORE) de 7 a 9.

\begin{tabular}{|c|c|c|c|c|c|c|c|}
\hline \multicolumn{8}{|c|}{ Painel A: Retrono de 1 ano ajustado pelo mercado } \\
\hline & Média & $\begin{array}{c}\text { Percentil } \\
10 \%\end{array}$ & $\begin{array}{c}\text { Percentil } \\
25 \%\end{array}$ & Mediana & $\begin{array}{c}\text { Percentil } \\
75 \%\end{array}$ & $\begin{array}{c}\text { Percentil } \\
90 \%\end{array}$ & $\mathrm{n}$ \\
\hline \multicolumn{8}{|l|}{ Todas empresas } \\
\hline da amostra & 0,0593 & $-0,6110$ & $-0,3778$ & $-0,0677$ & 0,3298 & 0,8108 & 1555 \\
\hline \multicolumn{8}{|l|}{ BrF_SCORE } \\
\hline 1 & $-0,0492$ & $-0,8955$ & $-0,3487$ & $-0,2557$ & 0,2089 & 1,3822 & 9 \\
\hline 2 & $-0,1445$ & $-0,7169$ & $-0,5020$ & $-0,3166$ & 0,1188 & 0,7238 & 48 \\
\hline 3 & $-0,0607$ & $-0,7122$ & $-0,4826$ & $-0,2134$ & 0,2062 & 0,6582 & 154 \\
\hline 4 & 0,0735 & $-0,6111$ & $-0,3739$ & $-0,0846$ & 0,3635 & 0,8838 & 271 \\
\hline 5 & 0,0192 & $-0,6180$ & $-0,4160$ & $-0,1052$ & 0,2473 & 0,6887 & 306 \\
\hline 6 & 0,1416 & $-0,5311$ & $-0,3132$ & 0,0416 & 0,4485 & 0,8843 & 318 \\
\hline 7 & 0,1304 & $-0,5297$ & $-0,3065$ & 0,0087 & 0,4515 & 0,9138 & 236 \\
\hline 8 & 0,0521 & $-0,5861$ & $-0,2691$ & $-0,0023$ & 0,2900 & 0,7662 & 150 \\
\hline 9 & $-0,0081$ & $-0,7246$ & $-0,4828$ & $-0,1242$ & 0,3802 & 0,7667 & 63 \\
\hline Baixo Score (1-3) & $-0,0793$ & $-0,7169$ & $-0,4826$ & $-0,2254$ & 0,2062 & 0,6724 & 211 \\
\hline Alto Score (7-9) & 0,0848 & $-0,5709$ & $-0,3166$ & $-0,0164$ & 0,3620 & 0,8108 & 449 \\
\hline Alto - Baixo & 0,1641 & 0,1460 & 0,1660 & 0,2090 & 0,1558 & 0,1384 & - \\
\hline estat-t/estat-z & 3,0383 & - & - & 4,017 & - & - & - \\
\hline ( $p$-Value) & $(0,0012)$ & - & - & $(0,0001)$ & - & - & - \\
\hline \multicolumn{8}{|l|}{ Result. Bootstrap } \\
\hline 1000 rep/estat-z & 2,9800 & - & - & 4,0300 & - & - & - \\
\hline$(p$-Value $)$ & $(0,0015)$ & - & - & $(0,0000)$ & - & - & - \\
\hline Alto - Todas & 0,0255 & - & - & - & - & - & - \\
\hline estat-t & 0,7204 & - & - & - & - & - & - \\
\hline$(p$-Value $)$ & $(0,2357)$ & - & - & - & - & - & - \\
\hline
\end{tabular}

Painel B: Retorno de 2 anos ajustado pelo mercado

\begin{tabular}{|c|c|c|c|c|c|c|c|}
\hline & Média & $\begin{array}{c}\text { Percentil } \\
10 \%\end{array}$ & $\begin{array}{c}\text { Percentil } \\
25 \%\end{array}$ & Mediana & $\begin{array}{c}\text { Percentil } \\
75 \%\end{array}$ & $\begin{array}{c}\text { Percentil } \\
90 \%\end{array}$ & $\mathrm{n}$ \\
\hline \multicolumn{8}{|l|}{ Todas empresas } \\
\hline da amostra & 0,3801 & $-0,9532$ & $-0,6039$ & $-0,0753$ & 0,6236 & 1,8009 & 1555 \\
\hline \multicolumn{8}{|l|}{ BrF_SCORE } \\
\hline 1 & $-0,1585$ & $-2,2396$ & $-0,7814$ & $-0,6094$ & 0,4031 & 2,5077 & 9 \\
\hline 2 & $-0,0139$ & $-1,3362$ & $-0,7652$ & $-0,3575$ & 0,4260 & 1,5131 & 48 \\
\hline 3 & 0,0383 & $-1,1338$ & $-0,7325$ & $-0,2091$ & 0,4840 & 1,4871 & 154 \\
\hline 4 & 0,2588 & $-0,9214$ & $-0,5769$ & $-0,1103$ & 0,5124 & 1,8271 & 271 \\
\hline 5 & 0,7314 & $-1,0477$ & $-0,6493$ & $-0,2271$ & 0,5065 & 1,6343 & 306 \\
\hline 6 & 0,3083 & $-0,8822$ & $-0,4964$ & 0,0078 & 0,8137 & 1,9474 & 318 \\
\hline 7 & 0,5645 & $-0,9488$ & $-0,5371$ & 0,0286 & 0,8482 & 2,1999 & 236 \\
\hline 8 & 0,3404 & $-0,8147$ & $-0,4602$ & 0,0756 & 0,6657 & 1,6293 & 150 \\
\hline 9 & 0,1746 & $-0,8420$ & $-0,5127$ & $-0,0468$ & 0,4228 & 1,5659 & 63 \\
\hline Baixo Score (1-3) & 0,0180 & $-1,1765$ & $-0,7530$ & $-0,2510$ & 0,4834 & 1,4871 & 211 \\
\hline Alto Score (7-9) & 0,4349 & $-0,9406$ & $-0,5127$ & 0,0257 & 0,7220 & 1,9558 & 449 \\
\hline Alto-Baixo & 0,4169 & 0,2359 & 0,2403 & 0,2767 & 0,2386 & 0,4687 & - \\
\hline estat-t/estat-z & 2,7458 & - & - & 3,672 & - & - & - \\
\hline$(p$-Value $)$ & $(0,0031)$ & - & - & $(0,0002)$ & - & - & - \\
\hline \multicolumn{8}{|l|}{ Result. Bootstrap } \\
\hline 1000 rep/estat-z & 3,7200 & - & - & 3,7400 & - & - & - \\
\hline ( $p$-Value) & $(0,0000)$ & - & - & $(0,0000)$ & - & - & - \\
\hline Alto - Todas & 0,0548 & - & - & - & - & - & - \\
\hline estat-t & 0,2808 & - & - & - & - & - & - \\
\hline$(p$-Value $)$ & $(0,3895)$ & - & - & - & - & - & - \\
\hline
\end{tabular}


Contudo, ao se comparar as alterações dos retornos das ações com Alto Score com o retorno da carteira de todas as empresas, o resultado da estratégia não aparenta ser eficiente. Um investidor que adotasse a estratégia de ficar comprado na carteira de empresas com Alto Score aumentaria seu retorno em relação à carteira de todas as empresas da amostra em 2,5 pontos percentuais (p.p.). Entretanto esta diferença não se mostrou estatisticamente significante.

As conclusões obtidas para a estratégia de investimento baseada em demonstrações contábeis para o conjunto total de empresas considerando-se um período de investimento de 2 anos são bastante similares às obtidas para a estratégia de 1 ano. Assim, o BrF_SCORE diferencia o retorno a frente das empresas com Alto Score em relação às de Baixo Score. Entretanto não se pode dizer o mesmo com relação ao retorno obtido pela carteira de todas as empresas.

As evidências encontradas não permitem que H1 seja confirmada. Nesse sentido prossegue-se a análise para as empresas com alto índice PL/P para se averiguar a eficácia da estratégia neste grupo de empresas.

\subsection{Utilidade da estratégia de investimentos baseada em informações contábeis para as empresas com alto PL/P}

A literatura de finanças (FAMA e FRENCH, 1995 e 1996) tem bem documentado que uma carteira de empresas com alto PL/P possuí maior retorno que a média de mercado. Piotroski (2000) foi pioneiro ao aplicar uma estratégia de investimento baseada na análise de indicadores contábeis para as empresas com alto PL/P e demonstrou que é possível melhorar os retornos, com relação aos obtidos com a carteira de empresas com alto PL/P, ao se selecionar empresas fortes financeiramente dentro deste grupo. Neste contexto, analisa-se a utilidade de uma estratégia semelhante para o Brasil, que apresenta um mercado com características diferenciadas em relação ao norte-americano. A hipótese a ser avaliada é:

$\mathbf{H 2}$ - A seleção de uma carteira de ações composta por empresas fortes financeiramente dentro do grupo das empresas com alto índice PL/P gera retornos anormais.

A Tabela 7 apresenta o resultado da aplicação da estratégia para as empresas com alto índice $\mathrm{PL} / \mathrm{P}$. 
Tabela 7. Retornos da Estratégia baseada na análise de demonstrações contábeis para empresas com alto PL/P Esta tabela apresenta nos painéis A e B os retornos (para 1 e 2 anos) buy-and-hold da estratégia de investimento baseada nos sinais financeiros extraídos das demonstrações contábeis para empresas com alto índice PL/P. Empresas classificadas como Baixo Score são aquelas que obtiveram notas agregadas (BrF_SCORE) de 1 a 3. Empresas classificadas como Alto Score são aquelas que obtiveram notas agregadas (BrF_SCORE) de 7 a 9.

\begin{tabular}{|c|c|c|c|c|c|c|c|}
\hline \multicolumn{8}{|c|}{ Painel A: Retrono de 1 ano ajustado pelo mercado } \\
\hline & Média & Percentil & Percentil & Mediana & Percentil & Percentil & $\mathrm{n}$ \\
\hline \multicolumn{8}{|l|}{ Todas empresas } \\
\hline c/alto $P L / P$ & 0,1945 & $-0,6067$ & $-0,3986$ & 0,0081 & 0,5047 & 1,4898 & 307 \\
\hline \multicolumn{8}{|l|}{ BrF_SCORE } \\
\hline 1 & $-0,3430$ & $-0,8949$ & $-0,8949$ & $-0,3430$ & 0,2089 & 0,2089 & 2 \\
\hline 2 & $-0,1254$ & $-0,7169$ & $-0,5422$ & $-0,2087$ & 0,2718 & 0,6724 & 15 \\
\hline 3 & 0,0604 & $-0,6329$ & $-0,4394$ & $-0,2071$ & 0,3297 & 1,0972 & 31 \\
\hline 4 & 0,2933 & $-0,4567$ & $-0,3348$ & 0,1441 & 0,5047 & 1,4898 & 58 \\
\hline 5 & $-0,0256$ & $-0,7647$ & $-0,5214$ & $-0,2046$ & 0,2448 & 0,7223 & 58 \\
\hline 6 & 0,2384 & $-0,6141$ & $-0,4098$ & 0,0823 & 0,5472 & 1,6071 & 71 \\
\hline 7 & 0,5315 & $-0,4740$ & $-0,1441$ & 0,2777 & 1,0540 & 1,6199 & 42 \\
\hline 8 & 0,1003 & $-0,4606$ & $-0,3160$ & $-0,0792$ & 0,3291 & 0,8108 & 25 \\
\hline 9 & 0,6278 & $-0,8498$ & $-0,7833$ & 0,4135 & 1,2929 & 3,0656 & 5 \\
\hline Baixo Score (1-3) & $-0,0145$ & $-0,7773$ & $-0,5420$ & $-0,2079$ & 0,2687 & 0,8897 & 48 \\
\hline Alto Score (7-9) & 0,3885 & $-0,4866$ & $-0,2242$ & 0,1691 & 0,7989 & 1,5610 & 72 \\
\hline Alto - Baixo & 0,4029 & 0,2907 & 0,3178 & 0,3770 & 0,5302 & 0,6713 & - \\
\hline estat-t/estat-z & 2,5178 & - & - & 2,853 & - & - & - \\
\hline ( $p$-Value) & $(0,0066)$ & - & - & $(0,0043)$ & - & - & - \\
\hline \multicolumn{8}{|l|}{ Result. Bootstrap } \\
\hline 1000 rep/estat-z & 2,4600 & - & - & 2,8900 & - & - & - \\
\hline$(p-$ Value $)$ & $(0,0070)$ & - & - & $(0,0040)$ & - & - & - \\
\hline Alto - Todas & 0,1939 & - & - & - & - & - & - \\
\hline estat-t & 1,7372 & - & - & - & - & - & - \\
\hline$(p$-Value $)$ & $(0,0416)$ & - & - & - & - & - & - \\
\hline \multicolumn{8}{|c|}{ Painel B: Retorno de 2 anos ajustado pelo mercado } \\
\hline & & Percentil & Percentil & & Percentil & Percentil & \\
\hline & Média & $10 \%$ & $25 \%$ & Mediana & $75 \%$ & $90 \%$ & $\mathrm{n}$ \\
\hline \multicolumn{8}{|l|}{ Todas empresas } \\
\hline c/alto PL/P & 0,7600 & $-0,9407$ & $-0,6137$ & 0,0405 & 1,2988 & 2,8596 & 307 \\
\hline \multicolumn{8}{|l|}{ BrF_SCORE } \\
\hline 1 & $-0,9504$ & $-1,1193$ & $-1,1193$ & $-0,9504$ & $-0,7814$ & $-0,7814$ & 2 \\
\hline 2 & 0,3758 & $-1,5449$ & $-0,7412$ & $-0,0613$ & 0,9546 & 3,8846 & 15 \\
\hline 3 & 0,0077 & $-0,9970$ & $-0,7592$ & $-0,2302$ & 0,2180 & 0,6372 & 31 \\
\hline 4 & 0,8716 & $-0,8262$ & $-0,4451$ & 0,2101 & 1,3931 & 3,4310 & 58 \\
\hline 5 & 0,0022 & $-1,2298$ & $-0,8079$ & $-0,4995$ & 0,2906 & 2,4018 & 58 \\
\hline 6 & 0,6338 & $-0,9021$ & $-0,5402$ & $-0,0536$ & 1,6004 & 2,2469 & 71 \\
\hline 7 & 2,5348 & $-0,5559$ & 0,2595 & 1,1513 & 2,5429 & 6,0950 & 42 \\
\hline 8 & 0,7770 & $-0,6900$ & $-0,4602$ & 0,0397 & 0,8591 & 1,4736 & 25 \\
\hline 9 & 1,5555 & $-0,5748$ & 0,6796 & 1,5659 & 2,7370 & 3,3697 & 5 \\
\hline Baixo Score (1-3) & 0,0828 & $-1,1884$ & $-0,7671$ & $-0,2057$ & 0,2298 & 2,1549 & 48 \\
\hline Alto Score (7-9) & 1,8565 & $-0,5887$ & $-0,2077$ & 0,7107 & 2,2006 & 4,8006 & 72 \\
\hline Alto - Baixo & 1,7736 & 0,5997 & 0,5594 & 0,9164 & 1,9708 & 2,6457 & - \\
\hline estat-t/estat-z & 3,0001 & - & - & 4,253 & - & - & - \\
\hline$(p$-Value $)$ & $(0,0016)$ & - & - & $(0,0000)$ & - & - & - \\
\hline \multicolumn{8}{|l|}{ Result. Bootstrap } \\
\hline 1000 rep/estat-z & 4,7400 & - & - & 4,7800 & - & - & - \\
\hline$(p-$ Value $)$ & $(0,0000)$ & - & - & $(0,0000)$ & - & - & - \\
\hline Alto - Todas & 1,0965 & - & - & - & - & - & - \\
\hline estat-t & 2,8681 & - & - & - & - & - & - \\
\hline$(p$-Value $)$ & $(0,0022)$ & - & - & - & - & - & - \\
\hline
\end{tabular}


O painel A da Tabela 7 mostra que carteiras de empresas com Alto Score obtém retornos médios ajustados pelo mercado para 1 ano a frente maiores do que as carteiras de empresas classificadas com Baixo Score. A diferença entre o retorno médio da carteira das empresas com Alto Score em comparação com as empresas de Baixo Score é de 40 p.p. e estatisticamente significante a $1 \%$. Da mesma maneira, a mediana do retorno da carteira das empresas fortes financeiramente é 38 p.p. maior (estatisticamente significante a 1\%) do que as empresas com baixas notas. Estes resultados são decorrentes, em grande parte, dos altos retornos obtidos pelas empresas dos grupos com altos BrF_SCORE. Pode-se perceber que o retorno das empresas com boas notas de BrF_SCORE classificados no percentil de $90 \%$ são significativamente maiores do que os obtidos pelas empresas com fracos indicadores financeiros.

Interessante avaliar também que há alteração na distribuição dos retornos das empresas classificadas como Alto Score em relação à carteira de todas as empresas com alto PL/P. Este resultado é significativo, pois mostra de fato que a análise de demonstrações contábeis agrega valor à estratégia de investimentos baseada na seleção de empresas com alto PL/P. Este resultado é consistente com o encontrado por Piotroski (2000) para o mercado norte americano, mas demonstra que a análise parece ter maior impacto em um mercado emergente como o Brasil. Nos resultados obtidos por Piotroski (2000), os retornos de um investidor que seleciona empresas com alto PL/P e com bons sinais financeiros aumentam pelo menos 7,5 p.p. ao ano e a estratégia tem maior consistência para o primeiro ano dos retornos. No mercado brasileiro este efeito aparenta ser mais forte e o aumento do retorno médio com a adoção da estratégia fica em torno de 19,4 p.p. e estatisticamente significante a $5 \%$. Tanto a média dos retornos, quanto a mediana (medida mais robusta a valores extremos) aumenta para o grupo de empresas com alto Br_FSCORE. Vale salientar que a robustez dos testes estatísticos é validada pelo procedimento de bootstrap, que confirma os resultados anteriormente obtidos. Os resultados obtidos no painel B da Tabela 7 para os retornos ajustados pelo mercado para 2 anos, também levam às mesmas conclusões, mas com aumento na significância estatística e nos valores obtidos de retorno.

Neste contexto, pode-se argumentar que os preços das ações com alto PL/P no mercado brasileiro aparentam ser mais defasados e convergem mais lentamente para os fundamentos do que os preços em mercados desenvolvidos. Entretanto, vale lembra que esta análise realizada leva em consideração outros fatores (como a liquidez das ações) que podem dificultar a sua realização na prática. Este tópico é abordado no item 5.7. 
A seguir, considera-se a análise com base nos indicadores financeiros para o grupo de empresas classificado com baixo nível de governança corporativa (baixo BCGI). Conforme demonstrado anteriormente a intersecção de empresas com alto PL/P e baixo BCGI é pequena, e espera-se que a estratégia seja eficiente também para este último grupo.

\subsection{Utilidade da estratégia de investimentos baseada em informações contábeis para as empresas com baixo BCGI}

Considerando-se as evidências de que empresas com melhores arranjos de governança corporativa apresentam menor nível de assimetria informacional (LOBO e ZHOU, 2001; KANAGARETNAM et al, 2007) e que menores níveis de assimetria resultam na maior eficiência do mercado com relação aos preços das ações, avalia-se a utilidade da estratégia de investimento baseada em demonstrações contábeis para as empresas consideradas com menor nível de governança, isto é, maior assimetria informacional.

As empresas com menor governança tendem a não utilizar canais diferenciados de comunicação com o mercado (como reuniões com analistas e uma área de relações com investidores ativa), o que torna as demonstrações contábeis a única fonte de informações financeiras da empresas com os fornecedores de capital externos à empresa. O painel $\mathrm{B}$ da Tabela 3 mostra que em comparação às empresas com alto PL/P, as empresas de baixo BCGI têm, na média, menor PL/P, maior valor de mercado, maior financiamento via capital de terceiros e maior rentabilidade. Os pontos aparentemente em comum entre as empresas dos dois grupos são a liquidez das ações e a concentração de endividamento no curto prazo.

Pode-se argumentar que a escolha de um grupo de empresas com base em um índice representativo da governança corporativa é um indicador mais estável que o PL/P, pois possuí volatilidade menor. Pelo painel A da Tabela 3 percebe-se que o ceoficiente de variação (desviopadrão/média) do BCGI é de 0,46 em comparação à 3,02 do PL/P. Assim, assume-se que a escolha de um grupo baseado no BCGI é menos sensível às variações do mercado do que a carteira formada pelas empresas de alto PL/P.

Neste contexto prossegue-se na investigação da terceira hipótese levantada:

H3 - A seleção de uma carteira de ações composta por empresas fortes financeiramente dentro do grupo das empresas com baixo BCGI resulta em retornos anormais. 
A Tabela 8 apresenta os resultados da estratégia de investimentos para o grupo de empresas com baixo BCGI (empresas no primeiro quintil da distribuição do BCGI). A análise dos resultados demonstra a efetividade da estratégia para este grupo de empresas, o que é uma novidade na literatura de análise de demonstrações contábeis.

O painel A da Tabela 8 apresenta os retornos ajustados pelo mercado 1 ano à frente da formação da carteira obtidos pelas ações das empresas com baixo BCGI. Percebe-se que as empresas com maiores valores de $B r F \_S C O R E$ apresentam um retorno maior do que as com performance financeira fraca. O retorno médio (mediana) da carteira de todas as empresas com baixo BCGI é de 6,7\% (-9,8\%) no ano, demonstrando que para este grupo de empresas não há o mesmo efeito que existe no grupo de empresas com alto PL/P, ou seja, um aumento do retorno em relação ao retorno da carteira de todas as empresas na amostra simplesmente pela seleção deste grupo de empresas.

Contudo, o painel A da Tabela 8 mostra que o BrF_SCORE diferencia significativamente o retorno das carteiras. As empresas classificadas como Alto Score obtiveram um retorno médio (mediana) de 25,3\% (2,3\%) em comparação à -26,7\% (-35,0\%) obtido pela carteira representada pelas ações com Baixo Score. Estas diferenças são signficantes ao nível de 1\%, confirmadas pelo procedimento de bootstrap. Adicionalmente, a diferença nos retornos obtidos pela carteira de empresas de Alto Score em comparação com as empresas de baixo BCGI é de 18,6 p.p., significante a $5 \%$.

Os resultados apresentados no painel B da Tabela 8, para os retornos ajustados para 2 anos, confirmam os resultados anteriormente encontrados e ratificam a eficácia do BrF_SCORE para a identificação de empresas com melhor performance futura dos retornos de suas ações. A diferença no retorno médio (mediana) da carteira de Alto Score para o retorno da carteira de Baixo Score é de 101,2 p.p. (significante a 1\%) no período acumulado de 2 anos, enquanto a diefrença no retorno médio da carteira de Alto Score para o retorno da carteira de todas as empresas com baixo BCGI é de 45,1 p.p. (significante a 5\%).

Assim, pode-se dizer que há evidências de que a análise de demonstrações contábeis é útil para a tomada de decisões de investimento em ações para empresas onde o nível de assimetria informacional é maior e para as quais, presumevelmente, a contabilidade é a fonte primária de informações para o mercado de capitais. 
Tabela 8. Retornos da Estratégia baseada na análise de demonstrações contábeis para empresas com baixo BCGI Esta tabela apresenta nos painéis A e B os retornos (para 1 e 2 anos) buy-and-hold da estratégia de investimento baseada nos sinais financeiros extraídos das demonstrações contábeis para empresas com baixo BCGI. Empresas classificadas como Baixo Score são aquelas que obtiveram notas agregadas (BrF_SCORE) de 1 a 3. Empresas classificadas como Alto Score são aquelas que obtiveram notas agregadas (BrF_SCORE) de 7 a 9.

\begin{tabular}{|c|c|c|c|c|c|c|c|}
\hline \multicolumn{8}{|c|}{ Painel A: Retrono de 1 ano ajustado pelo mercado } \\
\hline & & Percentil & Percentil & & Percentil & Percentil & \\
\hline & Média & $10 \%$ & $25 \%$ & Mediana & $75 \%$ & $90 \%$ & $\mathrm{n}$ \\
\hline \multicolumn{8}{|l|}{ Todas empresas } \\
\hline c/baixo BCGI & 0,0674 & $-0,7080$ & $-0,4024$ & $-0,0978$ & 0,3647 & 1,2011 & 350 \\
\hline \multicolumn{8}{|l|}{ BrF_SCORE } \\
\hline 1 & 0,1696 & $-0,8949$ & $-0,2919$ & $-0,0184$ & 0,6709 & 1,3822 & 5 \\
\hline 2 & $-0,2512$ & $-0,7169$ & $-0,5281$ & $-0,3579$ & $-0,2087$ & 0,1094 & 13 \\
\hline 3 & $-0,3312$ & $-0,8079$ & $-0,5265$ & $-0,3548$ & $-0,1271$ & 0,1514 & 37 \\
\hline 4 & 0,0776 & $-0,6826$ & $-0,3974$ & $-0,1255$ & 0,4016 & 1,2286 & 65 \\
\hline 5 & 0,0387 & $-0,7231$ & $-0,4563$ & $-0,1098$ & 0,2989 & 0,9181 & 72 \\
\hline 6 & 0,1288 & $-0,5893$ & $-0,3467$ & 0,0009 & 0,4662 & 0,9019 & 77 \\
\hline 7 & 0,3397 & $-0,4938$ & $-0,1682$ & 0,1899 & 1,1579 & 1,4382 & 42 \\
\hline 8 & 0,0487 & $-0,6897$ & $-0,2220$ & $-0,1429$ & 0,1482 & 1,1031 & 25 \\
\hline 9 & 0,3584 & $-0,4961$ & $-0,3824$ & $-0,0564$ & 1,1189 & 1,4837 & 14 \\
\hline Baixo Score (1-3) & $-0,2667$ & $-0,7773$ & $-0,5281$ & $-0,3505$ & $-0,0982$ & 0,2241 & 55 \\
\hline Alto Score (7-9) & 0,2531 & $-0,4961$ & $-0,2215$ & 0,0228 & 0,5719 & 1,3147 & 81 \\
\hline$\overline{\text { Alto - Baixo }}$ & 0,5199 & 0,2812 & 0,3066 & 0,3733 & 0,6701 & 1,0906 & - \\
\hline estat-t/estat-z & 4,4145 & - & - & 4,594 & - & - & - \\
\hline ( $p$-Value) & $(0,0000)$ & - & - & $(0,0000)$ & - & - & - \\
\hline \multicolumn{8}{|l|}{ Result. Bootstrap } \\
\hline 1000 rep/estat-z & 5,0200 & - & - & 5,3800 & - & - & - \\
\hline$(p-$ Value $)$ & $(0,0000)$ & - & - & $(0,0000)$ & - & - & - \\
\hline Alto - Todas & 0,1857 & - & - & - & - & - & - \\
\hline estat-t & 2,0385 & - & - & - & - & - & - \\
\hline$(p$-Value $)$ & $(0,0211)$ & - & - & - & - & - & - \\
\hline \multicolumn{8}{|c|}{ Painel B: Retorno de 2 anos ajustado pelo mercado } \\
\hline & & Percentil & Percentil & & Percentil & Percentil & \\
\hline & Média & $10 \%$ & $25 \%$ & Mediana & $75 \%$ & $90 \%$ & $\mathrm{n}$ \\
\hline \multicolumn{8}{|l|}{ Todas empresas } \\
\hline c/baixo BCGI & 0,3450 & $-0,9718$ & $-0,5847$ & $-0,0606$ & 0,7983 & 2,2103 & 350 \\
\hline \multicolumn{8}{|l|}{ BrF_SCORE } \\
\hline 1 & 0,1617 & $-1,1193$ & $-0,6094$ & $-0,3735$ & 0,4031 & 2,5077 & 5 \\
\hline 2 & $-0,2688$ & $-1,5449$ & $-1,3048$ & $-0,5360$ & 0,0280 & 1,0423 & 13 \\
\hline 3 & $-0,2485$ & $-1,4301$ & $-0,7123$ & $-0,2477$ & 0,2786 & 1,0338 & 37 \\
\hline 4 & 0,5839 & $-0,7691$ & $-0,4751$ & 0,0099 & 0,5755 & 2,8032 & 65 \\
\hline 5 & 0,1351 & $-1,1654$ & $-0,8331$ & $-0,2376$ & 0,4699 & 1,6343 & 72 \\
\hline 6 & 0,2657 & $-0,8668$ & $-0,4897$ & 0,0442 & 0,8928 & 1,6236 & 77 \\
\hline 7 & 0,9207 & $-0,7729$ & $-0,3838$ & 0,4487 & 1,9065 & 2,4772 & 42 \\
\hline 8 & 0,5336 & $-0,7201$ & $-0,3511$ & $-0,0085$ & 0,6657 & 2,8904 & 25 \\
\hline 9 & 0,8910 & $-0,6750$ & $-0,3256$ & 0,1835 & 2,1868 & 3,3697 & 14 \\
\hline Baixo Score (1-3) & $-0,2160$ & $-1,4301$ & $-0,8034$ & $-0,3789$ & 0,3111 & 1,0423 & 55 \\
\hline Alto Score (7-9) & 0,7961 & $-0,7201$ & $-0,3511$ & 0,3277 & 1,5824 & 2,8694 & 81 \\
\hline Alto-Baixo & 1,0121 & 0,7100 & 0,4523 & 0,7066 & 1,2713 & 1,8271 & - \\
\hline estat-t/estat-z & 3,8647 & - & - & 3,811 & - & - & - \\
\hline ( $p$-Value) & $(0,0001)$ & - & - & $(0,0001)$ & - & - & - \\
\hline \multicolumn{8}{|l|}{ Result. Bootstrap } \\
\hline 1000 rep/estat-z & 4,5000 & - & - & 4,0900 & - & - & - \\
\hline ( $p$-Value) & $(0,0000)$ & - & - & $(0,0000)$ & - & - & - \\
\hline Alto - Todas & 0,4511 & - & - & - & - & - & - \\
\hline estat-t & 2,1972 & - & - & - & - & - & - \\
\hline$(p$-Value $)$ & $(0,0143)$ & - & - & - & - & - & - \\
\hline
\end{tabular}




\subsection{Potencializando a estratégia de investimentos baseada em informações contábeis}

A quarta hipótese levantada diz respeito à utilização de estratégias de investimento baseada na análise de demonstrações contábeis para o grupo de empresas com alto PL/P e baixo BCGI. Os resultados anteriormente obtidos sugerem que a estratégia deveria funcionar, no mínimo, tão bem na intersecção do grupo de empresas com alto PL/P e baixo BCGI quanto funcionou individualmente nos grupos. Na amostra em análise são 91 empresas-período nesta situação. Assim, tem-se a quarta hipótese a ser investigada:

H4 - A utilidade da análise de demonstrações contábeis para seleção de carteiras de investimento é maior para empresas em situação de estresse financeiro (representado pelo alto indice PL/P) e com arranjos de governança corporativa mais fracos (baixo BCGI).

O painel A da Tabela 9 mostra que os retornos ajustados pelo mercado 1 ano à frente das carteiras com alto BrF_SCORE superam significativamente os retornos obtidos pelas carteiras de baixo BrF_SCORE para o grupo em análise. O retorno médio (mediana) da carteira de empresas com Alto Score é de 64,2\% (51,3\%) em relação a 17,5\% (-5,5\%) para todas as empresas do conjunto. A diferença no retorno médio de 46,6 p.p. é estatisticamente significante a um nível de $5 \%$. Quando se compara o resultado obtido com a carteira de empresas com Alto Score com a da carteira de Baixo Score, tem-se uma diferença de 108,6 p.p. com significância estatística de $1 \%$. Deve-se considerar como limitação o número reduzido de empresas-período obtido pela estratégia ao se restringir o grupo para empresas com alto PL/P e baixo BCGI. São 11 empresas classificadas como Baixo Score e 17 empresas como Alto Score. Contudo é importante ressaltar que as evidências apontam para o aumento da relevância da análise de demonstrações contábeis para este grupo específico de empresas.

O painel B da Tabela 9 apresenta os resultados para 2 anos e, novamente, confirma a utilidade da estratégia de investimento. Os retornos de 2 anos obtidos pela utilização da estratégia diferenciam significativamente entre as empresas de Alto Score e Baixo Score (com 1\% de significância) e entre o grupo de empresas com Alto Score e o total de empresas do conjunto (com 5\% de significância). Com base nestas evidências, pode-se dizer que a utilidade da análise de demonstrações contábeis é potencializada para o grupo de empresas com alto PL/P e baixo BCGI. 
Tabela 9. Retornos da Estratégia baseada na análise de demonstrações contábeis para empresas com alto PL/P e baixo BCGI

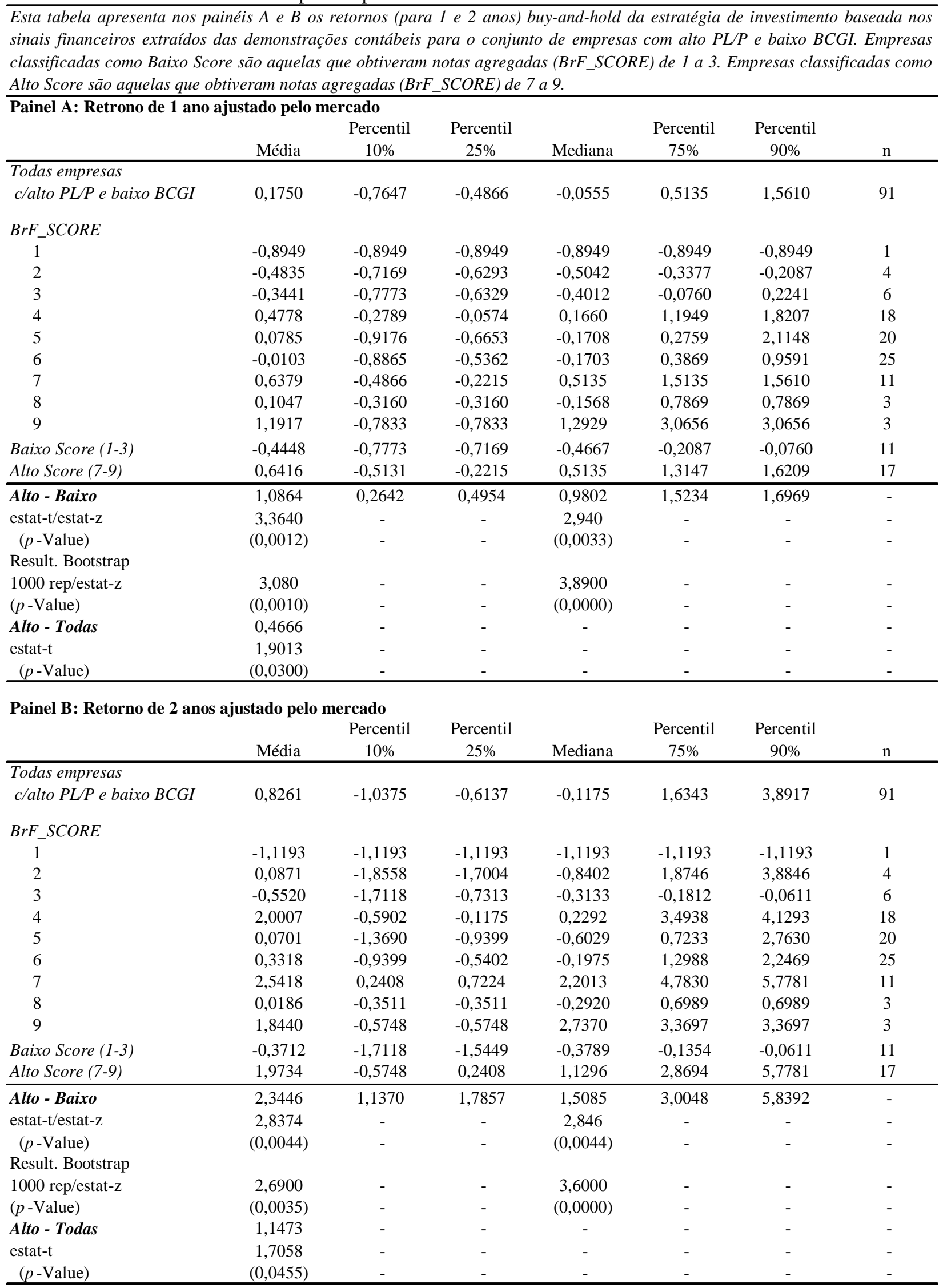


A seguir investigam-se quais são os fatores em comum entre as empresas com alto PL/P e baixo BCGI que podem explicar, pelo menos em parte, o sucesso da estratégia e não são captados pela análise anteriormente aplicada.

\subsection{Limitações da estratégia de investimentos baseada em informações contábeis}

Esta seção busca subsídios teóricos para explicar a aparente anomalia do mercado brasileiro referente aos retornos anormais obtidos com a aplicação das estratégias anteriormente analisadas. Outras anomalias, como a de empresas com alto índice PL/P (anomalia patrimônio-preço) e a dos accruals têm sido extensivamente estudadas. Lakonishok et al (1994) explicam a performance superior das ações com alto PL/P em relação às de baixo PL/P, com a hipótese de que os investidores avaliam erroneamente as ações com alto PL/P porque há uma reação exagerada em relação às baixas taxas de crescimento no passado. La Porta et al (1997a) mostram que os retornos anormais perto do período de publicação dos resultados são maiores para as empresas com ações value (uma das proxies são ações com alto PL/P) do que para ações glamour (baixo PL/P), o que é consistente com a hipótese de erros nas expectativas (LAKONISHOK et al, 1994). Outras explicações sobre a anomalia patrimônio-preço são apresentadas com base na captura dos riscos por parte do índice PL/P, (FAMA e FRENCH, 1993, 1996; DOUKAS et al, 1992). De acordo com a teoria clássica de finanças, maiores riscos devem resultar em maiores retornos, portanto faz sentido assumir que o PL/P seja uma boa proxy de risco da empresa. Entretanto, conforme discutido no item 2.2 não há consenso do porque a anomalia acorre.

Com relação à anomalia dos accruals as explicações também são controversas. Contudo, recentemente Mashruwala et al (2006) mostram que parte do efeito desta anomalia é explicada pela dificuldade de se implementar esta estratégia na prática, devido aos custos de transação, à não existência de oportunidades de arbitragem e ao alto risco idiossincrático das empresas selecionadas pela estratégia. Vale lembrar, com relação à anomalia dos accruals, que Pincus et al (2007) demonstram que este efeito está presente mais constantemente em mercados desenvolvidos.

O presente trabalho demonstra que a anomalia do efeito PL/P é incrementada ao se selecionar empresas com bons prospectos financeiros para um mercado com características diferenciadas do norte americano, reforçando os resultados obtidos por Piotroski (2000). Adicionalmente mostra- 
se que a estratégia de selecionar carteiras com empresas fortes financeiramente entre o grupo de empresas com baixa governança também é efetiva. Neste contexto, a próxima análise avalia a anomalia investigando características comuns nos dois grupos (alto PL/P e baixo BCGI) que possam estar relacionas com a obtenção de retornos anormais, mas não foram capturadas pelo $B r F \_S C O R E$. A hipótese levantada nesse sentido é:

H5 - As características de risco das empresas fortes financeiramente no grupo das empresas com alto índice PL/P e no grupo das de baixo BCGI são semelhantes e explicam o resultado obtido na estratégia de investimentos baseada na análise de demonstrações contábeis.

Bekaert et al (2006, p.1) comentam que os retornos esperados são influenciados pela liquidez das ações. Conforme apresentado na Tabela 5, a relação entre o índice de liquidez das ações e os retornos futuros da amostra total das empresas é negativa, demonstrando que quanto maior a liquidez da ação, menor a rentabilidade futura obtida com a ação. Esta evidência é consistente com a hipótese de eficiência do mercado. Entretanto, vale ressaltar que mesmo após o controle por liquidez, o BrF_SCORE se mantém significante para explicar os retornos futuros das empresas com alto PL/P, baixo BCGI e para o total da amostra, conforme apresentado na Tabela 5.

Outro ponto importante de ser avaliado refere-se aos riscos de falência das empresas. A literatura tradicional em finanças (ROSS et al, 1995; BREALEY e MYERS, 2000; BRIGHAM et al, 2001) comenta que a existência de custos associados à falência limita o montante de capital de terceiros que a empresa poderia utilizar. A estrutura de capital da empresa (participação de capital de terceiros em relação à participação de capital próprio) é um bom indicativo para este limite. Empresas com concentração excessiva de capital de terceiros em relação ao capital próprio tendem a ter mais dificuldades de honrar seus compromissos caso aconteça algum choque no planejamento anteriormente realizado. Considera-se neste trabalho que quanto maior a concentração do endividamento de curto prazo em relação ao endividamento total, maior a exposição da empresa à choques externos de curto prazo. Assim, esta variável também é incluída na análise.

Acredita-se que os fatores anteriormente mencionados (liquidez das ações e probabilidade de falência) possam não ser diretamente captados na estratégia implementada, considerando-se que o BrF_SCORE mensura a melhoria (piora) nos sinais financeiros da empresa, mas sem explicitar diretamente os montantes envolvidos. Ele mensura, por exemplo, a alteração na alavancagem da 
empresa e do seu índice de liquidez corrente, que são indicativos de melhoria (ou piora), mas não do estado atual. Com relação à liquidez das ações, o BrF_SCORE não mensura diretamente este fator de risco.

Assim, busca-se identificar, dentro dos grupos de empresas com alto PL/P e/ou baixo BCGI que receberam alta notas de BrF_SCORE, características relacionadas aos fatores de risco mencionados para a explicação dos resultados obtidos na estratégia. Este procedimento facilita a identificação dos possíveis fatores de risco mencionados que mais contribuem para a classificação da empresa em cada um dos grupos analisados. Para a análise inicial, apresentam-se as Figura 3 e Figura 4 com os Box-Plots por quintil do PL/P e do BCGI das variáveis representantes dos fatores de risco comentados.

As Figuras 3 e 4 apresentam o valor máximo, mínimo, a mediana, o primeiro quartil e o terceiro quartil das variáveis em divisões por quintil dos grupos selecionados. O eixo $x$ representa o quintil do grupo em análise, enquanto o eixo $y$ apresenta os valores da variável em análise. A alavancagem (ESTRUT_CAP) é calculada pela divisão da dívida total (curto e longo prazo) da empresa pelo total do capital investido nas suas atividades (dívida + patrimônio líquido). O índice de liquidez das ações (LIQUIDEZ_AÇÃO) é calculado pela seguinte fórmula ${ }^{56}$ : $100(p . P) \sqrt{(n . N / v \cdot V)}$, onde $p$ é o número de dias em que houve pelo menos um negócio com a ação dentro do período escolhido, $P$ é número total de dias do período escolhido, $n$ é o número negócios com a ação dentro do período escolhido, $N$ é o número de negócios com todas as ações dentro do período escolhido, $v$ é o volume em dinheiro com a ação dentro do período escolhido e $V$ é o volume em dinheiro com todas as ações dentro do período escolhido. A última variável representa o endividamento de curto prazo em relação ao de longo prazo (DÍVIDA_CP).

A análise dos painéis A das Figuras 3 e 4 demonstra que as empresas no quintil superior de PL/P e no quintil inferior de BCGI (os grupos de interesse) aparentemente possuem menor liquidez de suas ações e maior média de concentração de endividamento de curto prazo em relação ao endividamento de longo prazo. Com relação à estrutura de capital não se pode estabelecer visualmente um padrão.

\footnotetext{
${ }^{56}$ Utilizada pelo banco de dados Economatica.
} 
Figura 3. Características de risco por quintil do PL/P

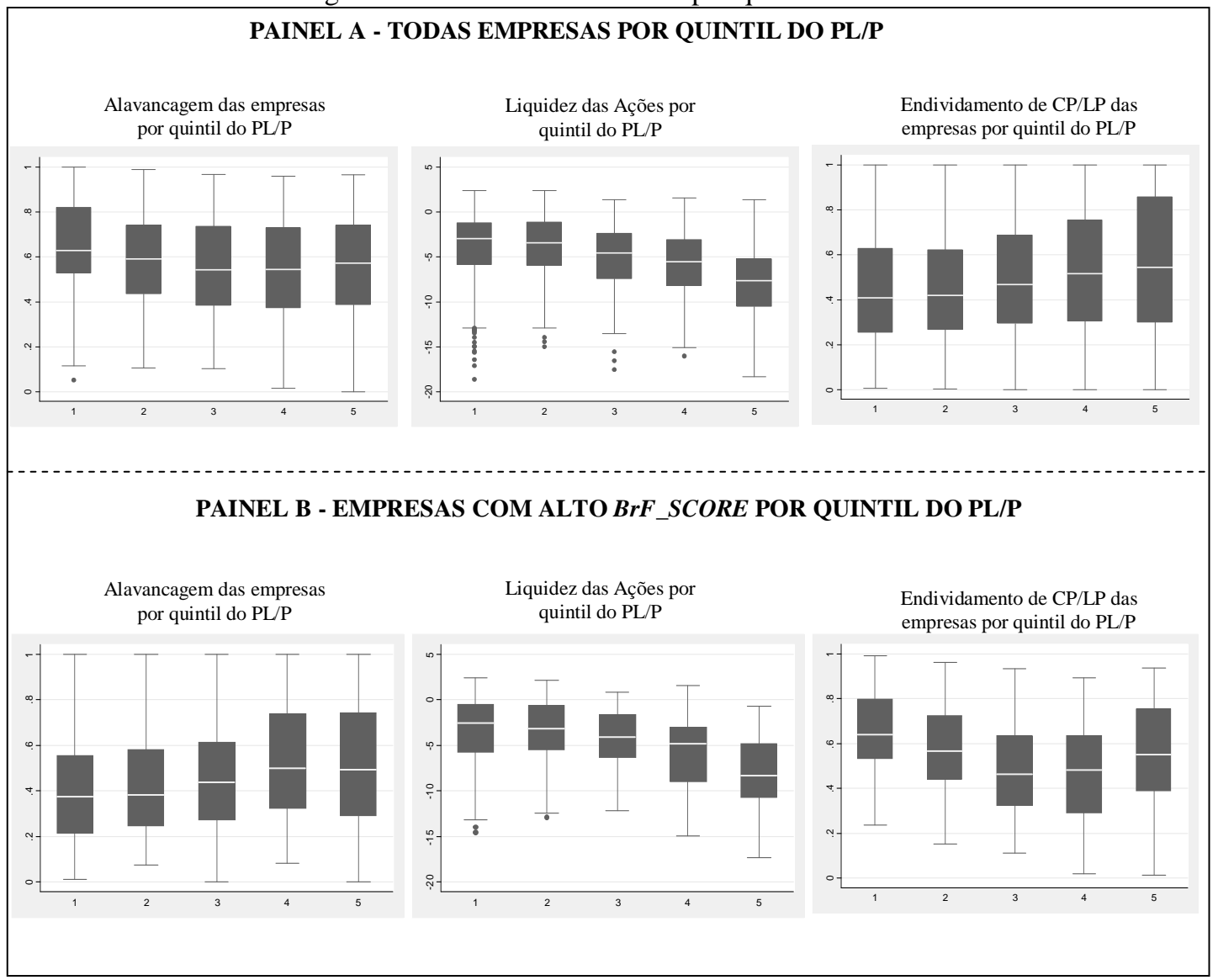

Figura 4. Características de risco por quintil do BCGI

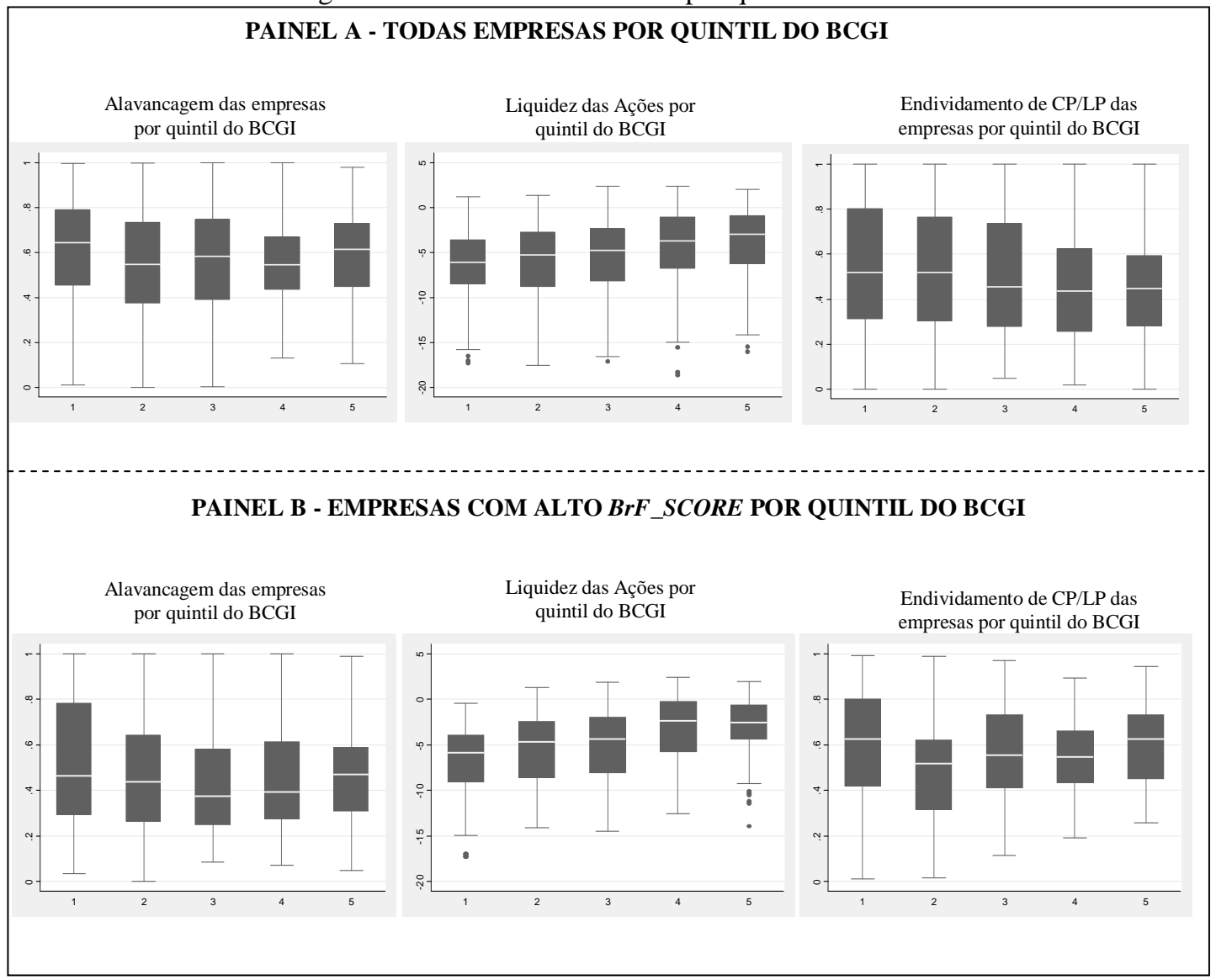


O painel B das Figuras 3 e 4 apresenta a mesma análise, mas para o grupo de empresas classificadas como Alto Score (BrF_SCORE $\geq 7)$. Para este grupo de empresas com bons indicadores financeiros, o fator de risco que parece mais diferenciar as empresas entre os quintis de alto e baixo PL/P ou BCGI (aqueles onde as estratégias baseadas em informações contábeis melhor funcionam) é a liquidez das ações na Bolsa.

No contexto apresentado, estima-se um modelo Pooled Probit para se identificar de forma mais robusta quais das características de risco em análise contribuem para a explicação de a empresa pertencer ou não ao grupo de empresas de baixo BCGI ou alto PL/P. Posteriormente aplica-se a mesma análise para as empresas com alto BrF_SCORE para avaliar se há alterações na significância dos fatores de risco.

A Tabela 10 mostra que dentre os fatores de risco analisados, os que mais contribuem para a classificação da empresa como alto PL/P (quintil superior) ou baixo BCGI (quintil inferior) são a liquidez da ação (significante a 1\%) e a concentração de dívida no curto prazo (significante a $10 \%$ ). Assim, quanto maior a liquidez da ação da empresa, menor a probabilidade dela ser classificada como alto PL/P ou baixo BCGI, enquanto quanto maior a concentração da dívida no curto prazo, maior a probabilidade de classificação nestes grupos.

Tabela 10. Contribuição dos fatores de risco para a classificação da empresa como alto PL/P ou baixo BCGI Esta tabela apresenta o resultado das regressões em Probit estimadas a partir de máxima-verossimilhança e considerando os efeitos fixos do setor da empresa e dos anos em análise. A variável dependente é uma DUMMY (D_CLASS) que se iguala a 1 se a empresa é classificada como alto PLP ou baixo BCGI, e O caso contrário. As variáveis explicativas são ESTRUT_CAP, LIQUIDEZ_AÇÃO e DÍVIDA_CP.Os erros padrões estimados são robustos à heterocedasticidade e à autocorrelação.* representa significância de $1 \%$, ** representa significância de $5 \%$ e *** representa significância de $10 \%$.

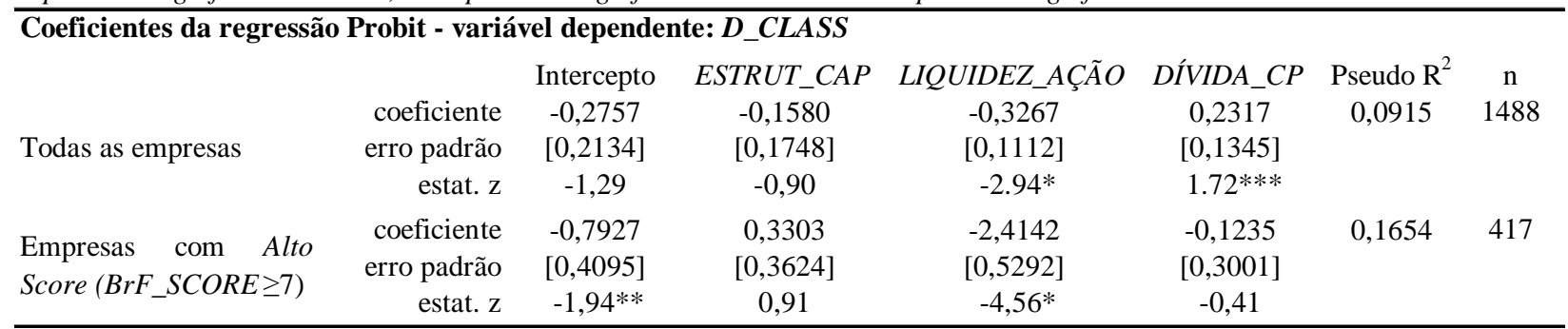

. LIQUIDEZ_AÇÃO - índice representativo da liquidez das ações na Bovespa. Quanto maior o valor, mais líquida a ação.

. DÍVIDA_CP - dívida de curto prazo dividida pelo endividamento de longo prazo no final do ano.

ESTRUT_CAP - relação entre o endividamento total da empresa e o total de recursos (capital próprio e capital de terceiros) no final do ano.

Adicionalmente, a Tabela 10 evidencia que quando se considera as empresas com bons indicadores financeiros (calculados pelo BrF_SCORE) o único fator de risco que diferencia a classificação das empresas no grupo de alto PL/P ou baixo BCGI é a liquidez das ações (significante a 1\%). Este resultado é relevante na medida em que demonstra que o sucesso da estratégia pode ser influenciado pela liquidez das ações. Importante salientar que os resultados 
encontrados na Tabela 5 em conjunto com os apresentados na Tabela 10 demonstram que altas notas de BrF_SCORE têm associação positiva com os retornos futuros das ações, contudo para se avaliar a possibilidade de implementação da estratégia deve-se levar em conta a liquidez das ações componentes da carteira, considerando que este é um fator de risco comum entre as empresas com alto $B r F \_S C O R E$ e classificadas como alto PL/P ou baixo BCGI.

Finalmente, avalia-se qual a liquidez, em termos de volume financeiro negociado, das carteiras por grupo de empresas selecionadas para a aplicação da estratégia. Investiga-se a existência de diferenças significativas nos volumes (em $\mathrm{R} \$$ mil/ano) negociados dos títulos que compõem cada uma das carteiras. O painel A da Tabela 11 apresenta os valores médios e as medianas do volume-período (em $\mathrm{R} \$ \mathrm{mil}$ ) negociado em Bolsa para as empresas classificadas por $B r F \_S C O R E$. Percebe-se que existem diferenças estatisticamente significantes de volume negociado para as empresas com alto BrF_SCORE e baixo BrF_SCORE entre o conjunto total de as empresas da amostra. Entretanto o mesmo não acontece para o conjunto de empresas classificadas como alto PL/P ou baixo BCGI. Parte deste resultado é conseqüência da grande variância do volume negociado por classificação de BrF_SCORE dentro destes grupos. Entretanto, percebe-se que a diferença entre a média (mediana) de volume negociado entre os grupos é relevante. Quando se considera a amostra total a média (mediana) do volume/ano é de $\mathrm{R} \$ 449,7$ milhões ( $\mathrm{R} \$ 10,3$ milhões). Entre as empresas de alto PL/P este valor é de $\mathrm{R} \$ 109,5$ milhões (R \$ 774 mil) e para as empresas de baixo BCGI R R R 92 milhões (R \$ 3,9 milhões). As grandes diferenças entre as médias e as medianas indicam que poucas empresas que são muito negociadas (de maior liquidez) influenciam nos valores médios podendo levar a distorções nas análises de possibilidade de implementação das estratégias. Para uma análise mais detalhada do volume negociado, considera-se as informações para cada ano de formação das carteiras.

O Painel B da Tabela 11 discrimina os valores médios e as medianas do volume (em R $\$$ mil) por ano para as empresas com alto BrF_SCORE e para os subgrupos de empresas com Alto Score $\left(B r F \_S C O R E \geq 7\right)$ e pertencentes ao grupo de alto PL/P ou baixo BCGI. Os resultados obtidos subsidiam a idéia de que a estratégia é possível de ser implementada, mas deve-se atentar para o volume aplicado. Vale lembrar que na intersecção dos grupos (alto PL/P e baixo BCGI) onde a estratégia se mostrou mais efetiva, a sua implementação fica bastante comprometida na prática por decorrência do pequeno número de empresas pertencentes a estes grupos (veja o painel D do apêndice E). O Painel B da Tabela 11 mostra que a média (mediana) das empresas com alto BrF_SCORE no grupo das empresas com alto PL/P é de R $\$ 19,5$ milhões/ano (R 695 mil/ano) e 
há períodos (por exemplo 2001) de muito baixa liquidez das ações que formam as carteiras. O mesmo efeito, porém aparentemente em menor escala, acontece para as empresas com alto BrF_SCORE no grupo de empresas com fraca governança (baixo BCGI). O volume negociado deste último grupo apresenta média (mediana) de $\mathrm{R} \$ 54,8$ milhões por empresa-ano (R \$ 6,2 milhões por empresa-ano), o que é um aumento relevante de liquidez ao se comparar com o grupo de empresas com alto $B r F \_S C O R E$ e alto PL/P.

Tabela 11. Volume-ano (em R \$ mil) negociado em Bolsa por carteira de $B r F \_S C O R E$ e por grupos selecionados Esta tabela apresenta no Painel A os valores médios e as medianas do volume-período (em $R \$$ mil/ano) negociado em Bolsa para as empresas classificadas por BrF_SCORE. O Painel B discrimina os valores médios e as medianas do volume (em $R \$$ mil) por ano para o grupo total de empresas com alto BrF_SCORE e para os subgrupos de empresas com Alto Score e pertencentes ao grupo de alto PL/P ou baixo BCGI. Empresas classificadas como Baixo Score são aquelas que obtiveram notas agregadas (BrF_SCORE) de 1 a 3. Empresas classificadas como Alto Score são aquelas que obtiveram notas agregadas (BrF_SCORE) de 7 a 9.

\begin{tabular}{|c|c|c|c|c|c|c|c|c|c|}
\hline \multicolumn{10}{|c|}{ 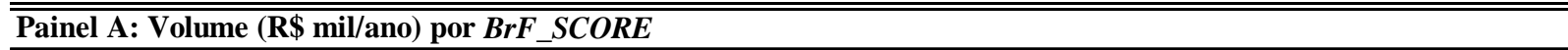 } \\
\hline & \multicolumn{3}{|c|}{ Todas Empresas } & \multicolumn{3}{|c|}{ Alto PL/P } & \multicolumn{3}{|c|}{ Baixo BCGI } \\
\hline & Média & Mediana & $\mathrm{n}$ & Média & Mediana & $\mathrm{n}$ & Média & Mediana & $\mathrm{n}$ \\
\hline Todas empresas & 449.724 & 10.336 & 1555 & 109.528 & 774 & 307 & 92.081 & 3.943 & 350 \\
\hline \multicolumn{10}{|l|}{ BrF_SCORE } \\
\hline 1 & 9.994 & 1.241 & 9 & 8.482 & 8.482 & 2 & 12.806 & 1.241 & 5 \\
\hline 2 & 80.528 & 9.248 & 48 & 40.111 & 2.711 & 15 & 33.945 & 6.982 & 13 \\
\hline 3 & 503.386 & 6.054 & 154 & 107.817 & 219 & 31 & 87.889 & 2.218 & 37 \\
\hline 4 & 238.006 & 5.117 & 271 & 223.936 & 925 & 58 & 207.321 & 3.821 & 65 \\
\hline 5 & 292.507 & 9.072 & 306 & 5.610 & 795 & 58 & 85.292 & 3.758 & 72 \\
\hline 6 & 458.649 & 9.025 & 318 & 210.420 & 664 & 71 & 57.339 & 3.813 & 77 \\
\hline 7 & 399.900 & 10.343 & 236 & 11.156 & 348 & 42 & 60.633 & 927 & 42 \\
\hline 8 & 1.169 .333 & 31.245 & 150 & 13.958 & 1.593 & 25 & 40.465 & 11.221 & 25 \\
\hline 9 & 765.252 & 30.832 & 63 & 118.656 & 19.970 & 5 & 62.912 & 15.202 & 14 \\
\hline Baixo Score (1-3) & 386.146 & 6.655 & 211 & 82.520 & 1.152 & 48 & 68.313 & 2.440 & 55 \\
\hline Alto Score (7-9) & 708.212 & 20.936 & 449 & 19.594 & 695 & 72 & 54.803 & 6.169 & 81 \\
\hline Alto - Baixo & 322.067 & 14.281 & - & -62.926 & -457 & - & -13.511 & 3.729 & - \\
\hline estat-t/estat-z & 1,5746 & 3,4530 & - & $-1,2758$ & 0,5840 & - & $-0,3917$ & $-0,3280$ & - \\
\hline ( $p$-Value) & $(0,0579)$ & $(0,0006)$ & - & $(0,8977)$ & $(0,5593)$ & - & $(0,6520)$ & $(0,7428)$ & - \\
\hline Alto - Todas & 258.488 & 10.600 & - & -89.934 & -79 & - & -37.278 & 2.227 & - \\
\hline estat-t & 2,2646 & $-3,2520$ & - & $-1,1776$ & 0,3700 & - & $-0,9111$ & 0,0530 & - \\
\hline ( $p$-Value) & $(0,0118)$ & $(0,0011)$ & - & $(0,8801)$ & $(0,7114)$ & - & $(0,8186)$ & $(0,7428)$ & - \\
\hline
\end{tabular}

\begin{tabular}{|c|c|c|c|c|c|c|c|c|c|}
\hline \multicolumn{10}{|c|}{ Painel B: Volume (R\$ mil) por ano das empresas alvo da estratégia (Alto Score por Grupos) } \\
\hline \multirow[b]{2}{*}{ Ano } & \multicolumn{3}{|c|}{ Alto Score (7-9) } & \multicolumn{3}{|c|}{ Alto Score (7-9) e Alto PL/P } & \multicolumn{3}{|c|}{ Alto Score (7-9) e Baixo BCGI } \\
\hline & Média & Mediana & $\mathrm{n}$ & Média & Mediana & $\mathrm{n}$ & Média & Mediana & $\mathrm{n}$ \\
\hline 1997 & 239.251 & 26.454 & 46 & 28.282 & 8.217 & 8 & 97.150 & 20.044 & 7 \\
\hline 1998 & 77.822 & 11.221 & 27 & 12.454 & 4.898 & 5 & 28.557 & 9.735 & 8 \\
\hline 1999 & 316.245 & 6.990 & 53 & 7.256 & 272 & 9 & 7.638 & 1.781 & 11 \\
\hline 2000 & 847.411 & 55.597 & 72 & 69.685 & 14.862 & 10 & 120.255 & 8.803 & 13 \\
\hline 2001 & 259.236 & 7.621 & 59 & 927 & 118 & 12 & 39.671 & 4.816 & 11 \\
\hline 2002 & 370.772 & 19.682 & 40 & 24.810 & 71 & 10 & 4.302 & 415 & 10 \\
\hline 2003 & 1.119 .093 & 21.460 & 72 & 2.558 & 703 & 9 & 36.845 & 8.133 & 9 \\
\hline 2004 & 1.455 .068 & 53.043 & 80 & 8.650 & 357 & 9 & 89.346 & 31.487 & 12 \\
\hline 1997 a 2004 & 708.212 & 20.936 & 449 & 19.594 & 695 & 72 & 54.803 & 6.169 & 81 \\
\hline
\end{tabular}


A partir dos dados apresentados anteriormente na Tabela 11 pode-se conjecturar que as empresas com alto Score e baixo BCGI têm ações mais líquidas que as empresas com alto Score e alto PL/P. Com intuito de se avaliar se as diferenças de volume negociado entre os grupos em análise, apresenta-se a Tabela 12 com as diferenças de médias e medianas de volume negociado no ano das ações pertencentes a cada grupo e os respectivos resultados dos testes estatísticos de diferenças.

Tabela 12. Diferenças de Volume (em $\mathrm{R} \$$ mil/ano) por grupo

Esta tabela apresenta os valores e os resultados dos testes das diferenças entre as médias e medianas do volume (em R\$ mil/ano) negociado em Bolsa para os principais pares de subgrupos. Empresas com Alto Score são aquelas com BrF_SCORE maior ou igual a 7. Empresas no grupo de alto PL/P são aquelas que foram classificadas no último quintil da relação patrimônio-preço. Empresas com baixo BCGI são aquelas que ficaram no primeiro quintil pela classificação por BCGI.

\begin{tabular}{|c|c|c|c|c|c|c|}
\hline & \multicolumn{2}{|c|}{$\begin{array}{c}\text { Todas - } \\
\text { Alto } P L / P\end{array}$} & \multicolumn{2}{|c|}{$\begin{array}{c}\text { Todas - } \\
\text { Baixo BCGI }\end{array}$} & \multicolumn{2}{|c|}{$\begin{array}{l}\text { Alto PL/P - } \\
\text { Baixo BCGI }\end{array}$} \\
\hline \multirow{6}{*}{$\begin{array}{l}\text { Diferença } \\
\text { estat-t/estat-z } \\
(p-\text { Value }) \\
\end{array}$} & Média & Mediana & Média & Mediana & Média & Mediana \\
\hline & 340.196 & 9.562 & 357.644 & 6.394 & 17.448 & -3.169 \\
\hline & 3,0464 & 11,432 & 3,4436 & 5,001 & 0,4336 & $-6,373$ \\
\hline & $(0,0012)$ & $(0,0000)$ & $(0,0003)$ & $(0,0000)$ & $(0,3324)$ & $(0,0000)$ \\
\hline & \multicolumn{2}{|c|}{$\begin{array}{c}\text { Alto Score - } \\
\text { Alto Score e Alto PL/P }\end{array}$} & \multicolumn{2}{|c|}{$\begin{array}{c}\text { Alto Score - } \\
\text { Alto Score e Baixo BCGI }\end{array}$} & \multicolumn{2}{|c|}{$\begin{array}{l}\text { Alto Score e Alto PL/P - } \\
\text { Alto Score e Baixo BCGI }\end{array}$} \\
\hline & Média & Mediana & Média & Mediana & Média & Mediana \\
\hline Diferença & 688.618 & 20.241 & 653.410 & 14.767 & -35.209 & -5.474 \\
\hline estat-t/estat-z & 2,1613 & 6,861 & 2,1749 & 4,072 & $-1,8675$ & $-2,835$ \\
\hline ( $p$-Value) & $(0,0156)$ & $(0,0000)$ & $(0,0150)$ & $(0,0000)$ & $(0,0319)$ & $(0,0046)$ \\
\hline
\end{tabular}

Os resultados apresentados na Tabela 12 são importantes para se confirmar alguns dos comentários anteriormente realizados, mas a principal conclusão é que há uma diferença significativa no volume negociado (pelo teste de média e mediana) das ações do grupo de empresas com alto $B r F \_S C O R E$ e baixo BCGI em relação às ações do grupo de alto BrF_SCORE e alto PL/P. Esta evidência é relevante na medida que amplia a aplicabilidade da estratégia original (PIOTROSKI, 2000) que se baseava apenas nas empresas fortes financeiramente dentro do grupo de alto PL/P.

\subsection{Robustez dos resultados por ano}

No sentido de se avaliar os resultados da aplicação da estratégia anualmente, o apêndice E separa os retornos de 1 ano ajustados pelo mercado obtidos com a formação das carteiras de Alto $B r F \_S C O R E$, Baixo BrF_SCORE e o conjunto total de empresas em cada grupo analisado. Percebe-se que as estratégias apresentadas são robustas às partições por ano, demonstrando que 
na grande maioria das vezes a carteira formada pelas empresas fortes financeiramente obtiveram maiores retornos médios anuais do que os outros grupos. Apesar de a estratégia ter funcionado de forma mais intensa (obtendo maiores retornos) para o conjunto de empresas com alto PL/P e baixo BCGI, vale salientar que o número de empresas-período para as quais a estratégia foi avaliada neste subconjunto é reduzido, portanto generalizações devem ser vista com restrições. De maneira geral, as evidências apontam para a robustez dos resultados obtidos com a estratégia de investimentos baseadas em informações contábeis para o mercado de capitais brasileiro, mesmo considerando-se o efeito liquidez discutido anteriormente. 


\section{CONCLUSÕES}

Este trabalho investiga a utilidade da análise de demonstrações contábeis para a seleção de carteiras de investimentos em ações. Demonstra-se que mesmo sob as características específicas do mercado e do regime contábil brasileiro as estratégias de investimento baseadas em informações contábeis são úteis para a seleção de carteiras que gerem retornos anormais significativos.

A primeira análise é realizada para o grupo de todas as empresas listadas na Bovespa. Os resultados indicam que a seleção de uma carteira de empresas fortes financeiramente dentro do grupo de todas as empresas não resulta em retornos estatisticamente diferentes dos obtidos ao se selecionar uma carteira com todas as empresas na amostra. Este resultado pode ser explicado com base no conceito de eficiência da forma semi-forte do mercado, onde os preços deveriam refletir todas as informações divulgadas (FAMA, 1970). Assim, não faria sentido se obter retornos anormais com base em análise de balanços nestas condições. Contudo esta situação pode ser estressada ao se considerar a seleção de empresas fortes financeiramente (a partir de dados extraídos de suas demonstrações contábeis) dentro de grupos com características específicas.

A segunda análise realizada investiga a utilidade para o mercado brasileiro da estratégia desenvolvida por Piotroski (2000). Esta estratégia seleciona empresas com bons indicadores financeiros dentre as empresas com alto índice PL/P. O índice PL/P pode ser considerado como uma proxy para o risco da empresa (FAMA e FRENCH, 1993). Piotroski (2000) também considera que empresas com alto PL/P são mais estressadas financeiramente e nestas situações a análise de demonstrações contábeis deveria ser de maior utilidade para a identificação de sinais financeiros relacionados com o desempenho futuro da empresa. As evidências encontradas neste trabalho mostram que o retorno anormal de uma carteira de empresas com alto PL/P aumenta em 19,4 p.p. passando de $19,4 \%$ a.a. para $38,8 \%$ a.a. ao se selecionar as empresas com alto BrF_SCORE e manter a carteira por um ano. Quando se considera a manutenção da carteira por dois anos os resultados são ainda mais significativos e o retorno anormal aumenta 109,6 p.p., passando de $76 \%$ para $185,6 \%$ no período ( 2 anos). Importante salientar que os retornos anormais considerados neste trabalho são aqueles acima dos obtidos pelo IBRX. Esta análise foca na seleção de empresas fortes financeiramente (alto BrF_SCORE) dentre o grupo de empresas com alto índice PL/P. Apesar de se demonstrar que a análise é útil mesmo após se controlar os efeitos 
de liquidez das ações componentes do grupo de alto PL/P, reconhece-se que sua implementação sofre restrições ao se avaliar o volume financeiro negociado.

Adicionalmente considera-se a utilidade da estratégia de investimentos ao se selecionar empresas com alto BrF_SCORE dentre o grupo de empresas com baixa governança corporativa (baixo BCGI). Este grupo é avaliado, pois há evidências de que empresas com maior governança possuem menores níveis de assimetria (KANAGARETNAM et al, 2007). Assim, empresas com governança mais fraca tendem a ter os seus fundamentos refletidos de forma menos eficiente no preço de suas ações. Também se demonstra, por meio de um modelo teórico desenvolvido neste trabalho $^{57}$, que maiores níveis de governança causam impactos positivos nos preços das ações. Estes elementos contribuem com a idéia de que a análise de demonstrações contábeis deveria ter uma utilidade maior para prever retornos futuros no grupo de empresas com menor nível de governança. As evidências encontradas ratificam a utilidade da análise de demonstrações contábeis para seleção de investimento em ações no grupo de empresas com menor governança. O retorno anormal de uma carteira de empresas com baixo BCGI aumenta em 18,5 p.p. passando de $6,7 \%$ a.a. para $25,3 \%$ a.a. ao se selecionar as empresas com alto BrF_SCORE e manter a carteira por uma ano. Para a carteira de dois anos os resultados são ainda melhores e o retorno anormal aumenta 45,1 p.p., passando de $34,5 \%$ para $79,6 \%$ no período ( 2 anos). Apesar do montante obtido de retorno ser maior para o grupo de empresas com alto PL/P, há vantagens nesta última estratégia. Ao se avaliar a liquidez das ações com alto BrF_SCORE e baixo BCGI em relação às empresas com alto BrF_SCORE e alto PL/P, nota-se uma alteração significativa no volume financeiro negociado. Estas evidências demonstram ser possível a implementação prática da estratégia para volumes moderados de recursos investidos. Importante ressaltar que do total das 566 empresas classificadas como ou alto PL/P (307) ou baixo BCGI (350), apenas 16\% (91) das empresas são classificadas como alto PL/P e baixo BCGI, mostrando que há diferença entre as empresas formadoras dos dois grupos.

Considerando a efetividade da estratégia de investimento baseada na análise de informações contábeis tanto para o grupo de empresas com baixo BCGI quanto para o grupo de empresas alto PL/P, elabora-se uma terceira estratégia baseada na seleção de empresas fortes financeiramente que pertençam simultaneamente ao grupo de empresas com baixo BCGI e alto PL/P. Esta estratégia resultou em retornos superiores aos anteriormente encontrados, mas demonstrou-se de

\footnotetext{
${ }^{57}$ Ver seção 3.
} 
menor aplicabilidade prática ao se considerar o número reduzido de empresas e o baixo volume financeiro negociado das ações.

A Figura 5 apresenta os resultados encontrados de forma esquemática. Basicamente, as evidências apontam para uma maior relevância da análise de balanços para a seleção de uma carteira de ações nos grupos de empresas com alto risco (alto PL/P) e maiores níveis de assimetria informacional (baixo BCGI). Estas empresas apresentam menor liquidez do que outras ações no mercado de capitais, menor exposição e tendem a ser menos acompanhadas pelos intermediários financeiros (analistas de equity, empresas de rating, entre outros). Estes fatores, associados ao baixo nível de eficiência do mercado de capitais brasileiro, podem explicar os resultados obtidos, pois tornam mais difícil a implementação da estratégia e diminuem a disseminação da informação em relação a outras ações negociadas na Bolsa de Valores.

Figura 5. Empresas onde a estratégia apresenta melhores resultados

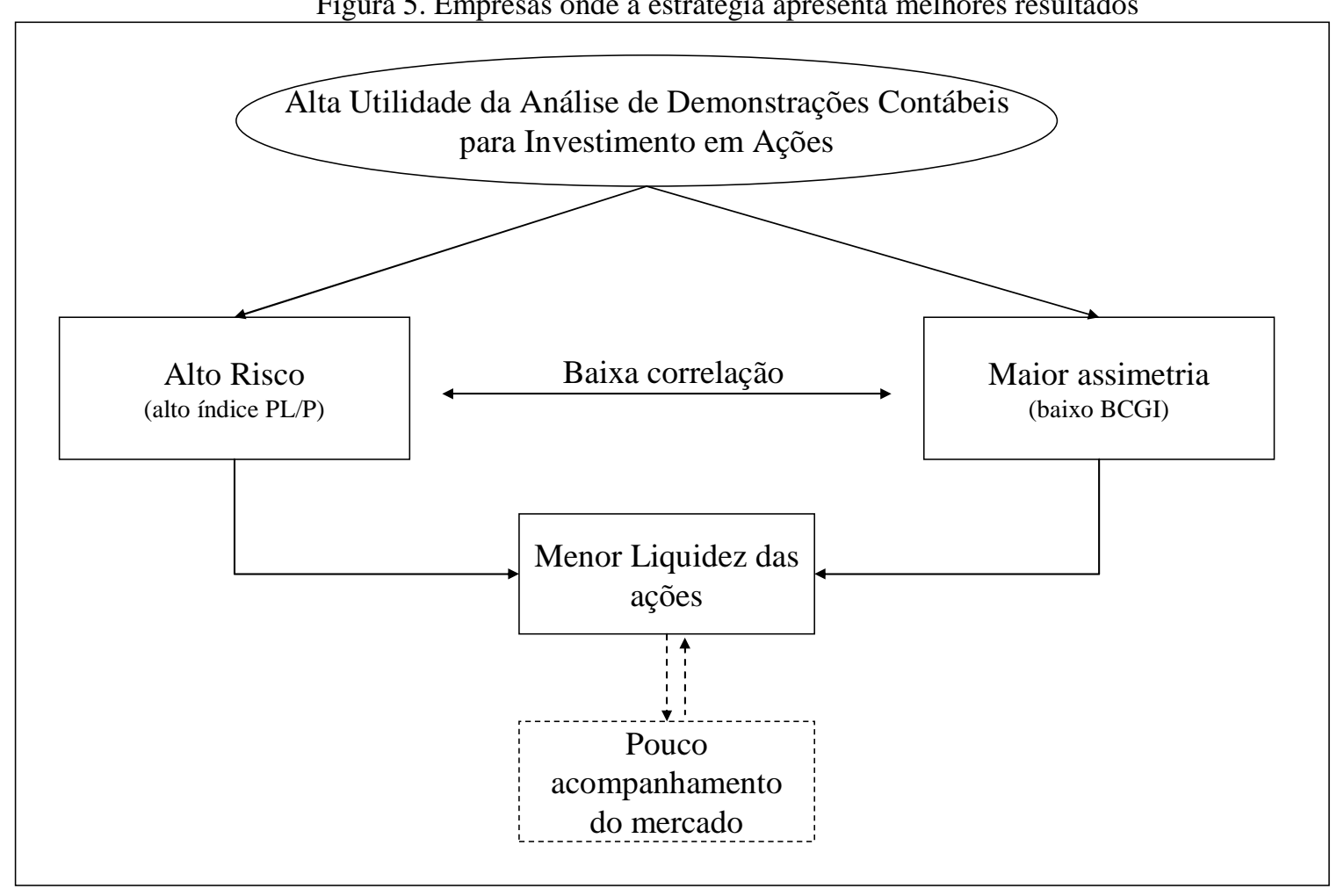

Trabalhos futuros podem adicionar características para melhor explicar o sucesso das estratégias de investimento baseadas na análise de demonstrações contábeis. Sugere-se que seja avaliado diretamente o número de reuniões que a empresas faz com o mercado, o número de analistas que acompanham a empresa e a participação societária de fundos de investimento nacionais e estrangeiros. Também se sugere a inclusão de outros elementos presentes no processo de avaliação de empresas (valuation) de modo a identificar se outras análises, como por exemplo a 
análise estratégica ou a análise da qualidade contábil (PALEPU et al, 2004), agregam valor ao processo de avaliação de empresas.

Vale salientar que a investigação efetuada neste trabalho restringe-se à avaliação da possibilidade da utilização da análise de demonstrações contábeis para a seleção de carteiras de investimento que resultem em retornos anormais positivos. A análise de balanços pode ser aplicada com outros objetivos, como análise de performance, avaliação de crédito, análise de liquidez e rentabilidade, entre outras, que não foram aqui investigadas.

Finalmente deve-se comentar sobre as recentes alterações nos modelos contábeis ao redor do mundo e da crescente utilização do fair value nos modelos do FASB, do IASB e, recentemente, no modelo brasileiro $^{58}$. Este tipo de mensuração considera, sempre que possível, o valor de mercado, ou uma proxy desse valor. A argumentação usualmente utilizada pelos órgãos normatizadores para a alteração da base de mensuração na contabilidade é a de maior relevância do fair value sobre o custo histórico para determinados itens do balanço. Contudo, esta argumentação é retórica no sentido que não há evidências conclusivas sobre qual das métricas apresenta uma informação mais útil para o usuário das demonstrações contábeis. Este trabalho, assim como outros estudos que avaliam decisões de investimentos baseadas em informações contábeis (ABARBANELL e BUSHEE, 1997; LEV e THIAGARAJAN, 1993; FAMA e FRENCH 1993; 1996; LAKONISHOK et al, 1994; ROSENBERG et al, 1984; DOUKAS et al, 2002; PIOTROSKI, 2000; MOHANRAN, 2005) utilizaram dados de períodos onde o modelo contábil era baseado, primordialmente, no custo histórico e encontraram evidências da relevância desta informação para a seleção de carteiras de investimento em ações. Recentemente Platin et al (2007) mostraram analiticamente que a contabilidade com base no fair value tem vantagens e desvantagens sobre a baseada no custo histórico. Especificamente os autores mostram que para ativos com duração curta, a marcação a mercado leva a menores ineficiências do que o custo histórico, mas o contrário é verdadeiro para ativos de longo prazo. As mesmas conclusões são obtidas para ativos líquidos (menor ineficiência do fair value) e ilíquidos (menor ineficiência do custo histórico).

\footnotetext{
${ }^{58}$ Com a aprovação da lei 11.638/07, a contabilidade das empresas brasileiras passa a convergir rapidamente para as normas internacionais. Tanto o Banco Central (Comunicado 14.259/06) quanto a CVM (Instrução 457/07) já se posicionaram favoravelmente à convergência do modelo contábil brasileiro para o modelo do IASB. A partir de 2010 as instituições financeiras e as companhias abertas deverão apresentar as demonstrações contábeis consolidadas com base no padrão contábil internacional.
} 
Uma pergunta interessante a ser respondida no futuro diz respeito a possíveis alterações na utilidade da análise das demonstrações contábeis com a implementação do modelo misto de mensuração contábil (custo histórico e fair value convivendo juntamente nas demonstrações contábeis). Acredita-se que este será um tema de alta relevância para a pesquisa em contabilidade. 


\section{REFERÊNCIAS}

ABARBANELL, J.; BUSHEE, B. Abnormal Returns to a Fundamental Analysis Strategy. The Accounting Review 73. p. 19-45, 1998.

ABARBANELL, J.; BUSHEE, B. Financial Statement Analysis, Future Earnings and Stock Prices. Journal of Accounting Research 35, p. 1-24, 1997.

AJINKYA, B.; BHOJRAJ, S.; SENGUPTA, P. The governance role of institutional investors and outside directors on the properties of management earnings forecasts. Journal of Accounting Research 43, p. 343-376, 2005.

ALFORD, A.; JONES J.; LEFTWICH, R.; ZMIJEWSKI, M. The Relative Informativeness of Accounting Disclosures in Different Countries. Journal of Accounting Research 31 (Supplement), p. 183-223, 1993.

ALI, A.; HWANG, L. Country-Specific Factors Related to Financial Reporting and the Value Relevance of Accounting Data. Journal of Accounting Research 38, p. 1-25, 2000.

ANDERSON, C.W. Financial Contracting Under Extreme Uncertainty: an Analysis of Brazilian Corporate Debentures. Journal of Financial Economics 51, p. 45-84, 1999.

ANDERSON, R.; MANSI, S.; REEB, D. Board characteristics, accounting report integrity, and the cost of debt. Journal of Accounting and Economics 37, p. 315-342, 2004.

ARAUJO, A.; FUNCHAL B. Nova Lei de Falências Brasileira e seu papel no desenvolvimento do mercado de crédito. Pesquisa e Planejamento Econômico, 36, p. 209-254, 2006.

ASHBAUGH-SKAIFE, H.; COLLINS, D.W.; LAFOND, R. The effects of corporate governance on firms' credit ratings. Journal of Accounting and Economics 42, p. 203-243, 2006.

BALL, R., BROWN, P. An Empirical Evaluation of Accounting Income Numbers. Journal of Accounting Research 6, p.159-177, 1968.

BALL, R.; A., ROBIN; WU, J. Incentives versus standards: Properties of accounting income in four East Asian Countries. Journal of Accounting and Economics 36, p.235-270, 2003.

BALL, R.; KOTHARI, S. P.; ROBIN, A. The Effect of Institutional Factors on the Properties of Accounting Earnings. Journal of Accounting and Economics 29, p. 1-51, 2000.

BARTH, M.; HUTTON, A. Analyst Earnings Forecast Revisions and the Pricing of Accruals. Review of Accounting Studies 9, p.59-96, 2004.

BEAVER, W.H. Financial Reporting: An Accounting Revolution. 3a. ed., Englewood Cliffs, New Jersey: Prentice Hall, 1998.

BEAVER, W.H. The Information Content of Annual Earnings Announcements. Journal of Accounting Research Supplement 6, p.67-92, 1968.

BEKAERT, G.; HARVEY, C.R.; LUNDBLAD, C. Liquidity and Expected Returns: Lessons from Emerging Markets. Review of Financial Studies, forthcoming <disponível em http://www0.gsb.columbia.edu/faculty/gbekaert/research.html>, Working Paper, 2006.

BERLE, A.; MEANS, G. The modern corporation and private property. Chicago: Commerce Clearing House, 1932.

BERNSTEIN, L.A.; WILD, J.J. Financial Statement Analysis: Theory, Application and Interpretation. New York: McGraw-Hill Irwin, 1997.

BLACK, B.S. Strengthening Brazil's Securities Markets. Working Paper No. 205, Stanford Law School, 2000. 
BORBA, J.A.; MURCIA, F.D. Quantificando as fraudes contábeis sob duas óticas: jornais econômicos e periódicos acadêmicos no período de 2001-2004. In: VII Encontro de Contabilidade do mestrado em ciências contábeis da UERJ, 2005.

BRADSHAW, M.; RICHARDSON, S.; SLOAN, R. Do analysts and auditors use information in accruals? Journal of Accounting Research 39, p.45-74, 2001.

BREALEY, R.A.; MYERS, S.C. Principles of Corporate Finance. 5a. ed. New York: McGrawHill, 2000.

BRIGHAM E.F.; GAPENSKI, L.C.; EHRHARDT, M. C. Administração Financeira: Teoria e Prática. São Paulo: Atlas, 2001.

BRITO, N.R.O. Eficiência informacional fraca de mercados de capitais sob condições de inflação. Revista Brasileira do Mercado de Capitais, Rio de Janeiro, v. 4, n. 10, p. 63-85, 1978.

BROWN, L.D.; CAYLOR, M.L. Corporate Governance and Firm Valuation. Journal of Accounting and Public Policy 25, p.409-434, 2006.

BUSHMAN, R.M.; CHEN, Q.; ENGEL, E.; SMITH, A.J. Financial Accounting Information, Organizational complexity and Corporate Governance Systems. Journal of Accounting and Economics 37, p.167-201, 2004.

BUSHMAN, R.M.; ENGEL, E.; SMITH, A.J. An Analysis of the Relation between the Stewardship and Valuation Roles of Earnings. Journal of Accounting Research 44, p.53-82, 2006.

BUSHMAN, R.M.; SMITH, A.J. Financial Accounting Information and Corporate Governance. Journal of Accounting and Economics 32, p.237-333, 2001.

CHRISTENSEN, J.A.; DEMSKI, J.S. Accounting Theory: An Information Content Perspective. New York: McGraw-Hill Irwin, 2003.

CHRISTENSEN, P.O.; FELTHAM, G.A. Economics of Accounting: Volume I - Information in Markets. Kluwer Academic Publishers, 2003.

CONTADOR, C.R. A hipótese do mercado eficiente e a rentabilidade de ações no Brasil. Revista da ABAMEC, Rio de Janeiro: ABAMEC, v. 7, n. 1, 1973.

COPELAND, T.; KOLLER, T.; MURRIN, J. Valuation: measuring and managing the value of companies. New York: Wiley, 2000.

CORE, J.; HOLTHAUSEN, R.; LARCKER, D. Corporate governance, chief executive officer compensation, and firm performance. Journal of Financial Economics 51, p. 371-406, 1999.

CORE, J.E.; GUAY, W.; RUSTICUS, T. Does Weak Governance Cause Weak Stock Returns? An Examination of Firm Operating Performance and Investors' Expectations. Journal of Finance 61, p.655-687, 2006.

COSTA, N. C. Overreaction in the Brazilian Stock Market. Journal of Banking and Finance 18. p. 633-642, 1994.

COSTA, R.T. Prefácio in TERTUliAnO, F.; PESSOA, I.; AGUIAR, I., AYOUB, R., TRANCANELLA, R., RIOLI, V., (Eds). Full Disclosure: como Aperfeiçoar o Relacionamento das Empresas Abertas com o Mercado de Capitais. São Paulo: Editora Maltese, p. 11-13, 1993.

CREMERS, K.J.M.; NAIR, V.B. Governance mechanisms and equity prices. Journal of Finance 60, p.2859-2894, 2005.

DAINES, R. Does Delaware Law Improve Firm Value? Journal of Financial Economics 62, p. 525-558, 2001. 
DAMODARAN, A. Investment Valuation: Tools and Techniques for Determining the Value of Any Asset. 2nd ed. New York: Wiley, 2002.

DECHOW, P.M. Accounting earnings and cash flows as measures of firm performance: The role of accounting accruals. Journal of Accounting and Economics 18, p.3-42, 1994.

DECHOW, P.M.; DICHEV, I.D. The Quality of Accruals and Earnings: The Role of Accrual Estimation Errors. The Accounting Review 77, p.35-59, 2002.

DECHOW, P.M.; KOTHARI, S.P.; WATTS, R.L. The relation between earnings and cash flows. Journal of Accounting and Economics 25, p.133-168, 1998.

DECHOW, P.M.; SCHRAND, C.M. Earnings Quality. The Research Foundation of CFA Institute, 2004.

DECHOW, P.M.; SLOAN, R.; SWEENEY, A. Causes and Consequences of Earnings Manipulations: an analysis of firms subject to enforcement actions by the SEC. Contemporary Accounting Research 13, p.1-36, 1996.

DEMIRAKOS, E.G.; STRONG, N.C.; WALKER, M. What valuations models do analysts use? Accounting Horizons 18, p.221-240, 2004.

DOIDGE, C.; KAROLYI, A.; LINS, K. V., MILLER, D. P.; STULZ, R. Private Benefits of Control, Ownership, and the Cross-listing Decision. Working Paper, University of Toronto, 2006.

DOIDGE, C.; KAROLYI, A.; STULZ, R. Why do countries matter so much for corporate governance? Journal of Financial Economics 86, p.1-39, 2007.

DOUKAS, J.A.; KIM, C.F.; PANTZALIS, C. A test of the errors-in-expectations explanations of the value/glamour stock returns performance: evidences from analysts forecasts. Journal of Finance 57. 2002, p. 2143-2165.

DURNEV, A.; KIM, E.H. To Steal or Not to Steal: Firm Attributes, Legal Environment, and Valuation. Journal of Finance 60, p. 1461-1493, 2005.

EID, W. Valor x Crescimento: Uma análise empírica da relação risco x retorno nas carteiras de ações da Bovespa. Working Paper, NPP - núcleo de pesquisas e publicações da FGV/EAESP, 1999.

FAMA, E.F. Efficient capital markets: a review of theory and empirical work. Journal of Finance 25. p. 383-417, 1970.

FAMA, E.F. Foundations of Finance. New York: Basic Books, 1976.

FAMA, E.F.; FRENCH, K.R. The cross section of expected stock returns. Journal of Finance 47. p. 427-465, 1992.

FAMA, E.F.; FRENCH, K.R. Common risk factors in the returns on stocks and bonds. Journal of Financial Economics 33, p. 3-56, 1993.

FAMA, E.F.; FRENCH, K.R. Size and book-to-market factors in earnings and returns. Journal of Finance 50. p. 131-155, 1995.

FAMA, E.F.; FRENCH, K.R. Multifactor explanations of asset pricing anomalies. Journal of Finance 51. 1996, p. 55-84, 1996.

FELTHAM, G.; OHLSON, J. Valuation and clean surplus accounting for operating and financial activities. Contemporary Accounting Research 11, p.689-731, 1995. 
FINANCIAL ACCOUNTING STANDARDS BOARD. Statement of Financial Accounting Standards Concepts No. 1: Objectives of Financial Reporting by BusinessEnterprises. Norwalk: Fasb, 1978.

FRANCIS, J.; OLSSON, P.; OSWALD, D. Comparing accuracy and explainability of dividend, free cash flow and abnormal earnings equity value estimates. Journal of Accounting Research 38, p.45-70, 2000.

FRANKEL, R., LEE, C. Accounting valuation, market expectation, and cross-sectional stock returns. Journal of Accounting and Economics 25, p.283-319, 1998.

GAZETA MERCANTIL. O Mercado paga pouco para ter direito a voto. São Paulo, p. C-1, 22 de Dezembro, 2000.

GIROUX, G. Earnings Magic and the Unbalance Sheet: The search for Financial Reality. New Jersey: John Wiley \& Sons, 2006.

GOMPERS, P.; ISHII, J.; METRICK, A. Corporate governance and equity prices. Quarterly Journal of Economics 118, p.107-155, 2003.

GORGA, E.C.R. Does Culture Matter for Corporate Governance? A Case Study of Brazil. Working Paper 257, Stanford Law School, 2003.

GRAHAM, B.; DODD, D.L. Security Analysis. McGraw-Hill, New York, 1934.

GUAY, W. Discussion of Value Investing: The Use of Historical Financial Statement Information to Separate Winners from Losers. Journal of Accounting Research 38, p. 43-51, 2000.

HAQUE, M.; HASSAN, M.K.; VARELA, O. Stability, volatility, risk premiums and predictability in Latin American emerging stock markets. Quarterly Journal of Business and Economics 40, p.23-44, 2001.

HARVEY, C.R. Predictable risk and returns in emerging markets. Review of Financial Studies 8, p. 773-816, 1995.

IMHOFF, E.A. Accounting Quality, Auditing, and Corporate Governance. Accounting Horizons (Supplement), p.117-128, 2003.

INTERNATIONAL ACCOUNTING STANDARDS BOARD. Framework for the Preparation and Presentation of Financial Statements. Financial Reporting Standards including International Accounting Standards and Interpretations as at 1 January 2007, p. 31-56, London: IASB, 2007.

IUDÍCIBUS, S.; LOPES, A.B. Teoria Avançada da Contabilidade. São Paulo: Atlas, 2004.

IUDÍCIBUS, S.; MARTINS, E.; GELBCKE, E.R. Manual de Contabilidade das Sociedades por Ações. 7a. ed. São Paulo: Atlas, 2007.

JENSEN, M.C.; MECKLING, W.H. Theory of the firm: managerial behavior, agency costs and ownership structure. Journal of Financial Economics 3, p. 305-360, 1976.

KANAGARETNAM, K.; LOBO, G.J.; WHALEN, D.J. Does good corporate governance reduce information asymmetry around quarterly earnings announcements? Journal of Accounting and Public Policy 26, p. 497-522, 2007.

KARAMANOU, I.; VAFEAS, N. The association between corporate boards, audit committees, and management earnings forecasts: An empirical analysis. Journal of Accounting Research 43, p. 453-486, 2005. 
KAREMERA, D.; OJAH K.; COLE, J.A. Random walks and market efficiency tests: Evidence from emerging equity markets. Review of Quantitative Finance and Accounting 13, p. 171-188, 1999.

KOTHARI, S.P. Capital Markets Research in Accounting. Journal of Accounting and Economics 31, p. 105-231, 2001.

LA PORTA, R; LAKONISHOK, J; SHLEIFER, A.; VISHNY, R. Good news for value stocks: Further evidence on market efficiency. Journal of Finance 52, p. 859-874, 1997a.

LA PORTA, R.; LOPES-DE-SILANEZ, F.; SHLEIFER, A; VISHNY, R. Legal Determinants of External Finance. Journal of Finance 52, p.1131-1150, $1997 \mathrm{~b}$.

LA PORTA, R; LOPEZ-DE-SILANES, F.; SHLEIFER, A.; VISHNY, R. Investor Protection and Corporate Valuation. Journal of Finance 57, p. 1147-1170, 2002.

LAKONISHOK, J.; SHLEIFER, A.;VISHNY R. Contrarian Investments, extrapolation and risk. Journal of Finance 49, p. 1541-1578, 1994.

LAMBERT, R.; LEUZ, C.; VERRECCHIA, R. Accounting information, disclosure, and the cost of capital. Journal of Accounting Research 45, p. 385-420, 2007.

LEAL, R.P.C.; SILVA, A.C. Corporate Governance Index, Firm Valuation and Performance in Brazil. Revista Brasileira de Finanças 3, p. 1-18, 2005.

LEE, C. Accounting-based valuation: a commentary. Accounting Horizons 13, p. 413-425, 1999.

LEV, B.; THIAGARAJAN, R. Fundamental Information Analysis. Journal of Accounting Research 31, p. 190-214, 1993.

LEV, B.; THIAGARAJAN, R. Fundamental Information Analysis. Journal of Accounting Research 31, p. 190-214, 1993.

LIMA, H.S. Um estudo das anomalias no apreçamento de ações no mercado brasileiro utilizando o modelo de quatro fatores. Dissertação [Mestrado em Engenharia de Produção]. Rio de Janeiro - Pontifícia Universidade Católica do Rio de Janeiro, 2003.

LIU, J.; NISSIM, D.; THOMAS, J. Equity Valuation using Multiples. Journal of Accounting Research 40, p. 35-172, 2002.

LOBO, G.; ZHOU, J. Disclosure quality and earnings management. Asia-Pacific Journal of Accounting and Economics 8, p. 1-20, 2001.

LOPES, A.B. A Relevância da informação contábil para o mercado de capitais: o modelo de Ohlson aplicado à Bovespa. Tese (Doutorado) - Faculdade de Economia, Administração e Contabilidade da Universidade de São Paulo, 2001.

LOPES, A.B. Financial Accounting in Brazil: an Empirical Examination. Latin American Business Review 6, p.45-68, 2005.

LOPES, A.B.; MARTINS, E. Teoria da Contabilidade: uma nova abordagem. São Paulo: Atlas, 2005.

LOPES, A.B.; WALKER, M. Firm-level incentives and the informativeness of accounting reports: an experiment in Brazil. Working Paper (disponível em www.ssrn.com), 2008.

LUNDHOLM, R.; O'KEEFE, T. Reconciling Value Estimates from the Discounted Cash Flow Model and the Residual Income Model. Contemporary Accounting Research 18, p.311-335, 2001.

LUZ, A. C. C. A Nova Lei das S.A. e a Governança Corporativa. Discurso no International Institute of Research (IIR). São Paulo, Dezembro, 2000. 
MASHRUWALA, C.; RAJGOPAL, S.; SHEVLIN, T. Why is the accrual anomaly not arbitraged away? The role of idiosyncratic risk and transaction costs. Journal of Accounting and Economics 42, p. 3-33, 2006.

MARTINEZ, A.L. Gerenciamento dos resultados contábeis: Estudo empírico das companhias abertas brasileiras. Tese (Doutorado) - Faculdade de Economia, Administração e Contabilidade da Universidade de São Paulo, 2001.

MARTINS, E. (Org.) Avaliação de empresas: Da mensuração Contábil à Econômica. São Paulo: Atlas, 2001.

MARTINS, E. Contabilidade Versus Fluxo de Caixa. Caderno de Estudos 20, p. 9-17, 1999.

MARTINS, G. A. Manual para elaboração de monografias e dissertações. $2^{\mathrm{a}}$ edição. São Paulo: Atlas, 2000.

MOHANRAN. S. Separating Winners from Losers among Low Book-to-Market Stocks using Financial Statement Analysis. Review of Accounting Studies 10, p. 133-170, 2005.

MORCK, R.; YEUNG, B.; YU, W. Why do emerging markets have synchronous stock price movements? Journal of Financial Economics 58, p. 215-260, 2000.

MYERS, S.C. The capital structure puzzle. Journal of Finance 39, p. 572-592, 1984.

MUNIZ, C. J. Testes preliminares de eficiência do mercado de ações brasileiro. Revista Brasileira do Mercado de Capitais. Rio de Janeiro: Instituto Brasileiro de Mercado de Capitais, v. 6, n. 16, p. 80-94, 1980.

NOBES, C. Towards a General Model of the Reasons for International Differences in Financial Reporting. Abacus, September 34, p. 162-187, 1998.

OHLSON, J.A. Discussion of an analysis of Historical and Future-Oriented Information in Accounting-Based Security Valuation Models. Contemporary Accounting Research 16, Issue 2, p.381-384, 1999.

OHLSON, J.A. Discussion of Residual Income and Value-Creation: The Missing Link. Review of Accounting Studies 7, p.247-251, 2002.

OHLSON, J.A. Earnings, book values and dividends in equity valuation. Contemporary Accounting Research 11, p.661-687, 1995.

OHLSON, J.A. Earnings, Book Values and Dividends in Equity Valuation: An Empirical Perspective. Contemporary Accounting Research 18, p.107-120, 2001.

OHLSON, J.A. On accounting based valuation formulae. Review of Accounting Studies 10, p.323-347, 2005.

OHLSON, J.A. ; ZHANG, X-J. On the Theory of Forecast Horizon in Equity Valuation. Journal of Accounting Research 37, p.437-449, 1999.

OHLSON, J.A.; GAO, Z. Earnings, Earnings Growth and Value. Foundations and Trends® in Accounting 1, Hanover: now Publishers, 2006.

OHLSON, J.A.; JUETTNER-NAUROTH, B.E. Expected EPS and EPS Growth as determinants of Value. Review of Accounting Studies 10, p.349-365, 2005.

OHLSON, J.A.; LOPES, A.B. Accounting based valuation formulae. Brazilian Business Review 4, p.95-102, 2007.

OHLSON, J.A.; ZHANG, X-J. Accrual Accounting and Equity Valuation. Journal of Accounting Research 36, p.85-111, 1998. 
OJAH, K.; KAREMERA, D. Random walks and market efficiency tests of Latin American Emerging equity markets. Financial Review 34, p. 57-72, 1999.

ORTIZ, G. Recent Emerging Market Crises: What Have We Learned? Basel Switzerland, 2002.

OU, J.; PENMAN, S. Accounting Measures, Price-Earnings Ratio and the Information Content of Security Prices. Journal of Accounting Research 27, p. 111-143, 1989b.

OU, J.; PENMAN, S. Financial statement analysis and the prediction of stock returns. Journal of Accounting and Economics 11, p. 295-329, 1989a.

PALEPU, K.G.; HEALY, P.G.; BERNARD, V. L. Business Analysis and Valuation: Using Financial Statements. 3rd ed. Ohio: South-Western College Publishing, 2004.

PATTON, W.A.; LITTLETON, A.C. An Introduction to Corporate Accounting Standards, American Accounting Asociation, 1940.

PAULO, E.; CUNHA, J.V.A.; ALENCAR, R.C.; MARTINS, E. A prática dos peritos contadores na apuração de haveres. Revista Brasileira de Gestão de Negócios 8, p. 24-36, 2006.

PENMAN, S.H. A synthesis of equity valuation techniques and the terminal value calculation of the dividend discount model. Review of Accounting Studies 2, p. 303-323, 1997.

PENMAN, S.H. Financial Statements Analysis and Security Valuation. 3rd ed. New York: McGraw-Hill, 2007.

PENMAN, S.H. On Comparing Cash Flow and Accrual Accounting Models for Use in Equity Valuation: A Response to Lundholm and O'Keefe (CAR, Summer 2001). Contemporary Accounting Research 18, p.681-692, 2001.

PENMAN, S.H.; RICHARDSON, S.A.; TUNA, I. The book-to-price effect in stock returns: accounting for leverage. Journal of Accounting Research 45, p. 427-467, 2007.

PENMAN, S.H.; SOUGIANNIS, T. A Comparison of Dividend, Cash Flow, and Earnings Approaches to Equity Valuation. Contemporary Accounting Research 15, p.343-383, 1998.

PEROBELLI, F.F.C.; NESS, W. Reações do mercado acionário a variações inesperadas nos lucros das empresas: um estudo sobre a eficiência informacional no mercado brasileiro. In: $24^{\circ}$ ENANPAD, Anais... Florianópolis/SC, 2000.

PINCUS, M; RAJGOPAL, S; VENKATACHALAM, M. The Accrual Anomaly: International Evidence. The Accounting Review 82, p. 169-203, 2007.

PIOTROSKI, J.D. Discussion of Separating Winners from Losers among Low Book-to-Market Stocks using Financial Statement Analysis. Review of Accounting Studies 10, p. 171-184, 2005.

PIOTROSKI, J.D. Discussion of The book-to-price effect in stock returns: accounting for leverage. Journal of Accounting Research 45, p. 469-479, 2007.

PIOTROSKI, J.D. Value Investing: The Use of Historical Financial Statement Information to Separate Winners from Losers. Journal of Accounting Research 38, p. 1-41, 2000.

PLATIN, G.; SAPRA, H.; SHIN, H. Marking-to-market: panacea or pandora's box? Journal of Accounting Research, forthcoming. <disponível em http://www.princenton.edu/ hsshin/ working.htm>, Working Paper, 2007.

PROCIANOY, J. L.; ANTUNES, M.A. Os efeitos das decisões de investimento das firmas sobre os preços de suas ações no mercado de capitais. In: 25 ENANPAD, Anais...Campinas/SP, 2001.

RATNER, M.; LEAL, R. P. C. Tests of Technical Trading Strategies in the Emerging Equity Markets of Latin America and Asia. Journal of Banking and Finance 23, p. 1887-1905, 1999. 
REVSINE, L.; COLLINS, D.W.; JOHNSON, W.B. Financial Reporting and Analysis. New Jersey: Prentice Hall, 1999.

ROCHMAN, R.R.; EID, W. Fundos de Investimento Ativos e Passivos no Brasil: Comparando e Determinando os seus Desempenhos. In: 30NANPAD, Anais...Salvador/BA, 2006.

ROSENBERG, B.; REID, K.; LANSTEIN, R. Persuasive evidence of market inefficiency. Journal of Portfolio Management 11. 1984, p. 9-17.

ROSS, S. The Economic Theory of Agency: The principal's problem. The American Economic Review 63, p. 134-139, 1973.

ROSS, S.; WESTERFIELD, R.; JAFFE, J. Administração Financeira. São Paulo: Atlas, 1995.

SCHIEHLL, E. O efeito da divulgação das demonstrações contábeis no mercado de capitais brasileiro: um estudo sobre a variação no preço das ações. In: $20^{\circ}$ ENANPAD, Anais...Angra dos Reis/RJ, 1996.

SHLEIFER, A.; VISHNY, R. A survey of corporate governance. Journal of Finance 52, p. 737783, 1997.

SIEGEL, S. Nonparametric statistics for the behavioral sciences. New York: McGraw-Hill, 1956.

SLOAN, R. Do stock prices fully reflect information in accruals and cash flows about future earnings? The Accounting Review 71, p.289-315, 1996.

SLOAN, R. Financial Accounting and Corporate Governance: a Discussion. Journal of Accounting and Economics 32, p.335-347, 2001.

SMITH, C.; WARNER, J. On financial contracting: an analysis of bond covenants. Journal of Financial Economics 7, p. 117-161, 1979.

SOFFER, L.; SOFFER, R. Financial Statement Analysis: A Valuation Approach. New Jersey: Prentice Hall, 2003.

SPENCE, M.; ZECKHAUSER, R. Insurance, Information and Individual Action. American Economic Review 61, p. 380-387, 1971.

STANDARD \& POOR'S. Standard \& Poor's Corporate Governance Scores: Criteria, Methodology and Definitions. McGraw-Hill Companies, Inc., New York, 2002.

TIROLE, J. The Theory of Corporate Finance. New Jersey: Princeton University Press, 2006.

TURNER, L.E.; WEIRICH, T.R. A closer look at financial statement restatements: analyzing the reasons behind the trend. The CPA Journal, December, 2006.

WELKER, M. Disclosure policy, information asymmetry, and liquidity in equity markets. Contemporary Accounting Research 11, p. 801-827, 1995.

WHITE, G.I.; SONDHI, A.C.; FRIED, D. The Analysis and Use of Financial Statements. 3rd ed. New York: John Wiley \& Sons, 2003.

WOOLDRIDGE, J.M. Econometric analysis of cross section and panel data. Massachusetts: MIT press, 2002.

XIE, H. The mispricing of abnormal accruals. The Accounting Review 76, p.357-373, 2001. 


\section{APÊNDICES}

APÊNDICE A - Apresentação das questões elaboradas para a apuração do índice Brasileiro de Governança Corporativa (BCGI).

APÊNDICE B - Demonstração da associação teórica positiva entre aumento nos níveis de governança corporativa e preço das ações - Proposição 3.

APÊNDICE C - Demonstração da função que faz a ligação entre o preço de uma ação, o lucro anormal e o parâmetro de persistência do lucro anormal - equação (13).

APÊNDICE D - Características das empresas por quintil do índice PL/P e do BCGI no período de 1997-2004.

APÊNDICE E - Avaliação da robustez e da performance anual da estratégia por grupo no período de 1997-2004. 


\section{APÊNDICE A}

\section{$\underline{\text { Questionário do índice Brasileiro de Governanca Corporativa (BCGI) }}^{59}$}

\section{I - DISCLOSURE}

1. A empresa publica suas demontrações contábeis dentro do período requerido?

2. A empresa divulga suas demonstrações contábeis de acordo com padrões internacionais de contabilidade (US-GAAP ou IFRS)?

3. A empresa é auditada por uma das big 4 firmas de auditoria?

\section{II - COMPOSIÇÃO E FUNCIONAMENTO DO CONSELHO}

4. O presidente do Conselho de Administração e o CEO são a mesma pessoa?

5. O Conselho de Administração é composto principalmente por membros externos à empresa?

6. O tamanho do Conselho de Administração está entre 5 e 9 membros como sugerido pelo Instituto Brasileiro de Governança Corporativa?

7. Os membros do Conselho de Administração têm mandato consecutivo de um ano, conforme sugerido pelo Instituto Brasileiro de Governança Corporativa?

8. A empresa tem um comitê de auditoria permanente?

\section{III - ESTRUTURA ACIONÁRIA E CONTROLE}

9. Os acionistas controladores têm menos do que $50 \%$ das ações com direito a voto?

10. O percentual das ações votantes é maior que $80 \%$ do capital total?

11. O índice entre direitos sobre o fluxo de caixa e direitos sobre os votos é maior do que 1 ?

12. O free-float é maior ou igual ao requerido pela Bovespa no novo Mercado (25\%)?

\section{IV - DIREITOS DOS ACIONISTAS}

13. O estatuto da empresa estabelece algum mecanismo de arbitragem para resolver conflitos?

14. O estatuto da empresa estabelece algum direito adicional aos requeridos por lei?

15. A empresa tem tag along além do requerido por lei?

\footnotetext{
${ }^{59}$ Baseado em Lopes e Walker (2008). Todas as respostas foram obtidas de fontes públicas de informação. Este questionário não foi enviado às empresas. Um valor de 1 foi dado aos aspectos considerados como de boa governança e 0 foi dado em caso contrário. As notas das empresas variam de 0 a 15 . Posteriormente estas notas foram padronizadas para ficar no intervalo de 0 a 1 . As respostas foram obtidas junto à todas companhias abertas brasileiras listadas em Bolsa para os anos de 1998, 2000, 2002 e 2004. Este índice foi primeiramente desenvolvido por Leal e Silva (2005).
} 


\section{APÊNDICE B}

Demonstração da Proposição 3:

Sabendo-se que:
i) $P_{0}=\frac{\tilde{x}_{1}}{r} \times\left[\frac{g_{s}-L T G}{r-L T G}\right]$
ii) $g_{s}=\frac{\tilde{x}_{2}-\tilde{x}_{1}}{\tilde{x}_{1}}+\frac{r \times d_{1}}{\tilde{x}_{1}}$
iii) $\tilde{x}_{t+1+\tau}=\left(E B I T_{t+1+\tau}-k_{d_{t+1+\tau}}\left(\operatorname{Debt}_{t+1+\tau}\right)\right)(1-T)$
iv) $k_{d}=\frac{1-p(e(g))}{p(e(g))}\left[1-v_{\text {insolv }}^{u}\right]$
v) $r>L T G$
vi) $0<r<1$

Tem-se:

$$
\begin{aligned}
& \frac{\partial P_{0}}{\partial \tilde{x}_{1}}=\frac{1+L T G}{L T G\left(r-r^{2}\right)}>0 \\
& \frac{\partial P_{0}}{\partial \tilde{x}_{2}}=\frac{1}{r(r-L T G)}>0 \\
& \frac{\partial \tilde{x}_{1}}{\partial g}=\frac{a\left(D E B T_{1}\right)\left[-1+v_{\text {insolv }}^{u}\right][-1+T] p^{\prime}(e(g))}{p(e(g))^{2}}>0 \\
& \frac{\partial \tilde{x}_{2}}{\partial g}=\frac{a\left(D E B T_{2}\right)\left[-1+v_{\text {insolv }}^{u}\right][-1+T] p^{\prime}(e(g))}{p(e(g))^{2}}>0 \\
& \therefore \frac{\partial P_{0}}{\partial g}>0 .
\end{aligned}
$$




\section{APÊNDICE C}

Demonstração de (13):

Sabendo-se que (modelo RIV):

i) $P_{t}-b_{t}=\sum_{\tau=1}^{\infty} R^{-\tau} E_{t}\left[x_{t+\tau}^{a}\right]$

ii) $x_{t+1}^{a}=\omega x_{t}^{a}+v_{t}+\varepsilon_{1 t+1}$

$v_{t+1}=\delta v_{t}+\varepsilon_{2 t+1}$

Assume-se uma solução linear do tipo $s_{t}=\alpha_{1} x_{t}^{a}+\alpha_{2} v_{t}=P_{t}-b_{t}=\sum_{\tau=1}^{\infty} R^{-\tau} E_{t}\left[x_{t+\tau}^{a}\right]$ e resolve-se o sistema para $\alpha_{1}$ e $\alpha_{2}$. Para isso, deve-se considerar que:

$$
\begin{aligned}
& E_{t}\left[P_{t+1}-b_{t+1}+x_{t+1}^{a}\right]= \\
& \sum_{\tau=t+1}^{\infty} R^{-\tau} E_{t}\left[x_{\tau+1}^{a}\right]+E_{t}\left[x_{\tau}^{a}\right]=R \cdot E_{t}\left[P_{t}-b_{t}\right]^{60} \\
& \therefore E_{t}\left[s_{t+1}+x_{t+1}^{a}\right]=R s_{t}
\end{aligned}
$$

Assim, o lado esquerdo da equação acima pode ser expresso por:

$$
\begin{aligned}
& E_{t}\left[\alpha_{1} x_{t+1}^{a}+\alpha_{2} \tilde{v}_{t+1}+x_{t+1}^{a}\right] \\
= & E_{t}\left[\left(\alpha_{1}+1\right) x_{t+1}^{a}+\alpha_{2} v_{t+1}\right] \\
= & \left(\alpha_{1}+1\right)\left(\omega \tilde{x}_{t}^{a}+\tilde{v}_{t}\right)+\alpha_{2} \delta \tilde{v}_{t} \\
= & \left(\alpha_{1}+1\right) \omega x_{t}^{a}+\left(\alpha_{1}+1+\alpha_{2} \delta\right) v_{t}
\end{aligned}
$$

O lado direito da equação pode ser expresso por $R \alpha_{1} x_{t}^{a}+R \alpha_{2} v_{t}$.

${ }^{60} \mathrm{Em} \mathrm{t}=0$, tem-se:

$$
x_{2}^{a} R^{-1}+x_{3}^{a} R^{-2}+x_{3}^{a} R^{-3}+\ldots+x_{1}^{a}=R\left(x_{1}^{a} R^{-1}+x_{2}^{a} R^{-2}+x_{3}^{a} R^{-3}+x_{3}^{a} R^{-4}+\ldots\right)=R \sum_{\tau=t}^{\infty} R^{-\tau} E_{t}\left[x_{\tau}^{a}\right]
$$


Igualando $\alpha_{1}$ e $\alpha_{2}$ no lado esquerdo e direito da equação acima, obtém-se:

$\left(\alpha_{1}+1\right) \omega=R \alpha_{1}$

$\alpha_{1}+1+\alpha_{2} \delta=R \alpha_{2}$

Assim, pode-se resolver $\alpha_{1}$ e $\alpha_{2}$ em função dos parâmetros $\omega$ e $\delta$. Isto resulta em:

i) $\alpha_{1}=\omega /(R-\omega)$

ii) $\alpha_{2}=R /(R-\omega)(R-\delta)$.

Assim tem-se que $P_{t}=b_{t}+\alpha_{1} x_{t}^{a}+\alpha_{2} v_{t}$, onde $\alpha_{1}=\omega /(R-\omega)$ e $\alpha_{2}=R /(R-\omega)(R-\delta)$. 


\section{APÊNDICE D}

Médias das características da empresa por quintil do índice PL/P e do BCGI no período de 1997-2004

\begin{tabular}{|c|c|c|c|c|}
\hline \multicolumn{5}{|c|}{ Painel A } \\
\hline $\mathrm{PL} / \mathrm{P}$ & 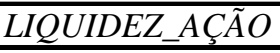 & DÍVIDA_CP & ESTRUT_CAP & Mkt. Cap. \\
\hline 1 (baixo) & 0,5403 & 0,4623 & 0,6501 & 3.879 .768 \\
\hline 2 & 0,4608 & 0,4674 & 0,5942 & 2.825 .480 \\
\hline 3 & 0,1790 & 0,5001 & 0,5538 & 851.120 \\
\hline 4 & 0,1239 & 0,5428 & 0,5437 & 451.956 \\
\hline 5 (alto) & 0,0840 & 0,5651 & 0,5453 & 378.980 \\
\hline Total & 0,2787 & 0,5064 & 0,5776 & 1.685 .531 \\
\hline \multicolumn{5}{|c|}{ Painel B } \\
\hline BCGI & LIQUIDEZ_AÇÃO & DÍVIDA_CP & ESTRUT_CAP & Mkt. Cap. \\
\hline 1 (baixo) & 0,0861 & 0,5512 & 0,6138 & 534.484 \\
\hline 2 & 0,1189 & 0,5406 & 0,5490 & 823.838 \\
\hline 3 & 0,3238 & 0,5130 & 0,5693 & 1.658 .949 \\
\hline 4 & 0,5257 & 0,4568 & 0,5565 & 2.839 .301 \\
\hline 5 (alto) & 0,5356 & 0,4452 & 0,5989 & 3.794 .226 \\
\hline Total & 0,2808 & 0,5088 & 0,5760 & 1.689 .008 \\
\hline
\end{tabular}

. LIQUIDEZ_AÇÃO - média do índice representativo da liquidez das ações na Bovespa. Quanto maior o valor, mais líquida a ação. Calculado pela seguinte formula: $100(p . P) \sqrt{ }(n . N / v . V)$, onde p é o número de dias em que houve pelo menos um negócio com a ação dentro do período escolhido, $\mathrm{P}$ é número total de dias do período escolhido, n é o número negócios com a ação dentro do período escolhido, $\mathrm{N}$ é o numero de negócios com todas as ações dentro do período escolhido, v é o volume em dinheiro com a ação dentro do período escolhido e V é o volume em dinheiro com todas as ações dentro do período escolhido.

. DÍVIDA_CP - média do índice de dívida de curto prazo dividida pelo endividamento de longo prazo no final do ano.

. ESTRUT_CAP - média da relação entre o endividamento total da empresa e o total de recursos (capital próprio e capital de terceiros) no final do ano.

Mkt. Cap. (R\$ mil) - média do preço da ação no final do ano multiplicado pelo número de ações da empresa no mesmo período. 


\section{APÊNDICE E}

Performance anual da estratégia por grupo no período de 1997-2004

Retorno de 1 ano ajustado pelo mercado (RET_AJ) detalhado para cada ano da aplicação da estratégia para as carteiras de empresas com Alto BrF_SCORE, Baixo BrF_SCORE e o conjunto total de empresas. O painel A apresenta as estatísticas para todas as empresas da amostra, o painel B para as empresas com alto PLP, o painel C para as empresas de baixo BCGI e o painel D apresenta os resultados para o grupo de empresas com alto PL/P e baixo BCGI.

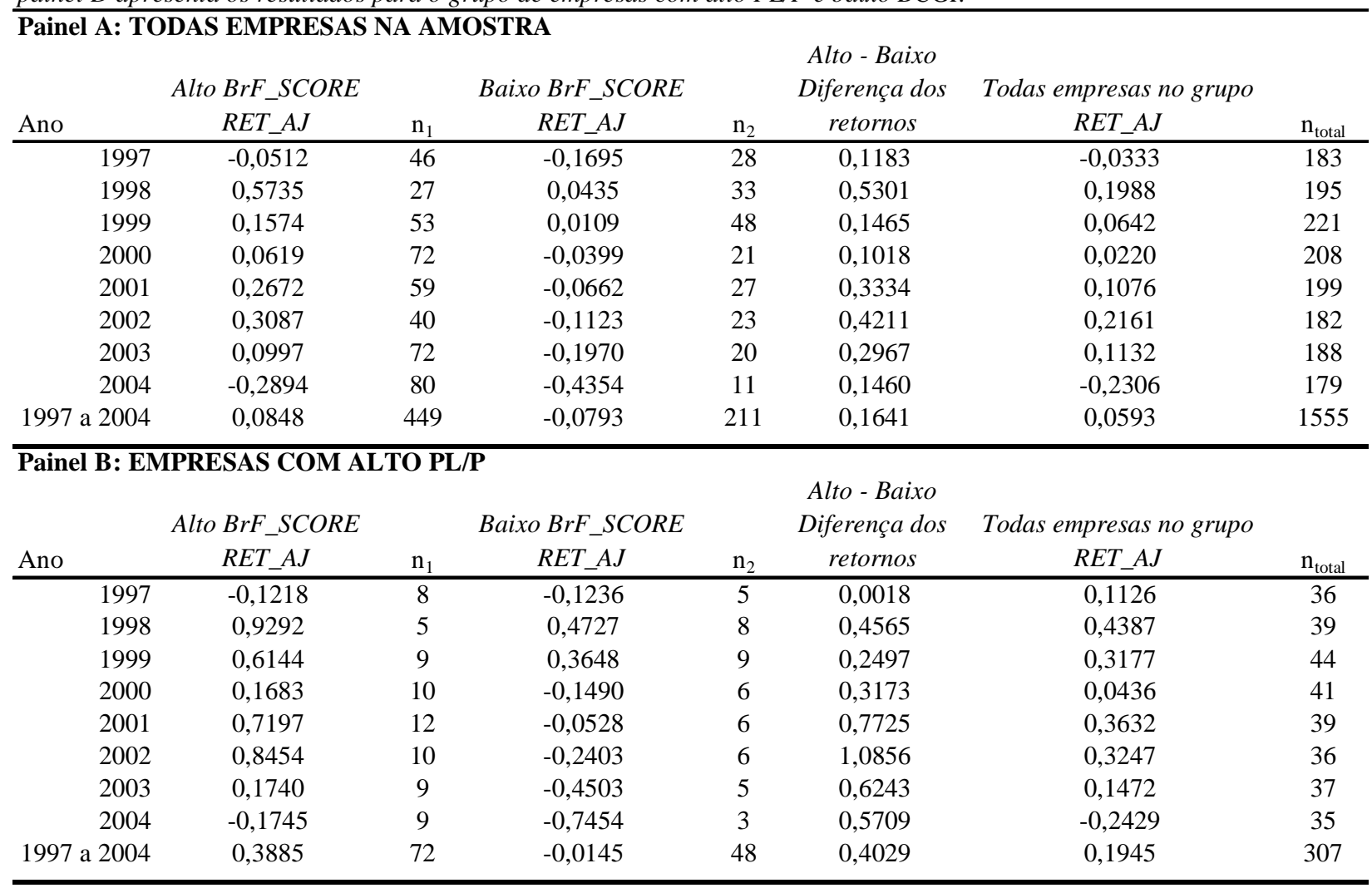

Painel C: EMPRESAS COM BAIXO BCGI

\begin{tabular}{|c|c|c|c|c|c|c|c|}
\hline Ano & $\begin{array}{c}\text { Alto BrF_SCORE } \\
\text { RET_AJ } \\
\end{array}$ & $\mathrm{n}_{1}$ & $\begin{array}{c}\text { Baixo BrF_SCORE } \\
\text { RET_AJ } \\
\end{array}$ & $\mathrm{n}_{2}$ & $\begin{array}{c}\text { Alto - Baixo } \\
\text { Diferença dos } \\
\text { retornos }\end{array}$ & $\begin{array}{c}\text { Todas empresas no grupo } \\
\text { RET_AJ }\end{array}$ & $\mathrm{n}_{\text {total }}$ \\
\hline 1997 & $-0,1476$ & 7 & $-0,0167$ & 7 & $-0,1309$ & $-0,0517$ & 37 \\
\hline 1998 & 0,8576 & 8 & $-0,2987$ & 14 & 1,1562 & 0,0704 & 54 \\
\hline 1999 & 0,2518 & 11 & $-0,4012$ & 5 & 0,6530 & 0,1348 & 46 \\
\hline 2000 & 0,3673 & 13 & 0,2199 & 5 & 0,1473 & 0,2473 & 43 \\
\hline 2001 & 0,4885 & 11 & $-0,1514$ & 5 & 0,6399 & 0,3094 & 40 \\
\hline 2002 & 0,3746 & 10 & $-0,2975$ & 7 & 0,6721 & 0,0937 & 50 \\
\hline 2003 & 0,1482 & 9 & $-0,5143$ & 6 & 0,6625 & 0,0414 & 39 \\
\hline 2004 & $-0,2768$ & 12 & $-0,5902$ & 6 & 0,3134 & $-0,3370$ & 41 \\
\hline 1997 a 2004 & 0,2531 & 81 & $-0,2667$ & 55 & 0,5199 & 0,0674 & 350 \\
\hline
\end{tabular}

Painel D: EMPRESAS COM BAIXO BCGI E ALTO PL/P

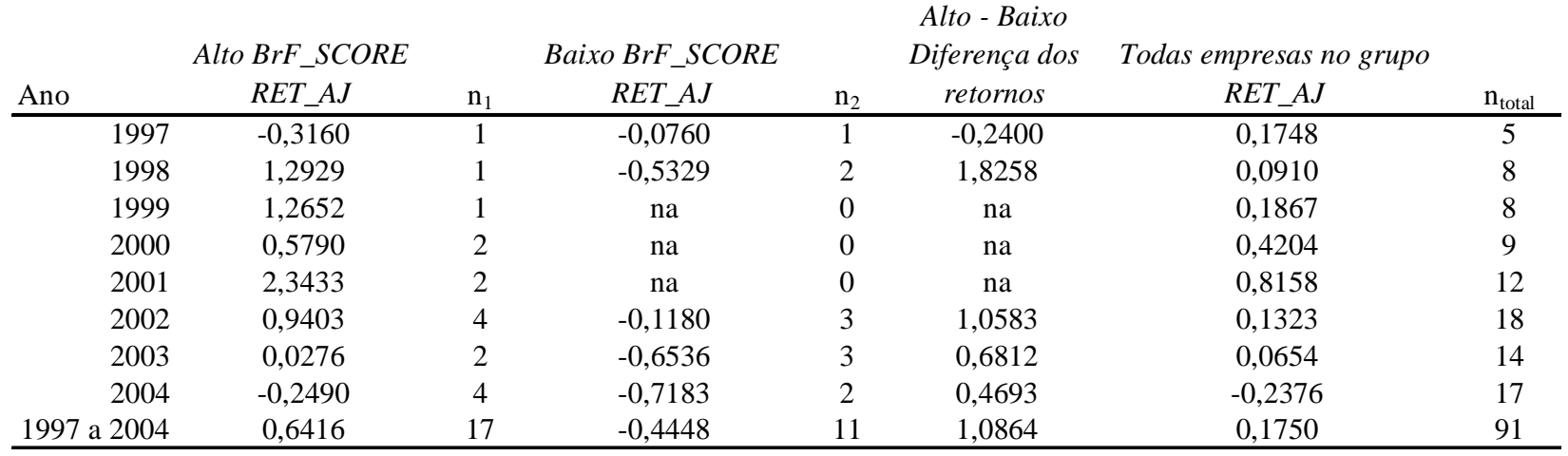

